\title{
DOS TRANSPLANTES JURÍDICOS ÀS TRADUÇÕES JURÍDICAS: A GLOBALIZAÇÃO DO PLEA BARGAINING E A TESE DA AMERICANIZAÇÃO DO PROCESSO PENAL ${ }^{1}$
}

FROM LEGAL TRANSPLANTS TO LEGAL TRANSLATIONS: THE GLOBALIZATION OF PLEA BARGAINING AND THE AMERICANIZATION THESIS IN CRIMIN AL PROCEDURE

\author{
Máximo Langer ${ }^{2}$ \\ Universidade da Califórnia - EUA
}

1 Texto Original: LANGER, Maximo. From Legal Transplants to Legal Translations: The Globalization of Plea Bargaining and the Americanization Thesis in Criminal Procedure". In Harvard International Law Journal. v. 45. n. 01, 2004. p. 01-65. Tradução de Ricardo Jacobsen Gloeckner e Frederico C. M. Faria.

2 Professor de direito da Universidade da Califórnia, Los Angeles - UCLA, Doutor em Ciências Jurídicas da Universidade de Harvard, e Advogado da Universidade de Buenos Aires. Eu gostaria de agradecer a Gianmaria Ajani, Bill Alford, Arthur Applbaum, Tal Bem-Shachar, Scott Cummings, Mirjan Damaška, Sharon Dolovich, Vic Fleisher, Stephen Gardbaum, Latonia Haney, Alon Harel, Ben Hett, Duncan Kennedy, Gia Lee, Alejandro Lorite, Stefano Maffei, Bill McGovern, Martin O’Neill, Sara Olack, Eric Orts, Randy Peeremboom, Kal Raustiala, Arthur Rosett, Gary Rowe, Yoav Sapir, Hani Sayed, Roy Schondorf, Patrick Shin, David Sklansky, Carol Steiker, Richard Streinberg, Bill Stuntz, Lloyd Weinreb, Adam Winkler e os participantes do workshop da Faculdade de Direito da Universidade da Califórnia, Los Angeles, na Conferência SJD/JSD/PhD 2002 na Escola de Direito de Harvard, e na Conferência "Direito e Desenvolvimento Econômico: críticas e além", organizado pelo Centro de Pesquisa de Direito Europeu, na Escola de Direito de Harvard, pelos valiosos comentários sobre as versões preliminares. Eu gostaria especialmente de agradecer a Carol Steiker, Mirjan Damaška, Phil Heymann, Duncan Kennedy, David Sklansky e à Escola de Direito da Universidade da California, Los Angeles, pelo encorajamento e apoio. Guillermo Bleichmar, Janet Halley, Esther Liberman e Doris Sommer deram-me valiosos conselhos bibliográficos nos estudos de tradução. Joanne Jackson e Satyanand Satyananayana fizeram um ótimo trabalho de editoração. Jason Kleiman providenciou um valoroso trabalho de assistência. Eu também reconheço agradecidamente o apoio da Bolsa Byse na Escola de Direito de Harvard, o Centro Para Ética e Profissões de Harvard, a Organização dos Estados Americanos e o Centro Rockefeller de Estudos Latino-Americanos da Universidade de Harvard. Myriam Hess, Bem Hett e Laura Elbert me ajudaram com alguns textos alemães. É claro, quaisquer erros são de minha responsabilidade. 


\section{Resumo}

Este artigo analisa a tese da americanização no processo penal. De acordo com a versão forte desta tese, o sistema jurídico norte-americano se tornou o mais influente sistema no mundo e, como consequência, um número considerável de sistemas jurídicos acabarou por se assemelhar ou imitar o americano ou se tornaram, então, americanizados. Este artigo faz um alerta contra a tese forte da americanização através de um exame da introdução do estilo americano do plea bargaining em quatro sistemas da civil law Argentina, França, Alemanha e Itália. Demonstra-se que mesmo que cada um destes países tenha introduzido uma forma de plea bargaining, há pelo menos duas razões sérias que explicam por que estas jurisdições provavelmente não se americanizarão. Em primeiro lugar, há características importantes do sistema inquisitorial destes países da civil law que podem neutralizar o efeito de americanização da prática importada. Em segundo lugar, estas quatro jurisdições da civil law introduziram o plea bargain que apresenta diferenças - e até mesmo diferenças substanciais - não apenas do modelo americano, mas entre elas mesmo. Como consequência destas diferenças entre os modelos de plea bargain argentino, francês, alemão e italiano, o artigo demonstra que uma consequência paradoxal da influência americana sobre as jurisdições da civil law pode ser a produção de fragmentação e divergência, mais do que a americanização dos processos penais da tradição civil law. A fim de demonstrar estes pontos, o artigo redesenha duas estruturas conceituais. Em primeiro lugar, reconceitualiza-se os sistemas acusatório e inquisitório como categorias teóricas. $\mathrm{O}$ artigo demonstra que estes sistemas deveriam ser concebidos não apenas como duas formas distintas de distribuir poderes e responsabilidades entre os atores e instituições do sistema de justiça criminal. Em segundo lugar, o artigo também desafia a estrutura do transplante jurídico como uma maneira de se pensar a circulação de ideias e instituições jurídicas entre sistemas. Demonstra-se que a metáfora do transplante é muito rígida para explicar as transformações que as ideias e instituições jurídicas sofrem quando elas se deslocam para novos sistemas jurídicos.

Como alternativa, o artigo propõe a metáfora da tradução jurídica como um dispositivo heurístico alternativo para analisar a transferência de ideias e instituições jurídicas. Os sistemas acusatório e inquisitório, compreendidos como duas distintas culturas processuais, podem ser entendidos como dois sistemas diferentes de produção de significado. Então, a transferência de instituições jurídicas de um para outro sistema pode ser compreendida como traduções de um sistema de sentido para outro.

Palavras-chave

Processo penal. Plea bargaining. Transplantes jurídicos. Reformas jurídicas. Sistema acusatório. Sistema inquisitório. Americanização. Direito \& Cultura.

\section{Abstract}

This article analyzes the Americanization thesis in criminal procedure. According to the strong version of this thesis, the U.S. legal system has become the most influential system in the world and, as a 
consequence, a substantial number of legal systems may gradually come to resemble or mimic the American one and thus become Americanized. This article cautions against the strong version of the Americanization thesis through an examination of the introduction of American-style plea bargaining in four civil law countries - Argentina, France, Germany and Italy. It shows that even if each of these countries has introduced a form of plea bargaining, there are two main series of reasons that explain why these jurisdictions will probably not be Americanized. First, there are important features of civil law countries' inquisitorial system that may neutralize the Americanization effect of the imported practice. Second, these four civil law jurisdictions have introduced plea bargains that present differences - even substantial differences - not only from the American model but also among themselves. As a consequence of these differences between the Argentine, French, German and Italian plea bargains, the article shows that a paradoxical consequence of the American influence on civil law jurisdictions may be the production of fragmentation and divergence, rather than the Americanization of criminal procedures of the civil law tradition.

In order to demonstrate these points, this article redesigns two conceptual frameworks. First, it reconceptualizes the adversarial and inquisitorial systems as theoretical categories. The article shows that these systems should be conceived not only as two different techniques to handle criminal cases, but also as two different procedural cultures and as two different ways to distribute powers and responsibilities between the main actors and institutions of the criminal justice system. Second, the article also challenges the framework of the legal transplant as a way to think of the circulation of legal ideas and institutions between legal systems. It shows that the metaphor of the legal transplant is too rigid to account for the transformations that legal ideas and institutions undergo when they are moved into new legalsystems. Instead, the article proposes the metaphor of the legal translation as an alternative heuristic device when analyzing the transfer of legal ideas and institutions between legal systems. The adversarial and inquisitorial systems, understood as two different procedural cultures, can be understood as two different systems of productions of meaning. Thus, the transfer of legal institutions from one system to the other can be understood as translations from one system of meaning to the other.

\section{Keywords}

Criminal Procedure. Plea Bargaining, Legal Transplants. Judicial Reform. Adversarial system. Inquisitorial system. Americanization. Law \& Culture

\section{I- INTRODUÇÃO:}

Depois da Segunda Guerra Mundial, e particularmente após a Guerra fria, o sistema jurídico americano tornou-se o mais influente do mundo $^{3}$. Essa influência americana sobre os sistemas jurídicos de outras

3 Confira, e.g Duncan Kennedy, Three Legal Globalizations in The New Law and Economic Development. A Critical Appraisal, David Trubek and Alvaro Santos, eds., (Cambridge, 2006); Ugo Mattei, A Theory of Imperial Law: a Study on the U.S Hegemony and The Latin Resistance, 10 IND. J. GLOBAL LEGAL STUD. 383 (2003); Ugo Mattei, Why the Wind 
nações vai desde a forma de abordagem do direito pela teoria legal (por exemplo, pragmatismo legal, direito e economia ${ }^{4}$, o discurso dos direitos, etc.) ${ }^{5}$ até influências em áreas específicas (direito constitucional ${ }^{6}$, direito tributário $^{7}$, direito dos valores mobiliários $^{8}$, direito empresarial ${ }^{9}$, direito de patentes $^{10}$, arbitragem comercial internacional ${ }^{11}$, etc.); educação legal ${ }^{12}$ e da estruturação da profissão de advogado (grandes escritórios de advocacia ${ }^{13}$

Changed: Intellectual Leadership in Western Law, 42 AM J. COMP. L 195 (1994); Wolfgang Wiegand, Americanization of Law: Reception or Convergence?, in LEGAL CULTURE AND THE LEGAL PROFESSION 137 (Lawrence M. Friedman \& Harry Schreiber eds., 1996); Wolfgang Wiegand, The Reception of American Law in Europe, 39 AM. J. COMP. L 229 (1991).

${ }^{4}$ NT 1: O autor se refere aqui à corrente jurídica conhecida por "law and economics".

${ }^{5}$ Confira, v.g. Kennedy, op. cit, nota 3; Mattei, Why the Wind Changed, op. cit, nota 3.

${ }^{6}$ Confira CONSTITUTIONALISM AND RIGHTS: THE INFLUENCE OF THE UNITED STATES CONSTITUTION ABROAD (Louis Henkin \& Albert J. Rosenthal, 1990); Joan Devison, America's Impact on Constitutional Change in Eastern Europe, 55 ALB. L. REV. 793 (1992). Para um trabalho advertindo sobre a adoção do modelo constitucional norte-americano por outros países, Confira Jonathan Zasloff, The Tyranny of Madison, 44, UCLA, L. REV 795 (1997).

${ }^{7}$ Miranda Stewart, Global Trajectories of Tax Reform: The Discourse of Tax Reform in Developing and Transition Countries, 44, HARV. INT'L L. J. 139, 151 (2003).

8 Confira e.g Frederick Tung, Passports, Private Choice, and Private Interests: Regulatory Competition and Cooperation in Corporate Securities, and Bankruptcy Law, 3 CHI.J.INT'L L.369 n. 43 (2002).

9 Paul von Nessen, The Americanization of Australian Corporate Law, 26 SYRACUSE J. INT'L L. \& COM. 239 (1999).

${ }^{10}$ Confira e.g., Julia Alpert Gladstone, Why Patenting Information Technology and Business Methods is Not Sound Policy: Lessons From History and Prophecies for the Future, 25 HAMLINE L. REV. 217, 229 (2002).

11 YVES DEZALAY \& BRYANT G. GARTH, DEALING IN VIRTUE: INTERNATIONAL COMMERCIAL ARBITRATION AND THE CONSTRUCTION OF A TRANSNATIONAL LEGAL ORDER (1996).

${ }^{12}$ Confira e.g., Wiegand, Americanization, op cit. Nota 3, p. 138-139; Wiegand, The Reception, op. cit. nota 3, p. 232-233.

${ }^{13}$ Confira e.g., The Protectionist Bar Against Foreign Lanyers in Japan, China and Korea: Domestic Control in the Face of Internationalization, 16 COLUM. J. ASIAN L. 385, 389 (2003) ("A presença crescente de escritórios de advocacia no Japão encorajou uma posterior Americanização da prática jurídica, mas não sem restrições contínuas.”). 
e valorização de profissão jurídica privada ${ }^{14}$ ) até a reforma do judiciário ${ }^{15}$; das doutrinas ou ferramentas jurídicas específicas (regras de exclusão constitucionais $^{16}$, a doutrina da malícia expressa na liberdade de expressão e da imprensa ${ }^{17}$, ações de classe ${ }^{18}$, etc) aos arranjos institucionais como a separação dos poderes e a revisão das decisões judiciais ${ }^{19}$. Essas inegáveis influências americanas sobre outros sistemas jurídicos permitiu a certo número de doutrinadores, tanto nos Estados Unidos como fora dele, anunciar que um número considerável de sistemas jurídicos, ambos nos níveis nacional e internacional, podem se assemelhar ou imitar gradualmente o sistema jurídico americano e então, se tornarem "americanizados" "20. Outros doutrinadores, reconhecendo a influência predominante do sistema jurídico estadunidense não chegaram a asseverar

${ }^{14}$ Confira e.g., Bernard Michael Ortwein II, The Swedish Legal System: an introduction, 13, IND. INT'L. \& COMP. L. REV. 405 (2003) (n. 247: "Professor Mooder sustenta que a 'Americanização' das profissões jurídicas suecas resultou em um aumento no número de bacharéis em direito que procuram filiar-se à Associação Sueca de Advogados, esperando facilitar uma carreira no setor privado da prática jurídica”.).

${ }^{15}$ Confira e.g., Hiram E. Chodosh, Reforming Judicial Reform Inspired by U.S. Models, 52 DEPAUL L. REV. 351 (2002).

16 Argentina, Canadá, Itália e Espanha, entre outros países adotaram uma versão das regras de exclusão americanas, relativas a provas obtidas em violação a direitos constitucionais. Sobre a experiência canadense, Confira, por exemplo, James Stribopoulos, Lessons From the Pupil: a Canadian Solution to the American Exclusionary Rule Debate, 22 B.C.INT'L. \& COMP. L. REV. 77 (1999).

${ }^{17}$ Para uma análise da recepção desta doutrina pela Suprema Corte da Argentina, Confira, por exemplo, EDUARDO A. BERTONI, LIBERTAD DE EXPRESIÓN EN EL ESTADO DE DERECHO 72-82 (200).

18 Antonio Gidi, Class Actions in Brazil - A Model for Civil Law Countries, 51, AM. J. COMP. L. (2003) (apontando como as ações de classe anglo-americanas influenciaram os desenvolvimentos brasileiros através do trabalho de professores italianos).

${ }_{19}$ Confira e.g, Erhard Blankenburg, Changes in Political Regimes and Continuity of the Rule of Law in Germany, in HERBERT JACOB ET AL., COURTS LAW, AND POLITICS IN COMPARATIVE PERSPECTIVE 249, 308 (1996) (daqui para diante COURTS, LAW AND POLITICS).

${ }^{20}$ Confira e.g. R. Daniel Keleman \& Eric C. Sibbitt, The Americanization of Japanese Law, 23. U. PA. J. INT'L. ECON L. 269 (2002); Paul von Nessen, op. cit. nota 09; Wiegand, The Reception, op. cit., nota 03, p. 246-248 (comparando a "americanização" dos atuais sistemas jurídicos europeus à recepção do ius commune na Idade Média, naquele continente). 
que a influência estadunidense estaria recriando a sua prática jurídica em jurisdições não estadunidense ${ }^{21}$.

Neste artigo, eu faço uma advertência contra a anterior tese da americanização (a tese forte), através da análise da introdução do estilo plea bargaining estadunidense em quatro países de tradição civil law: Alemanha, Itália, Argentina e França ${ }^{22}$. A influência do plea bargaining estadunidense sobre todas estas quatro jurisdições é inegável. Apesar desta influência, contudo, a importação do plea bargaining nestas jurisdições não é suscetível de reproduzir um modelo estadunidense de processo criminal. Cada uma destas jurisdições adotou uma forma de plea bargaining que contem diferenças - às vezes substanciais - do modelo estadunidense, seja devido às decisões dos reformadores jurídicos em cada uma das jurisdições, seja devido às diferenças estruturais entre o processo penal estadunidense e os processos penais da tradição civil law. Consequentemente, algumas versões civil law do plea bargaining não se assemelharam à prática estadunidense desde o seu princípio. Ademais, as diferenças estruturais entre a concepção adversarial estadunidense de processo penal e a concepção inquisitorial da Europa continental e latino-americana de processo penal são tão profundas que reformas individuais inspiradas em modelos estadunidenses são incapazes de empurrar estes processos penais inquisitórios na direção do sistema adversarial estadunidense. Finalmente, em cada uma destas jurisdições baseadas no modelo civil law, alguns atores jurídicos

21 Confira e.g Gidi, op. cit nota 18; Kennedy op. cit nota 3; Stephen Zamora, The Americanization of Mexican Law: Non-Trade Issues in the North American Free Trade Agreement, 24 LAW \& POL'Y INT'L BUS. 391 (1993) (discutindo como a legislação trabalhista e ambiental e seus correlatos mecanismos de aplicação diferem daqueles dos Estados Unidos, apesar das pressões sobre o sistema jurídico mexicano para imitar o estadunidense).

22 Eu escolhi estas quatro jurisdições por duas razões. Primeiro, elas têm sido tradicionalmente consideradas influentes em outros países (França, Alemanha e Itália no mundo inteiro e Argentina na América Latina). Deste modo, à medida que elas ainda retêm parte de sua ascendência sobre outras jurisdições civil law, elas podem fornecer uma boa representação sobre o que pode acontecer em boa parte da civil law. Segundo, cada uma destas jurisdições oferece uma diferente versão sobre como o plea bargaining pode ser importado pelos países pertencentes à tradição civil law e que diferentes efeitos estas diversas versões podem produzir em cada um deles. 
desacreditaram ou resistiram à adoção do plea bargaining e outros mecanismos consensuais, seja porque estas reformas ameaçaram seus poderes tradicionais no sistema inquisitorial em vigor, seja devido às diferenças na cultura jurídica. Esta desconfiança e resistência jogaram um papel decisivo na neutralização do potencial para a americanização inerente a algumas destas reformas no processo penal.

Embora os fatores dificultadores da americanização estejam presentes em cada uma das jurisdições civil law examinadas, eles desempenharam papeis diferentes em cada uma dessas jurisdições. Cada um dos países estudados adotou não somente um sistema de plea bargaining diferente do estadunidense, mas também, cada uma destas jurisdições adotou formas de plea bargaining diferentes entre si. Os plea bargains alemão, francês, italiano e argentino se diferenciam substancialmente entre si devido às decisões dos reformadores jurídicos em cada um destes países, às diferentes formas nas quais a prática foi introduzida e à resistência que foi gerada. Dadas as diferenças entre estes plea-bargains, a adoção de algumas formas de plea bargaining nestas jurisdições pode produzir diferentes transformações ou efeitos em cada uma dessas jurisdições. Portanto, a potencial influência do plea bargaining estadunidense sobre as jurisdições civil law pode não significar que os sistemas civil law se assemelharão gradativamente ao sistema jurídico estadunidense, mas ao invés, que eles podem começar a se diferenciar entre si em aspectos nos quais, até recentemente, eles eram relativamente homogêneos. Em outras palavras, o efeito paradoxal da influência estadunidense nos processos penais de tradição civil law pode não significar americanização mas antes fragmentação e divergências entre sistemas civil law.

Antes de começar a análise concreta destas importações é preciso esclarecer dois pontos. Primeiro, a fim de explicar e rastrear as transformações que o plea bargaining estadunidense experimentou antes de ser adotado por estas jurisdições civil law, é preciso explicar a diferença histórica entre o processo penal adversarial estadunidense e os processos penais inquisitoriais da tradição civil law. Os sistemas adversarial e inquisitorial podem ser compreendidos não apenas como duas formas de distribuição de poderes e responsabilidades entre os diversos atores jurídicos - o julgador (juiz e/ou júri), o acusador e a defesa - mas também 
como duas diferentes culturas processuais e deste modo, dois conjuntos diversos de compreensões básicas de como os casos penais deveriam ser processados e julgados ${ }^{23}$. A grande diferença entre as culturas processuais, para os propósitos deste artigo, é a de que enquanto o sistema adversarial concebe o processo penal como uma disputa entre duas partes (acusação e defesa) perante um julgador passivo (juiz e/ou júri), o sistema inquisitorial concebe o processo penal como uma investigação oficial, realizada por um ou mais agentes oficiais do Estado, a fim de determinar a verdade ${ }^{24}$.

Dado que estas diferenças culturais foram negligenciadas pelas análises acadêmicas tradicionais, eu proponho neste artigo um novo quadro teórico para reconceitualizar os sistemas adversarial e inquisitorial. Este novo quadro teórico será útil não apenas para descrever as diferenças entre os processos penais das tradições common e civil law como também para analisar algumas das transformações que o plea barganining - e potencialmente outros institutos jurídicos - podem sofrer quando transferidos de um sistema para outro. Este quadro teórico também será útil para avaliar a americanização, trazida pela adoção de alguma forma de plea bargaining nestes quatro processos penais civil law, porque ele fornecerá um claro eixo referencial para comparação de diferenças entre os sistemas

\footnotetext{
${ }^{23}$ Neste sentido, é importante enfatizar desde o início que eu usarei a expressão "sistema adversarial" como uma categoria descritiva, não como um ideal normativo. Como um ideal normativo, a expressão é algumas vezes usada nos Estados Unidos para se referir ao processo penal no qual os direitos do acusado são completamente respeitados, Confira, e.g. Mirjan Damaška, Adversary System, 1 ENCICLOPEDIA OF CRIME AND JUSTICE, 24, 25 (Sanford H. Khadish ed., 1983) e o epítome de que o sistema adversarial é o julgamento pelo júri. Contudo, neste artigo, eu usarei a expressão "sistema adversarial" como uma categoria descritiva pela qual explicarei as características atuais do processo penal americano em oposição às características atuais do processo penal na Europa Continental e América Latina. Igualmente, a expressão "sistema inquisitorial" é usada algumas vezes de uma forma negativa, para se referir a concepções autoritárias de processo penal. Mas neste artigo eu usarei a expressão "sistema inquisitorial" apenas como uma categoria descritiva.

${ }^{24}$ Como eu explicarei mais adiante eu não concebo os sistemas adversarial e inquisitorial como culturas processuais homogêneas. Mas estas duas concepções têm sido predominantes nas cinco jurisdições que eu examinarei neste artigo e deste modo são as mais relevantes para este estudo.
} 
adversarial e inquisitorial, e desta forma, na avaliação se este último está caminhando na direção do primeiro.

Segundo, é necessário questionar e reavaliar como nós pensamos a circulação de ideias jurídicas entre sistemas jurídicos. A metáfora do "transplante legal" (legal transplant) tem sido o principal dispositivo usado por pesquisadores e praticantes do direito comparado para analisar a importação de práticas jurídicas estrangeiras ${ }^{25}$. A metáfora, contudo, possui deficiências. O seu principal problema é que transmite a noção de que ideias e instituições podem ser simplesmente "recortadas e coladas" entre os sistemas jurídicos. Dessa maneira, a metáfora falha na explicação da transformação que ideias e instituições jurídicas podem sofrer quando transferidas entre sistemas jurídicos. Neste artigo, eu proponho o uso da metáfora da "tradução legal" (legal translation) como um dispositivo heurístico alternativo para ser empregado na análise da transferência de ideias e institutos entre sistemas jurídicos. Os sistemas adversarial e inquisitorial, compreendidos como duas diferentes culturas processuais, podem ser entendidos como dois diversos sistemas de produção de significado. Desse modo, a transferência de instituições jurídicas de um sistema para outro pode ser compreendida como traduções de um sistema

25 Confira genericamente DANIEL BERKOWITZ ET AL., ECONOMIC DEVELOPMENT, LEGALITY AND THE TRANSPLANT EFFECT (Center for International Development at Harvard University, Working Paper No 39, 2000, disponível em http://www.cid.harvard.edu/cidwp/039.htm (última visita em 25 de Novembro de 2003); EDGARDO BUSCAGLIA \& WILLIAM RAFLIFF, LAW AND ECONOMICS IN DEVELOPING COUNTRIES 14-19, 31-54 (2000); ALAN WATSON, LEGAL TRANSPLANTS: AN APPROACH TO COMPARATIVE LAW 21 (2 ed 1993); Gianmaria Ajani, By Chance and Prestige: Legal Transplants in Russia and Easter Europe, 43 AM J.COMP L. 93 (1995); Ugo Mattei, Efficiency in Legal Transplants: An Essay in Comparative Law and Economics, 14 INT'L REV. L \& ECON. 3 (1994); Jonathan M. Miller, A Typology of Legal Transplants: Using Sociology, History and Argentinian Example to Explain the Transplants Process, 51 AM. J. COMP. L. (2003); Loukas A. Mistelis, Regulatory Aspects: Globalization, Harmonization, Legal Transplants and Law Reform - Some Fundamental Observations, 34 INT'L LAW 1055 (2000); Frederick Schauer, The Politics and Incentives of Legal Transplantation, in GOVERNANCE IN A GLOBALIZING WORLD, 253 (Joseph S. Nye Jr \& John Donahue eds., 2000); Jonathan B. Weiner, Responding to the Global Warming Problem: Something Borrowed for Sometbing Blue: Legal Transplants and the Evolution of Global Environmental Law, 27, ECOLOGY L.Q. 1295 (2001). 
de significado para outro. Especificamente, as transformações que o plea bargaining sofreu ao ser transferido para estes sistemas civil law podem ser vistas tanto como decisões tomadas por os "tradutores" (i.e reformadores jurídicos) como um produto das diferenças estruturais entre as "linguagens" acusatória ou inquisitorial.

Neste artigo, eu mostro que a influência do processo penal americano parece confirmar a versão fraca da tese da americanização e que a versão forte é inaplicável, ou, ao menos, demasiadamente simplista, relativamente ao processo penal. Apesar da influência do plea bargaining americano nas jurisdições civil law, as diferenças culturais entre os sistemas adversarial e inquisitorial são muito profundas para serem sobrepujadas por uma simples reforma inspirada no modelo americano, ou até mesmo um número substancial de reformas. Além disso, considerando que cada uma dessas jurisdições civil law traduziu o plea bargaining de uma forma diferente, o efeito derradeiro desta influência estadunidense pode acabar sendo a fragmentação e a divergência, ao invés da americanização do processo penal civil law. As quatro jurisdições examinadas neste artigo compartilham uma cultura processual predominante que considera o processo penal como uma investigação oficial conduzida por agentes estatais imparciais. Contudo, cada jurisdição adotou uma versão diferente do plea bargaining e, com isso, estas diferentes reformas podem conduzi-las em diferentes direções.

A estrutura deste artigo é a seguinte. Nas partes II e III eu proponho um novo quadro teórico para conceitualizar os sistemas adversarial e inquisitorial. A ideia principal que eu defendo aqui é a de que estas duas categorias deveriam ser compreendidas não apenas como duas formas diferentes de organizar poderes e responsabilidades entre os principais atores do processo penal (juízes, acusadores, advogados de defesa e etc.), mas também como duas diferentes culturas processuais. A parte IV mostra as influências que a concepção anglo-americana de processo penal teve sobre o processo penal inquisitorial da Europa Continental e América Latina nas últimas décadas. A parte $\mathrm{V}$ discute os problemas apresentados pela metáfora do "transplante legal" como um dispositivo heurístico de análise da circulação de instituições jurídicas entre sistemas. Em seu lugar eu ofereço a metáfora da "tradução legal" (legal 
translation) como um dispositivo heurístico de maior nuance e produtividade para pensar estes assuntos. A prática jurídica transferida - o plea bargaining neste caso - pode ser pensado como um "texto" que foi traduzido de uma "linguagem" - o sistema adversarial estadunidense - para outra "linguagem"- os sistemas inquisitoriais da Alemanha, Itália, Argentina e França. A parte VI explica como o plea bargaining poderia ter um efeito potencial de americanização nas jurisdições civil law caso fosse totalmente aceito por estes sistemas. Meu argumento aqui é o de que o plea bargaining americano pressupõe uma concepção adversarial de processo penal, e, portanto, caso fielmente traduzido e completamente aceito pelas jurisdições civil law, poderia fazer avançar uma concepção estadunidense de processo penal nas jurisdições inquisitoriais.

As partes VII, VIII, IX e X analisam os plea bargains alemão, italiano, argentino e francês e explica não por que cada um destes países traduziu o plea bargaining estadunidense, mas também por que cada um deles escolheu traduzir a prática de uma maneira diversa. Aqui, eu também demonstro como a concepção cultural inquisitória de processo penal tem sido uma das razões principais pelas quais os plea bargains estadunidenses foram transformados e resistidos nestas jurisdições. Finalmente, a parte XI traça o meu argumento central: dado que cada uma das jurisdições examinadas traduziu o plea barganing de uma maneira diversa, as influências estadunidenses podem acabar produzindo fragmentação e divergência, ao invés da americanização do processo penal na tradição civil law.

\section{II- RECONCEITUALIZANDO O SISTEMA ADVERSARIAL E O SISTEMA INQUISITORIAL COMO CATEGORIAS TEÓRICAS.}

Tradicionalmente, estudiosos do direito comparado e do processo penal comparado empregaram as categorias teóricas "adversarial" e "inquisitorial" através de duas perspectivas primárias ${ }^{26}$ : a do mínimo

${ }^{26} \mathrm{O}$ uso das expressões "adversarial" e "inquisitorial” não ficou limitado ao processo penal comparado. Para descrições de outros usos destes termos Confira Mirjan Damaška, Adversary System, in 1 ENCYCLOPEDIA OF CRIME AND JUSTICE, 24 (Sanford 
denominador comum (lowest-common-denominator) e a do tipo ideal (ideal-type approach $)^{27}$.

De acordo com a perspectiva do mínimo denominador comum, as categorias adversarial e inquisitorial simplesmente possuem características comuns a todos os processos penais do sistema common e civil law, respectivamente ${ }^{28}$. Por exemplo, o julgamento pelo júri ou a proibição da prova de ouvir-dizer (hearsay rule) seriam características do sistema adversarial se todas as jurisdições common law incluíssem estes elementos em um determinado momento. Esta abordagem possui diversos problemas. Primeiro, cada vez que uma jurisdição em particular deixar de lado uma característica que foi parte deste mínimo denominador comum, os pesquisadores se colocam diante do seguinte dilema: ou eles têm de modificar o conteúdo das categorias adversarial e inquisitorial ou eles têm de remover esta jurisdição do sistema adversarial ou do sistema inquisitorial. A perspectiva do mínimo denominador comum não oferece

Khadish ed., 1983); Malcolm Feeley, The Adversary System, in ENCYCLOPEDIA OF THE AMERICAN JUDICIAL SYSTEM 753 (Robert J. Janosik ed., 1987); Máximo Langer, La dicotomía acusatorio-inquisitivo y la importación de mecanismos procesales de la tradición juridical anglo-sajona. Algunas reflexiones a partir del procedimiento abreviado, in EL PROCEDIMIENTO ABREVIADO, 97, 102-11 (Julio B Maier \& Alberto Bovino eds., 2001). Para estudos de outros modelos e categorias que foram usados para analisar diferentes espécies de processo penal Confira HERBERT L. PACKER, THE LIMITS OF THE CRIMINAL SANCTION, 149-246 (1968); Peter Arenella, Retbinking The Functions of Criminal Procedure: The Warren and Burger Courts' Competing Ideologies, 72 GEO L.J 183 (1983); Mirjan Damaška, Models of Criminal Procedure, 51 ZBORNIK (COLLECTED PAPERS OF ZAGREB LAW SCHOOL) 477 (2001); John Griffiths, Ideology in Criminal Procedure, or a Third "Model" of The Criminal Process, 79, YALE L.J 359 (1970); Erik J. Luna, The Models of Criminal Procedure, 2 BUFF, CRIM. L. REV. 389 (1999).

${ }^{27}$ Confira genericamente MIRJAN R. DAMAŠKA, THE FACES OF JUSTICE AND STATE AUTHORITY 4-6 (1986).

${ }^{28}$ Confira Mirjan Damaška, Adversary System, op. cit. nota 23, na 28 (oferecendo, como um exemplo desta perspectiva; Joachim Herrmann, Various Models of Criminal Proceedings $2 \mathrm{~S}$. AFR. J. CRIM. L \& CRIMINOLOGY, 3, 4-6 (1978)). A fim de rejeitar a ideia de que a inadmissibilidade, no processo, das provas obtidas ilicitamente não é uma característica definidora da perspectiva adversarial, Prof. Herrmann menciona que as regras de exclusão não foram adotadas por todas as jurisdições anglo-americanas, e que ela foi adotada nas legislações de diversos países europeus. Id. na 18). 
uma resposta clara para lidar com este dilema ${ }^{29}$. Segundo, não fica clara a distinção entre as características primárias e secundárias de ambos os sistemas. Em outras palavras, a perspectiva do mínimo denominador comum não oferece uma resposta para a questão de por que determinadas características são mais relevantes do que outras para a distinção entre os sistemas $^{30}$. Terceiro, esta perspectiva não se mostra útil para analisar sistemas híbridos, que foram influenciados por ambas as tradições jurídicas e talvez também por outras tradições do mundo. Estes sistemas mistos são importantes fenômenos a serem estudados agora, não apenas por que a incidência de sistemas nacionais híbridos é maior do que no passado devido a mútuas influências entre common e civil law, mas também a fim de compreender os tribunais penais internacionais, de Nuremberg ao Tribunal Penal Internacional, onde regras e profissionais de diferentes tradições jurídicas se encontram e interagem ${ }^{31}$. Por fim, esta perspectiva não parece fornecer um quadro teórico útil para lidar com o fenômeno das influências e transplantes jurídicos, porque o máximo que esta abordagem pode oferecer quando uma prática jurídica (como o plea bargaining) é transferida de uma jurisdição adversarial para uma inquisitorial é: ou a ausência desta instituição não é mais uma característica definidora do sistema inquisitorial ou que a específica jurisdição recebedora não é mais parte da família jurídica inquisitorial, nos levando assim de volta ao primeiro problema da abordagem do mínimo denominador comum.

\footnotetext{
${ }^{29}$ Confira DAMAŠKA, op. cit. nota 27 , na 5 .

${ }^{30}$ Confira Id.
}

${ }^{31}$ Para análises de procedimento e de regras probatórias de diferentes jurisdições penais internacionais baseadas na dicotomia adversarial e inquisitorial Confira, por exemplo, Guillaume Champy, Inquisitoire-Accusatoire devant les jurisdictions pénales internationales, 68, INT'L. REV. PENAL L. 149 (1997); Nancy Amoury Combs, Copping a Plea for Genocide: The Plea Bargaining of International Crimes, 151, U. PA. L. REV. 1 (2002); Richard May \& Marieke Wierda, Trends in International Criminal Evidence: Nuremberg, Tokyo, The Hague, and Arusha, 37 COLUM. J. TRANSNAT'L L.725 (1999); Daryl A. Mundis, From 'Common Law' Towards 'Civil Law': The Evolution of the ICTY Rules of Procedure and Evidence, 14 LEIDEN J. INT'L. L. 367 (2001); Vladimir Tochilovsky, Rules of Procedure for the International Criminal Court: Problems to Address in the Light of Experience of the Ad Hoc Tribunals, 46, NETH. INT'L L. REV. 343 (1999). 
A segunda principal perspectiva para o processo penal comparado tem sido conceitualizar o adversarial e o inquisitorial como tipos-ideais weberianos. ${ }^{32}$. Estes modelos não existem exatamente em quaisquer sistemas jurídicos históricos, porém, assim como as jurisdições common law se aproximariam do tipo adversarial, as jurisdições civil law se aproximariam do tipo inquisitório ${ }^{33}$.

Esta perspectiva teórica é muito mais promissora do que a aquela do mínimo denominador comum e corrige muitas de suas falhas. Por exemplo, o uso de tipos-ideais identifica diferenças relevantes entre os sistemas adversarial e inquisitorial e uma mudança concreta no processo penal de um sistema não leva necessariamente à mudança ou ao abandono do modelo. Ao invés disso, esta abordagem apenas rotula o sistema como mais próximo ou mais afastado do tipo-ideal. Além disso, a abordagem do tipo-ideal também pode ser profícua ao se analisar processos penais híbridos, como os tribunais penais internacionais, identificando as características que correspondem a cada tipo ${ }^{34}$. A abordagem do tipo-ideal também fornece um quadro teórico útil para analisar o fenômeno das influências e do transplante jurídico entre sistemas common e civil law ${ }^{35}$. Primeiramente, oferecendo um claro eixo de referência, esta abordagem

32 Em sua clássica descrição da metodologia de Weber, Max Rheinstein escreve: "situações de tal tipo "puro" nunca existiram na história. Nenhum triângulo, cubo ou esfera pura jamais existiu. Mas jamais a realidade poderia ter sido penetrada sem o uso de conceitos artificiais da geometria. Para os conceitos "puros" criados por ele, Weber usou o termo "tipo ideal"....Os tipos ideais....são nada mais do que construções mentais com a intenção de servir como categorias do pensamento, de cujo uso nos ajudará a capturar a infinita multiplicidade da realidade pela comparação de seus fenômenos com aqueles "tipos puros" que são usados, por assim dizer, para servir como guia em um sistema de arquivamento. Max Rheinstein, Introduction to MAX WEBER ON LAW IN ECONOMY AND SOCIETY XXIX - XXX (Edward Schils \& Mas Rheinstein trans. Max Rheinstein ed., 1954).

33 Mirjan Damaška mostrou o uso mais sofisticado desta perspectiva, embora tenha substituído o adversarial e o inquisitorial pelas suas próprias categorias. Confira DAMAŠKA, op. cit. nota 27.

${ }^{34}$ Confira e.g. Tochilovsky, op. cit. nota 31.

35 Confira Mirjan Damaška, The Uncertain Fate of Evidentiary transplants: Anglo-American and Continental Experiences, 45 AM. J. COMP. L. 389 (1997); Elisabetta Grande, Italian Criminal Justice: Borrowing and Resistance, 48 AM. J. COMP.L. 227 (2000). 
nos permite analisar a extensão das transformações do processo penal como consequência das influências ou do transplante. Em segundo lugar, na medida em que os processos penais concretos são mais próximos dos tipos ideais, eles explicam os estímulos e a lógica do sistema, tornando assim possível identificar, antecipadamente, potenciais focos de resistência à reforma.

\section{A. ESTRUTURAS DE INTERPRETAÇÃO E SIGNIFICADOS.}

Todavia, existe um ponto que a abordagem do tipo ideal não trata, ou deixa em segundo plano e que eu gostaria de trazer para o primeiro plano. Os modelos adversarial e inquisitorial não são apenas dois modos de estruturar os procedimentos criminais, mas também duas formas de entender e representar o processo penal. Por exemplo, os juízes da common law participam nas oitivas das testemunhas muito menos do que os seus colegas do Continente, não apenas por que regras processuais lhes oferecem menores poderes para fazê-lo, mas também por que o papel do juiz é compreendido diferentemente no sistema common law. Enquanto o juiz do sistema inquisitorial é entendido e percebido como um investigador ativo com, consequentemente, o dever de ser ativo nestas tomadas de depoimentos, o juiz do sistema adversarial é geralmente compreendido como um árbitro passivo que se presume não deva participar ativamente na tomada de depoimentos das testemunhas ${ }^{36}$.

${ }^{36}$ Com a reconceitualização dos sistemas adversarial e inquisitorial desenvolvida neste artigo, eu estou tentando capturar o ponto de vista interno dos atores jurídicos que são parte dos processos criminais da common e da civil law. Esta distinção entre ponto de vista interno e externo tem sido usada em uma multiplicidade de disciplinas. Por exemplo, Max Weber levou esta distinção em consideração para incluir como objeto de estudo sociológico não apenas os aspectos externos do comportamento humano mas também o sentido que seres humanos atribuem a seus próprios comportamentos. Confira Rheinstein, op.cit, nota 32, na XXIX-XXX: "a observação de que um homem entrega para outro um pedaço de papel esverdeado é irrelevante no estudo das relações humanas. O fenômeno observado não assume significância social até nós sabermos que um grande grupo de seres humanos, do qual nossos dois atores são membros, considera o papel verde como um pedaço de papel moeda ou, em outras palavras, que eles atribuem a ele a função de servir como um genericamente reconhecido meio de troca e pagamento. Id. na 
Em outras palavras, adversarial e inquisitorial podem ser entendidos como diferentes estruturas de interpretação e significado através das quais os atores de um determinado sistema de justiça criminal compreendem tanto o processo penal quanto o seu papel dentro dele ${ }^{37}$. Dentro destas duas estruturas processuais de interpretação e significado ou "linguagem processual", os mesmos termos ou significantes podem ter significados diferentes. Por exemplo, no sistema adversarial a palavra "promotor" significa uma parte em uma disputa com interesses em jogo no resultado do processo; no sistema inquisitorial, entretanto, esta palavra significa um magistrado imparcial do Estado cujo papel é investigar a verdade $^{38}$.

XX. Na filosofia do direito, a clássica referência é H.L.A Hart, que usou esta distinção entre pontos de vista internos e externos. H.L.A HART THE CONCEPT OF LAW 8891 (2 ed 1994). Confira também PAUL W. KAHN, THE CULTURAL STUDY OF THE LAW (1999). Nos estudos antropológicos Clifford Geertz tentou capturar a ideia de ponto de vista interno através de seu conceito de "descrição densa". CLIFFORD GEERTZ, THE INTERPRETATION OF CULTURES 5-10 (1973). Desde que Weber coerentemente usou a perspectiva do tipo ideal e levou em consideração o ponto de vista interno dos atores sociais, eu não considero minha reconceitualização dos sistemas adversarial e inquisitorial como incompatível com a perspectiva do tipo ideal; eu penso que elas são simplesmente independentes uma da outra. Meu argumento é o de que a análise de processo penal comparado geralmente desprezou o ponto de vista interno dos atores do sistema de justiça criminal e que incluir esta perspectiva é central para examinar as diferenças entre os processos penais da common e civil law e os fenômenos como a circulação de ideias jurídicas e instituições assim como para debates sobre a americanização do direito.

${ }^{37}$ Eu tomo a expressão "estruturas de significado" de Clifford Geertz, Local Knowledge: Fact and Law in Comparative Perspective, in LOCAL KNOWLEDGE: FURTHER ESSAYS IN INTERPRETATIVE ANTHROPOLOGY, 167, 182 (1983) (que declara: "a virada da antropologia ... em direção a uma mais elevada preocupação com estruturas de significado em termos nos quais indivíduos e grupos de indivíduos vivem suas vidas e mais particularmente, com os símbolos e sistemas de símbolos através de cuja operação tais estruturas são formadas, comunicadas, impostas, compartilhadas, alteradas, reproduzidas, promete tanto para a análise comparada do direito quanto para o mito, ritual, ideologia, arte, ou sistemas de classificação, os mais testados campos para sua aplicação". Id).

38 Sobre as diferentes concepções de promotor no sistema anglo-americano e no inquisitorial Confira, por exemplo, William T. Pizzi, Understanding Prosecutorial Discretion in The United States: The Limits of Comparative Criminal Procedure as an Instrument of Reform, 54 
A palavra "verdade" também possui um significado diferente em cada estrutura processual de interpretação e significado. No sistema adversarial, mesmo que a disputa seja sobre a "verdade", a acusação tenta provar que certos eventos ocorreram e que o réu participou deles, enquanto que a defesa tenta questionar ou frustrar esta tentativa. $O$ conceito adversarial de verdade é mais consensual e relativo: se as partes chegam a um acordo sobre os fatos do caso, através de plea agreements ou stipulations, é menos importante determinar como os eventos se sucederam $^{39}$. Na estrutura inquisitorial de interpretação e significado, a "verdade" é concebida em termos mais absolutos: o oficial do Estado tradicionalmente o juiz - é encarregado de determinar, através de uma investigação, o que realmente aconteceu, independentemente de acordos ou desacordos que a acusação e a defesa possam ter acerca do evento ${ }^{40}$.

Ao mesmo tempo, existem certas ideias e conceitos que existem em uma linguagem processual e não na outra. Por exemplo, o sistema adversarial contem simultaneamente o conceito de "confissão"- i.e, uma admissão de culpa perante a polícia - e o "guilty plea" - uma admissão de culpa perante a Corte que, se aceita, tem como consequência encerrar a fase de instrução processual e a fase de julgamento (phase of determination of guilt or innocence). A estrutura processual inquisitorial de interpretação e significado ou "linguagem", por outro lado, não inclui o conceito de "guilty plea"; ela apenas inclui o conceito de "confissão"

OHIO ST. LJ. 1325, 1349-51 (1993); Thomas Weigend, Prosecution: Comparative Aspects in 3 ENCYCLOPEDIA OF CRIME \& JUSTICE, 1232, 1233-34 (Joshua Dressler ed. 2 ed., 2002).

${ }^{39}$ Isto pode soar como um exagero porque, nas jurisdições americanas, o juiz ainda tem de verificar a base factual para um guilty plea. Mas na prática, os juízes americanos são geralmente deferentes aos acordos das partes sobre os fatos. Além disso, casos como Carolina do Norte v. Alford, 400 U. S (1970), no qual o acusado declarado culpado enquanto reivindicava que na realidade era inocente são exemplos claros de uma concepção de verdade que é muito mais relativa e consensual.

40 Sobre a concepção de verdade predominante no sistema inquisitorial como oposta à acusatória, Confira Antoine Garapon, French Legal Culture and the Shock of Globalization, 4 SOC \& LEGAL STUD. 493, 496-97 (1995).

${ }^{41}$ Cf e.g Myron Moskovitz, PERSPECTIVE: The O. J. Inquisition: A United States Encounter with Continental Criminal Justice, 28, VAND. J. TRANSNAT'L L. 1121, 1153 (1995). Este artigo descreve as diferenças entre os sistemas adversarial e inquisitorial 
Neste sistema, o réu não pode encerrar a fase de instrução processual e a fase de julgamento admitindo a sua culpa perante o tribunal. Enquanto a admissão da culpa pode ser muito útil para o juiz na busca da verdade, o juiz ainda tem a palavra final na determinação da culpa e pode, então dizer "eu acredito em você, mas a sua confissão, isolada, não é uma prova que supera a dúvida razoável sobre a sua autoria”. De qualquer forma, se uma admissão da autoria ocorrer na fase de investigação preliminar, o caso ainda deverá ir a julgamento para que o juiz tome uma decisão final ${ }^{42}$.

É importante enfatizar que mesmo que fosse possível analisar as estruturas de interpretação e significados adversarial e inquisitorial como sistemas abstratos, estas estruturas apenas existiriam em sistemas processuais penais concretos. Em outras palavras, é possível identificar sistemas adversariais e inquisitoriais por que os atores legais das jurisdições anglo-americanas e civil law constantemente usam as estruturas de interpretação e significados adversarial e inquisitorial de forma consciente e inconsciente. Tomando uma distinção da linguística estruturalista, eu poderia dizer que enquanto as estruturas de interpretação e significados são a langue - o sistema abstrato de diferenças que estabelecem um léxico e um conjunto de potenciais operações - as práticas são a parole - os atos de fala atuais tornados possíveis pela langue $e^{43}$.

\section{B. DISPOSIÇÕES INDIVIDUAIS.}

Assim como as estruturas de interpretação e significado adversarial e inquisitorial estão fundamentadas em práticas processuais concretas, elas também são internalizadas por relevantes atores jurídicos. Eu chamo isso de "dimensão da disposição individual" ". Estas disposições internas são

através do desenvolvimento de uma dramatização de como um caso similar ao julgamento de O. J. Simpson seria tratado por um sistema de justiça criminal europeu, de tradição civil law.

42 Confira e.g JOHN H. LANGBEIN, COMPARATIVE CRIMINAL PROCEDURE: GERMANY, 73-74 (1977).

${ }^{43}$ Confira FERDINAND DE SAUSSURE, COURSE IN GENERAL LINGUISTICS (Wade Baskin Trans. Charles Bally \&Albert Reidinger eds, 1959).

${ }_{44}$ Minha fonte de inspiração para o desenvolvimento desta dimensão de predisposições internas é o conceito sociológico de habitus, de Pierre Bourdieu, que pode ser definido 
adquiridas pela internalização de estruturas processuais de interpretação e significado, mediante um número de processos de socialização (i.e escolas de direito, escolas da magistratura, escritórios da promotoria, treinamento de escritórios de advocacia, interação com os tribunais, etc) ${ }^{45}$. Como resultado desta socialização, um número considerável de atores do sistema de justiça criminal está predisposto a compreender o processo penal e os seus vários papeis de uma forma particular e estas disposições se tornam estáveis no tempo.

Por isso, a ideia de que o juiz deve ser um árbitro imparcial no sistema adversarial é devida não apenas à estrutura adversarial de interpretação de significado; é devida também ao fenômeno de que um número considerável de atores jurídicos internalizaram esta estrutura de significado em uma jurisdição common law e eles devem considerar isto como um papel adequado a um juiz que agirá geralmente de acordo - i.e censurando um juiz que participa muito ativamente da tomada de depoimento das testemunhas ${ }^{46}$. Em outras palavras, à medida que os atores jurídicos internalizam estas estruturas de significado, e então interpretam e interagem com a realidade através delas, seria possível dizer

como "um conjunto de disposições as quais induzem os agentes a agir ou reagir de determinadas formas. As disposições geram práticas, percepções e atitudes que são 'regulares' sem ser conscientemente coordenadas ou governadas por alguma regra". John B. Thompson, Editor's Introduction to PIERRE BOURDIEU, LANGUAGE AND SYMBOLIC POWER 1, 12 (Gino Raymond \& Matthew Adamson trans., John B. Thompson ed. 1991). Pierre Bourdieu descreve sua noção de habitus em outros trabalhos igualmente. PIERRE BOURDIEU, RAISON PRATIQUES: SUR LA THÉORIE DE L'ACTION 22 - 23 (1994); PIERRE BOURDIEU, Some Properties of Fields, in SOCIOLOGY IN QUESTION 72 (Richard Nice trans., 1993). Eu digo que a dimensão das disposições internas é apenas inspirada pelo conceito de Bourdieu, uma vez que eu não sigo o seu enquadramento teórico neste artigo. Desse modo, meu uso dele é idiossincrático.

45 Para uma descrição de como advogados, juízes, promotores e professores são treinados e socializados nos países de tradição civil law Confira, por exemplo, JOHN HENRY MERRYMAN, THE CIVIL LAW TRADITION 101-10 (2 ed.1985).

${ }^{46}$ Sobre o papel do juiz durante o julgamento, nos Estados Unidos Confira, por exemplo, Craig M. Bradley, United States, in CRIMINAL PROCEDURE: A WORLDWIDE STUDY 395, 421-422 (Caig M. Bradley ed.,1999). 
que estas estruturas de significado constituem e moldam os atores jurídicos como sujeitos ${ }^{47}$.

A dimensão das disposições individuais se torna particularmente importante quando estudamos a transferência de ideias, normas, e institutos jurídicos entre os sistemas adversarial e inquisitorial bem como os transplantes jurídicos em geral. Como veremos, parte da literatura dos transplantes jurídicos discute a transferência de ideias jurídicas da common para a civil law e vice-versa, exclusivamente como interações e batalhas entre dois sistemas abstratos de significado ${ }^{48}$. Através da inclusão desta dimensão de disposições individuais, eu gostaria de enfatizar que além dessas interações entre dois sistemas abstratos - uma vez mais, como eu os concebo, eles estão inscritos em práticas sociais - cada transplante jurídico também envolve interações entre pessoas concretas com um conjunto concreto de disposições individuais.

Além do mais, esta dimensão também é importante para entendermos como sistemas processuais - quaisquer outras estruturas de interpretação e significado - podem mudar com o passar do tempo. A relação entre estruturas processuais de significado e disposições individuais é influenciada por estruturas de significado à medida que os atores individuais adquirem, através de inúmeros processos de socialização, um concreto sistema de interpretação que, em certa medida, os configura para agir e reagir de determinadas maneiras. Porém, se um número considerável de atores internalizarem uma estrutura diferente de significado (i.e, quando advogados do sistema civil law estudam nos Estados Unidos e adquirem parcialmente uma estrutura de significado adversarial), isto pode levá-los a questionar a estrutura predominante de significado (i.e, o sistema

\footnotetext{
47 Para uma recente análise - no contexto do debate nos Estados Unidos sobre o policiamento baseado na teoria das janelas quebradas (broken windows) - ou sobre como as práticas do direito penal e do sistema de justiça criminal moldam sujeitos Confira BERNARD E. HARCOURT, ILLUSION OF ORDER 160 (2001).

${ }^{48}$ Confira e.g Gunter Teubner, Legal Irritants: Good Faith in British Law or How Unifying Law Ends Up in New Divergences, 61 MOD. L. REV. 11(1998).
} 
inquisitorial) e tentar incorporar práticas de outros sistemas - como o plea barganing - em seus próprios sistemas jurídicos ${ }^{49}$.

\section{PODERES PROCESSUAIS.}

Finalmente, os sistemas adversarial e inquisitorial se diferem entre si em outro nível que eu chamo de "dimensão dos poderes processuais" Os principais atores no processo penal - juízes, promotores, advogados de defesa, acusados, policiais, etc - possuem diferentes frações de poderes processuais e responsabilidades em cada sistema. Por exemplo, desde esta perspectiva, o julgador no sistema inquisitorial, como um investigador ativo, possui mais poderes processuais - e.g. para agir sua sponte - que o julgador no sistema adversarial ${ }^{51}$. Isto também significa que tanto a acusação quanto a defesa no sistema inquisitorial são comparativamente menos poderosos do que no sistema adversarial. Um exemplo disso é o poder que a defesa tem no sistema adversarial para realizar a sua própria investigação preliminar - um poder geralmente não presente nos sistemas

\footnotetext{
${ }^{49}$ Sobre a influência que a educação jurídica estadunidense pode ter nos processos de americanização das normas e práticas jurídicas na Europa, Confira Weigend, Americanization, op. cit. nota 3, na 139-40.

50 Esta dimensão de poderes processuais tem sido relativamente negligenciada pelas análises de direito processual penal comparado e é central não apenas por descrever as diferenças entre os sistemas adversarial e inquisitorial, mais também por identificar potenciais focos de resistência às reformas judiciais nos arranjos institucionais adversarial e inquisitorial.

${ }^{51}$ Isto é claro se nós comparamos o juiz ativo do sistema inquisitorial com o júri do adversarial. Os juízes do sistema inquisitorial são também mais poderosos do que os juízes profissionais do sistema adversarial por causa do seu poder de decidir qual prova é produzida no julgamento e a ordem na qual ela é apresentada, assim como através do seu poder de liderar a tomada de depoimento das testemunhas e peritos. Contudo, esta última assertiva deve ser qualificada. Os juízes do sistema adversarial possuem poderes próprios - i.e poderes contra o desacato (contempt powers) que faltam ao sistema inquisitorial. Além disso, uma vez que há menor controle hierárquico sobre as decisões dos juízes do sistema adversarial, o juiz do sistema adversarial também possui mais poderes neste aspecto.
} 
inquisitoriais ${ }^{52}$. A variação dos poderes processuais no nível dos atores individuais também pode ser observada no nível institucional, nas relações de poder entre o Ministério Público, o judiciário, a ordem dos advogados, a defensoria pública, a polícia, etc ${ }^{53}$.

A dimensão dos poderes processuais também possui uma relação de influência mútua com as estruturas de significado e de disposições pessoais. Por exemplo, uma estrutura de interpretação e de significado inquisitorial concede ao juiz amplos poderes de investigação enquanto que concede poderes mais limitados para a acusação e para a defesa. Ao mesmo tempo, contudo, qualquer tentativa de mudar esta estrutura de interpretação e significado geralmente acarretará uma reação dos juízes que protestarão contra a perda de poder através de uma nova estrutura processual de significados ${ }^{54}$.

52 No que concerne à França, Confira, por exemplo, Valérie Dervieux, The French System, in EUROPEAN CRIMINAL PROCEDURES, 218, 250 (Mireille Delmas-Marty \& J. R Spencer eds., 2002).

${ }^{53}$ Apesar de que uma elaboração mais extensiva sobre esta categoria não é necessária para os fins deste artigo, eu também incluo nesta dimensão de poderes processuais e institucionais não apenas a relação entre os principais atores permanentes e instituições do sistema criminal, mas também as relações entre os atores profissionais permanentes e os leigos. No sistema inquisitorial, o poder dos leigos como julgadores é mínimo ou completamente inexistente. No sistema adversarial, é muito mais substancial, ao menos em termos comparativos. Confira e.g ROBERT A. KAGAN, ADVERSARIAL LEGALISM 86-87 (2001).

${ }^{54}$ A implementação do Código de Processo Penal da Província de Buenos Aires de 1998, na Argentina, oferece um exemplo deste fenômeno. Este código passou a responsabilidade da realização da investigação preliminar dos juízes aos promotores. Consequentemente, um grande número resistiu à esta redução dos poderes processuais. Esta resistência se manifestou, por exemplo, na denominada "guerra das fotocópias". Quando requeriam medidas de busca, os promotores investigadores escolhiam submeter aos juízes cópias autenticadas do dossiê escrito que continha a investigação, ao invés dos originais como uma medida de acelerar o procedimento. Contudo, um grande número de juízes considerou isto como uma questão simbólica sobre quem de fato estaria no comando da investigação. Desse modo, eles disseram que não concederiam nenhum mandado de busca até que recebessem o dossiê escrito original. Estas controvérsias arruinaram muitas investigações e se tornaram uma questão tão séria que a Suprema Corte da província teve de intervir. Confira e.g Rafael Saralegui, Demora Judicial en San Isidro por una Disputa, LA NACIÓN (Arg), 6 de junho, na 01, disponível em 
Isto nos leva a um ponto muito importante. Mesmo apesar de ter apresentado as dimensões da estrutura de interpretação e significado, disposições pessoais e poderes processuais e institucionais como analiticamente diferentes, na realidade, eles operam de forma conjunta e tendem a se reforçar, apesar de, às vezes, subverter uns aos outros.

\section{OUTROS ELEMENTOS DOS SISTEMAS}

As interações entre estas três dimensões possuem implicações adicionais.

As estruturas de interpretação e significado adversarial e inquisitorial não são apenas as "lentes" através das quais os atores jurídicos compreendem e atuam na realidade. Elas também constituem duas ordens normativas que indicam, até certo ponto, como os casos deveriam ser resolvidos, quais tecnologias deveriam ser empregadas, como cada um dos atores do sistema deveria se comportar, etc.

Por exemplo, elas determinam, até certo ponto, como recursos materiais e humanos são estruturados e gerenciados. Exemplo disso são as diversas técnicas de gestão de casos que existem em cada sistema. No sistema inquisitorial, um dossiê escrito é a espinha dorsal de todo o processo e uma das principais ferramentas de gerenciamento do processo, desde o primeiro estágio do procedimento, no qual a polícia intervém, até a fase de apelação contra a decisão ${ }^{55}$. Reciprocamente, no sistema adversarial, audiências públicas e orais desempenham um papel importante no gerenciamento dos casos - mesmo naqueles em que há acordo ${ }^{56}$. De uma forma similar - como veremos com maior detalhe adiante - o plea bargaining tem sido uma ferramenta de gerenciamento de casos

http://lanacion.com.ar/Archivo/Nota.asp?nota id=19704 (última visita em 25 de novembro de 2003) (no arquivo com o Harvard International Law Journal).

55 Para uma descrição do papel do dossiê escrito nos sistemas inquisitoriais Confira Rudolf B. Schlesinger, Comparative Criminal Procedure: a Plea for Utilizing Foreign Experience, 26 BUFF. L. REV. 361, 355-67 (1977).

56 Sobre a preferência pela produção oral do testemunho em audiência pública nos Estados Unidos Confira FED. R. CRIM. P.26. Sobre a importância da comunicação oral no processo penal inglês, Confira DAMAŠKA, op. cit. nota 27, na 61. 
praticamente desconhecida nos sistemas inquisitoriais até recentemente ${ }^{57}$, mas tem sido aprovada e amplamente utilizada nas jurisdições angloamericanas. ${ }^{58}$.

Isto não quer dizer, entretanto, que as dimensões de estruturas de significado, disposições pessoais e poderes processuais influenciam a distribuição de recursos humanos e materiais, a ética profissional, os sistemas internos de estímulos, etc., de forma unidirecional. Estes conjuntos de fatores se influenciam mutuamente. Por exemplo, a existência de um dossiê escrito, uma ferramenta de gerenciamento de caso que contem toda a informação colhida durante a fase de investigação preliminar, é necessária para o juiz da instrução se comportar como um investigador ativo ${ }^{59}$. Se este dossiê não existisse por causa, por exemplo, de sua supressão através de uma reforma jurídica, o juiz do julgamento não poderia se comportar de maneira ativa; não poderia organizar o julgamento, consequentemente, tomar o depoimento das testemunhas efetivamente, etc., e as partes ganhariam poderes processuais à sua custa ${ }^{60}$. Uma vez que esta reforma perdurasse no tempo, ela poderia produzir uma mudança nas disposições internas dos juízes, promotores, e advogados no sistema inquisitorial, de forma que estes começariam a agir de maneira

${ }^{57}$ Para uma clássica análise Confira John A. Langbein, Land Without Plea Bargaining: How the Germans Do It, 78 MICH. L. REV. 204 (1979).

58 Para análises históricas sobre como a prática do plea bargaining se desenvolveu nas jurisdições estadunidenses, Confira Albert W. Alschuler, Plea Bargaining and its History, 13 LAW \& SOC'Y REV. 211 (1979); George Fischer, Plea Bargaining's Triumph, 109 YALE L.J 857 (2000); Lawrence M. Friedman, Plea Bargaining in Historical Perspective, 13 LAW \& SOC'Y REV. 247 (1979); John H. Langein, Understanding the Short History of Plea Bargaining, 13 LAW \& SOC’Y REV. 261 (1979). .

${ }^{59}$ Confira e.g Mirjan Damaška, Aspectos globales de la reforma del proceso penal, in REFORMAS A LA JUSTICIA PENAL EN LAS AMÉRICAS (Fundación para el Debido Proceso Legal ed., 1999), disponível em http://dplf.org/Conference98/DAMAŠKA.pdf (última visita em 18 de outubro de 2003).

${ }^{60}$ Esta foi precisamente a ideia por trás do artigo 431 do Código de Processo Penal Italiano de 1989 que eliminou o acesso pleno do juiz instrutor ao dossiê escrito coletado durante a fase de investigação preliminar. Confira CODICE DI PROCEDURA PENALE, art. 431 (2002) Italy (C.P.P). Para uma análise da reforma Confira Grande, op. cit. nota 35 , na $243-44$. 
diversa: os juízes mais passiva, as partes mais ativamente. Esta mudança nas práticas processuais penais (a parole) produziria, então, uma transformação na estrutura inquisitorial de interpretação e significado (a langue) e na dimensão dos poderes processuais.

Considerando estas relações multidirecionais entre as três dimensões descritas e os recursos materiais e humanos, técnicas de gerenciamento de casos, ética profissional, etc., será importante analisar como e por que os processos penais adversarial e inquisitorial mudam ao longo do tempo, incluindo as mudanças produzidas pela transferência de ideias e instituições jurídicas.

\section{E. PONTOS DE ÊNFASE}

Dois pontos finais merecem ser ressaltados. Primeiro, como as categorias adversarial e inquisitorial existem nas práticas processuais penais concretas das jurisdições common e civil law, elas são constantemente desafiadas e submetidas a mudanças. Por exemplo, cada vez que um determinado juiz americano toma ativamente o depoimento de testemunhas (ou autoriza jurados a fazê-lo) há um desafio à estrutura adversarial de interpretação e significado. Não obstante, a circunstância de que tal fato ocorra o tempo todo não significa que os sistemas adversarial e inquisitorial não existam nestas práticas processuais. A concepção mais abrangente do sistema pode ainda ser altamente predominante nestas práticas mesmo que sejam encontradas certas exceções e desafios. Neste sentido, eu não acredito que estas culturas processuais - e a cultura em geral - sejam homogêneas. Minha reivindicação empírica é a de que as culturas processuais adversarial e inquisitorial permanecem altamente predominantes nas jurisdições anglo-americanas e nas jurisdições civil law da Europa Continental e da América Latina respectivamente, mesmo nos dias de hoje, ao menos no que se refere aos procedimentos formais da instrução processual e julgamento.

Segundo, mesmo que as categorias adversarial ou inquisitorial tenham sido altamente predominantes durante os procedimentos formais de instrução processual e julgamento, isto não significa que elas sejam apenas estruturas de interpretação e significado que existem nos sistemas 
de justiça criminal de jurisdições anglo-americanas ou civil law, respectivamente ${ }^{61}$. Apesar da existência dessas outras estruturas de

${ }^{61}$ Abordar este ponto em detalhe está para além do objetivo deste artigo. Mas eu gostaria de realçar quatro pontos principais. Primeiro, há diferenças processuais locais que não podem ser resumidas a estas estruturas globais de significado. Por exemplo, o Ministério Público é parte do Poder Executivo na França, do Judiciário na Itália, e uma instituição independente dos três tradicionais braços do governo, na Argentina. Estas diferentes posições institucionais têm implicações sobre como um promotor deve ser entendido em cada um destes países - e.g. quão independentes eles são do Poder Executivo (para uma análise da relação entre a independência do Ministério Público e a sua posição institucional no contexto da América Latina Confira Philip B. Heymann, Should Latin American Prosecutors be Independent of the Executive in Prosecuting Government Abuses?, 26 U. MIAMI-INTER-AM. L. REV.535 (1995)) - e estas diversas compreensões não podem ser reduzidas às estruturas de significado adversarial e inquisitorial. (Para uma análise das consequências destas diferentes posições dos promotores na França e na Itália Confira Carlo Guarnieri, Prosecution in Two Civil Law Countries: France and Italy, in COMPARING LEGAL CULTURES 183 (David Nelken ed. 1997)). Segundo, em cada jurisdição concreta há normalmente outras estruturas de interpretação e significado no processo penal e, mais amplamente, no sistema de justiça criminal, que compete com ou complementa o adversarial e o inquisitorial. Por exemplo, na maior parte do século XX nos Estados Unidos, a fase de sentenciamento dos procedimentos não foi estruturada ou sobretudo influenciada pelo sistema adversarial, mas ao invés, por uma concepção paternalista dos procedimentos que consideravam o condenado como um perigo ou uma pessoa doente que deveria ser reabilitada (para uma análise da fase de sentenciamento nos Estados unidos durante a maior parte deste século e como ela mudou com a introdução das Guias Federais de Sentença (Federal Sentencing Guidelines) Confira, por exemplo, Kate Stith \&José A. Cabranes, Judging Under the Federal Sentencing Guidelines, 91 NW. U.L. REV. 1247 (1997)). Mesmo na fase de determinação da culpa, onde o sistema adversarial prevaleceu por um longo período nos Estados Unidos, há procedimentos específicos que são organizados de acordo com uma estrutura inquisitorial de significado, como aqueles perante o grande júri. Sobre o caráter inquisitivo do grande júri Confira, por exemplo, Abraham S. Goldstein, Reflections on Two Models: Inquisitorial Themes in American Criminal Procedure, 26, STAN. L. VER 1009, na 1020 (1974).Para uma proposta de introdução de mais proteções adversariais nos procedimentos perante o grande júri, Confira Peter Arenella, Reforming the Federal Grand Jury and the State Preliminary Hearing to Prevent Conviction Without Adjudication, 78 MICH.L.REV 463 (1980). Terceiro, há outras estruturas de interpretação e significado concernentes não apenas ao sistema de justiça criminal, mas também ao sistema jurídico como um todo. Se alguma dessas estruturas pode ser reduzida a distinções globais entre common e civil law - e.g., a argumentação jurídica no primeiro é mais baseada em inferências analógicas e no segundo em dedutivas - há outras 
interpretação e significado que operam nos níveis processual, jurídico e social, seria um equívoco subestimar a grande importância das estruturas adversarial e inquisitorial. As categorias adversarial e inquisitorial exerceram uma influência considerável nas práticas processuais penais, nas normas, nos arranjo organizacionais, nos sistemas de estímulos, etc., nas jurisdições anglo-americanas e civil law, especialmente na fase de instrução processual (phase of determination of guilt or innocence). Mesmo que análises específicas devam prestar atenção nas particularidades locais e nas influências socais, econômicas e políticas sobre o processo penal, seria um erro não observar estas consideráveis diferenças e semelhanças globais. Usando uma metáfora extraída da moderna teoria dos sistemas, seria possível dizer que os sistemas anglo-americano e civil law compartilham, respectivamente, um programa adversarial ou inquisitorial similar ou equivalente, mesmo que esse programa coexista com outros programas jurídicos e sociais em cada jurisdição em particular ${ }^{62}$. Estes programas devem ser conceitualizados adequadamente a fim de analisar as similaridades e diferenças entre as jurisdições anglo-americana e civil law e a circulação de ideias jurídicas e instituições entre elas, bem como discutir as sutilezas da tese da americanização.

diferenças que não podem. Por exemplo, enquanto alguns países possuem um sistema federal outros não, e esta diferença não parece ter origem nos sistemas adversarial e inquisitorial. Finalmente, há também outras estruturas de interpretação e significado (política, econômica, religiosa, midiática, etc.) que excedem a esfera jurídica, mas que podem afetar como os atores do processo penal e da justiça criminal são compreendidos. Por exemplo, o juiz da investigação preliminar - juge d'instruction nos países francófonos, juez de instrucción na América Latina e Espanha - é em muitas ocasiões representado no imaginário social francês como o pequeno oficial que "faz a verdade destacar-se" lutando "contra os poderosos, a força da tinta e do direito contra a do dinheiro e poder", e, ao mesmo tempo, é uma figura emblemática das províncias em sua luta contra Paris. Garapon, op. cit., nota 39 na 497-98. Esta é uma representação social do juiz da investigação preliminar que é tipicamente ausente em outros sistemas inquisitoriais como a Argentina.

62 Confira Gunther Teubner, The Two Faces of Janus: Retbinking Legal Pluralism, 13 CARDOZO L. REV. 1443, 1455 (1992). 


\section{O CONTEÚDO DA DICOTOMIA: ADVERSARIAL VS. INQUISITORIAL}

Tendo explicado os fundamentos dos sistemas adversarial e inquisitorial como categorias teóricas, há dois binários que eu usarei nesta parte para explicar as principais diferenças entre estes sistemas. Primeiro, enquanto o sistema adversarial concebe o processo penal como uma disputa entre acusação e defesa perante um árbitro passivo, o sistema inquisitorial concebe o processo penal como uma investigação oficial levada a cabo por agentes estatais a fim de determinar a verdade. Segundo, enquanto que o julgador no sistema adversarial é um júri que divide seu trabalho com um juiz profissional, o julgador do sistema inquisitorial é um juiz profissional ou um grupo de juízes profissionais que não dividem sua responsabilidade com qualquer outro corpo ${ }^{63}$. Estes binários explicam algumas das principais diferenças entre o sistema adversarial estadunidense e os sistemas inquisitoriais da Alemanha, Itália, Argentina e França.

Tentar definir os sistemas adversarial e inquisitorial para as finalidades do direito comparado é uma tarefa difícil por pelo menos quatro razões diferentes ${ }^{64}$. Primeiro, as diferenças entre os processos penais das tradições common e civil law podem ser rastreadas no século XIII,

63 Como eu explico adiante, juízes profissionais podem compartilhar suas responsabilidades com leigos em tribunais mistos. Contudo, mesmo neste caso, os juízes profissionais normalmente mantém controle do processo de tomada de decisão, uma vez que eles são os atores profissionais e permanentes. Além disso, há apenas um corpo decisório composto por juízes profissionais e leigos, ao invés de dois - o juiz e o júri como no sistema adversarial.

${ }^{64}$ As expressões "acusatório" e "inquisitório" já eram usadas durante o século XII na Europa para "distinguir um processo que requeria o impulso de um querelante para ser movimentado (processum per accusationem) de um processo que poderia ser movido na sua ausência (processum per inquisitionem)". DAMAŠKA, op. cit. nota 26, na 03. O uso moderno destas expressões, que concebe o acusatório e o inquisitorial não apenas como duas formas diversas de se iniciar processos, mas também como dois sistemas processuais abrangentes provavelmente se desenvolveu no século 19. O primeiro exemplo deste uso que tenho conhecimento é o de FAUSTIN HÉLIE, 5 TRAITÉ DE L'INSTRUCTION CRIMINELLE OU THÉORIE DU CODE D'INSTRUCTION CRIMINELLE 47-65 (1853). 
quando Inglaterra e Europa desenvolveram sistemas diferentes para substituir as então dominantes práticas que foram colocadas em uso desde a queda do Império Romano do Ocidente ${ }^{65}$. Estas diferenças evoluíram com o passar do tempo e explicar estas evoluções separadamente está fora dos propósitos deste artigo ${ }^{66}$.

Segundo, como conseqüência de fenômenos como colonização, civilização e modernização, estas duas tradições se expandiram para incluir um considerável número de países com normas jurídicas individuais e práticas variáveis, complicando assim os esforços para capturar as diferenças e as semelhanças entre os sistemas como um todo ${ }^{67}$.

Terceiro, tanto nas jurisdições anglo-americanas quanto naquelas civil law, as expressões "adversarial" (ou "acusatória") ${ }^{68}$ e "inquisitorial"

${ }^{65}$ Para uma descrição do sistema das ordálias, julgamento pelo combate e juramentos predominantes na Europa anteriormente ao século XIII e a explicação de como eles desapareceram Confira ROBERT BARTLETT, TRIAL BY FIRE AND WATER (1986). 66 Uma clássica descrição é a de ADHEMAR ESMEIN, HISTOIRE DE LA PROCÉDURE CRIMINELLE EN FRANCE (1882). Há uma versão em inglês deste trabalho: ADHEMAR ESMEIN, A HISTORY OF CONTINENTAL CRIMINAL PROCEDURE (John Simpson trans., 1968) (1982). Para descrições contemporâneas destes desenvolvimentos Confira FRANCO CORDERO, PROCEDURA PENALE 16101 (2 ed. 1993); JOHN H. LANGBEIN, PROSECUTING CRIME IN RENAISSANCE (1974); JOHN H. LANGBEIN, THE ORIGINS OF ADVERSARY CRIMINAL TRIAL (2003); JOHN H. LANGBEIN, TORTURE AND THE LAW OF PROOF (1977); JULIO B.J. MAIER, 1 DERECHO PROCESAL PENAL \ 5 (2 ed. 1996); JEAN-PIERRE ROYER, HISTOIRE DE LA JUSTICE EN FRANCE: DE LA MONARCHIE ABSOLUE À LA REPUBLIQUE (2 ed. 1996). Eu não me refiro à "evolução" como progresso ou movimento em direção à perfeição, mas simplesmente como mudança ao longo do tempo. Para uma interessante análise acerca do uso deste termo na teoria dos sistemas Confira Gunther Teubner, Legal Irritants: Good Faith in British Law, or How Unifying Law Ends Up in New Divergences, 61 MOD. L. REV. 11, 15-16, 27-32 (1998).

${ }^{67}$ Sobre a expansão da common law no mundo inteiro Confira KONRAD ZWEIGERT \& HEIN KOTZ, INTRODUCTION TO COMPARATIVE LAW 218-37 (3 ed 1998). Para uma descrição de como o sistema inquisitorial foi imposto e desenvolvido na América Latina, Confira MAIER, op. cit. nota 65, \5 (D) (8). Para uma análise destes desenvolvimentos em certos países africanos, asiáticos e centro-americanos, Confira JEAN PRADEL, DROIT PÉNAL COMPARÉ 186-201.

${ }^{68}$ Abraham S. Goldstein tentou estabelecer uma distinção entre os termos "adversarial" como uma forma de se encontrar fatos e implementar normas - e "acusatório" - que 
estão carregadas de conotações políticas e culturais; por exemplo, a tradição adversarial é normalmente associada a concepções liberais ou democráticas enquanto que a tradição inquisitorial é associada a concepções autoritárias de processo penal ${ }^{69}$. Isto levou ao que poderia ser descrito como uma luta retórica pela apropriação destes termos, que por seu turno multiplicou os seus diferentes usos ${ }^{70}$. De fato, como uma consequência destas conotações, "adversarial" e "inquisitorial" tem sido termos centrais ou "significantes flutuantes" através dos quais os atores dos sistemas anglo-americano e civil law tem definido e diferenciado suas próprias identidades, tanto da identidade de outras tradições quanto de seu próprio passado ${ }^{71}$.

incluiria não apenas os procedimentos de julgamento mas também uma concepção de Estado como sendo neutro nas disputas. Contudo, neste artigo, eu considero estes termos como equivalentes. Confira Abraham S. Goldstein, Reflections on Two Models: Inquisitorial Themes in American Criminal Procedure, 26 STAN L. REV. 1009, 1017 (1974).

${ }^{69}$ Para a Argentina, Confira, por exemplo, MAIER, op. cir. nota 66, \5(H)(1)(a)-(b). Para a França, Confira, por exemplo, Jean Pradel, Inquisitoire-Accusatoire: une redoutable complexité, 68 INT'L REV. PENAL L. 213, 215 (1997). Para a Alemanha Confira, por exemplo, CLAUS ROXIN, STRAFVERFAHRENSRECHT \2, na 9-11 (25 th ed 1998). Para a Itália, Confira, por exemplo, LUIGI FERRAJOLI: DIRITTO E RAGIONE: TEORIA DEL GARANTISMO PENALE 576, 655 n. 84 (1989). Para os Estados Unidos Confira, por exemplo, Miranda v. Arizona, 384 U.S 436, 442-443, 459-60 (1966).

${ }^{70}$ Confira Langer, op. cit. nota 26, na 102-14.

71 Nos Estados Unidos, a palavra "adversarial" foi utilizada de forma elogiosa na referência ao processo penal estadunidense, que teve suas origens mais remotas na Inglaterra, nas lutas por direitos contra a monarquia autoritária, lutas que continuaram nas colônias e que finalmente encontraram o seu caminho no Bill of Rights. Nesta construção do adversarial, o inquisitorial se refere aos contemporâneos processos penais da Europa continental que ainda seriam considerados autoritários - e.g. extraindo confissões de maneira coercitiva. Para um exemplo desta construção do adversarial e do inquisitorial nos Estados Unidos Confira Miranda, 384 U.S, na 442-43, 459-60. (Para outro uso destes termos nos Estados Unidos que não é apresentado de uma forma elogiosa e que está focado no papel do juiz em cada um destes sistemas confira, por exemplo, McNeil v. Wisconsin, 501 U.S. 171, 181 n.2 (1991).) Na Europa continental, um dos usos mais difundidos do acusatório e do inquisitório para definir a identidade do seu processo penal moderno é o seguinte. $\mathrm{O}$ acusatório é usado para se referir aos processos penais angloamericanos modernos - e aqueles que predominaram na Europa continental desde a queda do Império Romano do Ocidente até o século XIII - que são normalmente 
Finalmente, mesmo que seja possível identificar diferenças históricas entre os processos penais da common e da civil law que teriam durado até hoje, não é sempre possível reduzir estas diferenças a um princípio justificador comum. Por exemplo, os plea bargains e as regras detalhadas sobre as provas têm sido tradicionalmente associadas ao processo penal anglo-americano e consideradas inexistentes na maioria dos países civil law ${ }^{2}$. Contudo, as explicações históricas e analíticas destas duas características não podem ser reduzidas a uma única fonte. Os plea bargains parecem ter sua origem em um sistema de processo penal compreendido como uma disputa entre as partes, enquanto que as regras detalhadas de prova parecem ter sido principalmente associadas ao uso de um tribunal bifurcado na qual um órgão - o juiz - decide quais provas podem ser introduzidas no julgamento e outro órgão - o júri - decide a culpa ou inocência do acusado ${ }^{73}$.

considerados ineficientes em termos de aplicação da lei; o inquisitorial se refere aos processos penais que predominaram na Europa continental do século XIII ao XIX, que são geralmente caracterizados como autoritários; e os processos penais modernos da Europa continental constituiriam um sistema misto que combinaria o melhor dos dois outros sistemas. Para um exemplo deste uso no início do século XX na França, Confira RENÊ GARRAUD, 1 TRAITÉ THÉORIQUE ET PRATIQUE D'INSTRUCTION CRIMINELLE ET DE PRÓCEDURE PÉNALE 10-22 (1907). Hélie usa o termo de uma forma similar, HÉLIE, op. cit. nota 64, na 47-65. Para um uso contemporâneo destes termos na América Latina confira MAIER, op. cit. nota 66, $\$ 5(\mathrm{H})(1)(\mathrm{a})-(\mathrm{c})$, na 443-54, apesar deste autor ser bastante crítico quanto ao sistema misto. Eu não conheço ninguém mais que analisou o inquisitorial e o adversarial como termos centrais ou significantes através dos quais as identidades dos atores das tradições common e civil law foram definidas. Compreender estes processos de definição de identidade poderia abrir novas portas para a análise de direito processual penal comparado. Por exemplo, eles poderiam ser úteis na compreensão do por que atores europeus e latino-americanos se interessaram em adotar instituições e ideias do sistema anglo-americano ao invés do contrário. Para uma recente análise das tradições jurídicas como identidades Confira $\mathrm{H}$. PATRICK GLENN, LEGAL TRADICTIONS OF THE WORLD (2000).

${ }^{72}$ Confira, e.g LANGBEIN, op. cit. nota 42, na 68-71.

73 Id. na 70-71. Para um estudo dos motivos por que as normas probatórias nas jurisdições anglo-americanas existem na sua forma atual e como elas se relacionam a outras características do sistema anglo-americano Confira MIRJAN R. DAMAŠKA, EVIDENCE LAW ADRIFT (1997). DAMAŠKA não acredita que a existência do júri tenha desempenhado um papel principal como geralmente é pensado. Id. na 26-27. 
DELICTAE, Vol. 2, №3, Jul..-Dez. $2017 \mid \mathbf{5 0}$

Neste artigo eu abordo estas dificuldades da seguinte forma. Primeiro, relativamente ao problema da mudança nos sistemas com o passar do tempo, eu foco nos processos penais do sistema civil law contemporâneos antes deles introduzirem as reformas adversariais específicas analisadas nas partes seguintes. Segundo, com relação à pluralidade de jurisdições que poderiam ser incluídas nas categorias adversarial e inquisitorial, eu escolhi focar em cinco delas. Quando menciono o sistema adversarial eu estou me referindo às jurisdições estadunidenses, e quando menciono o sistema inquisitorial, eu estou fazendo referência aos processos penais da Alemanha, Itália, Argentina e França. Terceiro, no que se refere às conotações políticas dos termos "adversarial" e "inquisitorial", é necessário destacar que eu as uso apenas como ferramentas descritivas para fins de direito comparado. Por último, ao invés de tentar explicar as diferenças entre os sistemas através de um princípio explicativo, eu identifico dois modelos dentro de cada sistema como base de comparação ${ }^{74}$.

O primeiro par de modelos comparativos são o modelo de disputa (uma característica do sistema adversarial) e o modelo da investigação oficial

\footnotetext{
${ }^{74}$ Tendo em vista a minha conceitualização dos sistemas adversarial e inquisitorial como culturas processuais, existe um quinto problema em se atribuir conteúdo a ambas as categorias. Como eu expliquei na Parte II, estas culturas não são completamente homogêneas e nas práticas processuais penais dos Estados Unidos, Argentina, França, Alemanha e Itália é possível se identificar visões diferentes sobre o que caracteriza cada uma destas culturas. Assim, atribuir um conteúdo particular a cada uma destas culturas jurídicas pode silenciar ou suprimir algumas destas visões alternativas e pode contribuir para fazer prevalecer uma visão sobre as demais. A primeira forma de corrigir este problema é reconhecê-lo, em outras palavras, sendo autoconsciente e autorreflexivo sobre ele. Além disso, eu penso que os sistemas adversarial e inquisitorial como eu os defino nesta Parte, têm sido esmagadoramente predominantes nestas cinco jurisdições ao menos durante a fase de instrução processual. Portanto, eu me concentrarei, neste artigo, nestas concepções predominantes do adversarial e do inquisitorial porque elas são as mais úteis na explicação de como a maioria dos atores jurídicos em cada uma destas jurisdições compreende o processo penal, e desse modo, como o plea bargaining foi transformado quando adotado pelos nossos quatro países de tradição civil law. Trabalhos focados em vozes culturais dissonantes em cada uma destas jurisdições e na heterogeneidade das culturas adversarial e inquisitorial seriam muito valiosos, mas eles são parte de um esforço diferente do empreendido neste artigo.
} 
(uma característica do modelo inquisitorial) $^{75}$. De acordo com o primeiro modelo o processo penal é entendido como uma disputa ou competição entre duas partes, acusação e defesa, diante de um julgador passivo. A disputa se concentra em torno da tentativa da acusação provar para além de uma dúvida razoável que o acusado cometeu o crime do qual ele ou ela está sendo acusado. Se a acusação obtém êxito, então ela vence; se ela falha, o acusado ganha.

Muitas características do processo penal anglo-americano podem ser explicadas através deste modelo. Por exemplo, ampla discricionariedade acusatória combina com este modelo porque a acusação, como uma das partes e dona da disputa, pode não acreditar que há controvérsia em determinado caso ou pode decidir que a controvérsia não é digna de persecução e deste modo, não está obrigado a ajuizar a ação ${ }^{76}$. Guilty pleas se encaixam neste modelo porque a defesa, assim como a outra parte da disputa, pode reconhecer que a outra parte está correta e então resolver a disputa; a determinação da culpa ou inocência acaba ${ }^{77}$ e o caso passa para a fase de sentenciamento. Se o processo penal é visto como uma disputa, então a estruturação do processo como dois casos colidentes, competindo entre si, também se enquadra nesta concepção. Sendo assim, nas jurisdições anglo-americanas, cada parte da disputa

\footnotetext{
75 A ideia de disputa e de investigação tem sido utilizada para os fins do direito comparado desde uma longa data. Confira e.g. HÉLIE, op. cit. nota 66, na 53.

${ }^{76}$ Para análises da ampla discricionariedade dos promotores dos Estados Unidos Confira, por exemplo, Normas Abrams, Prosecution: Prosecutorial Discretion, in 3 ENCYCLOPEDIA OF CRIME AND JUSTICE 1272 (Sandorf H. Khadish ed. 1983); Richard S. Frase, The Decision to File Federal Criminal Charges: a Quantitative Study of Prosecutorial Discretion, 47, U. CHI. L. REV.246 (1980); Peter Krug, Prosecutorial Discretion and Its Limits, 50 AM J. COMP. L. 643 (2002); Wayne R. LaFave, The Prosecutor's Discretion in the United States, 18 AM. J. COMP. L. 532 (1970); Robert L. Misner, Recasting Prosecutorial Discretion, 86 J. CRIM. \& CRIMINOLOGY 717 (1996); James Vorenberg, Decent Restraint of Prosecutorial Power, 94 HARV. L. REV.1521 (1981). Para uma análise clássica de como corrigir o problema da discricionariedade no sistema de justiça criminal, relativa não apenas às práticas do Ministério Público mas também às práticas dos atores jurídicos Confira KENNETH CULP DAVIS, DISCRETIONARY JUSTICE: A PRELIMINARY INQUIRY (1969). Arthur Rosett, Discretion, Severity and Legality in Criminal Justice, 46 S.CAL.L REV.12 (1972).

${ }^{77}$ Confira e.g FED. R. CRIM. P. 11(c)(4).
} 
realiza sua própria investigação preliminar $^{78}$, mesmo que as partes precisem revelar (disclosure) parte da informação colhida à outra parte através das regras de descoberta (discovery rules) e procedimentos ${ }^{79}$. O julgamento é dividido em um caso para a acusação e outro para a defesa; as partes normalmente decidem em que ordem serão apresentadas as provas; as testemunhas e peritos pertencem à acusação e à defesa ${ }^{80}$ e o depoimento das testemunhas é desenvolvido como uma disputa entre as duas partes, com exame direto (direct examination) e exame cruzado (crossexamination) bem como o redirecionado (redirect) ${ }^{81}$. Plea bargains também

78 Sobre o dever do advogado de defesa, nos Estados Unidos, realizar investigações razoáveis ou tomar decisões razoáveis sobre a desnecessidade das investigações Confira Wiggins v. Smith, 123 S. Ct 2527 (2003); Strickland v. Washington, 446 U.S 668, 691 (1984).

${ }^{79}$ De fato, até a promulgação do Código de Processo Penal Federal (Federal Rules of Criminal Procedure) em 1946, não havia direito à descoberta (right to discovery). Confira FRANK W. MILLER ET AL., CRIMINAL JUSTICE ADMINISTRATION: CASES AND MATERIALS 753 ( $5^{\text {th }}$ ed.2000). Atualmente, as regras da descoberta estão fundamentadas na Constituição, sob a doutrina Brady, Strickler v. Greene, 527 U.N 263 (1999); Kyles v. Whitley, 514 U.S 419 (1995); United States v. Bagley 473 U.S 667 (1985); United States v. Agurs, 427 U.S 97 (1976); Giglio v United States, 405 U.S 150(1972); Brady v. Maryland, 373 U.S 83 (1963); sobre as leis federais Confira e.g 18 U.S.C $\$ 3500$ (1970), no Código de Processo Penal Federal, Confira e.g FED.R.CRIM.P.12.1, 12.2, 16, e 26.2; e nos poderes de supervisão das Cortes.

${ }^{80}$ Sobre os conselhos que os advogados dão às suas testemunhas nos Estados Unidos Confira, por exemplo, WILLIAM T. PIZZI, TRIALS WITHOUT TRUTH 21-22 (1999). Mas Confira FED. R. EVID. 614(a) (estabelecendo que o tribunal pode, de ofício, convocar uma testemunha); FED. R. EVID. 706(A) (asseverando que o tribunal também pode apontar peritos de sua própria escolha). Estes poderes são raramente utilizados nos julgamentos penais. Confira, e.g United States v. Ostrer, 422, F. Supp. 93 (S.D.N.Y 1976) (asseverando que o tribunal possui poder discricionário para convocar uma testemunha do tribunal; contudo, este poder é raramente invocado). Para uma análise sobre os obstáculos que os juízes encontrariam se tornando mais ativos nos julgamentos Confira Marvin E. Frankel, The Search for Truth: an Umpireal View, 123U.PA.L.REV.1031, 1041-45 (1975).

${ }^{81}$ Confira e.g FED.R. EVID. 611. Federal Rule Evidence (614b) estabelece que "O tribunal pode interrogar testemunhas tanto chamadas de ofício ou por uma parte". Mas este poder não é frequentemente utilizado nos julgamentos criminais. Confira Bradley, op. cit. nota 46, na 421. 
podem ser explicados através do modelo de disputa porque é natural em qualquer disputa que as partes possam negociar uma solução $0^{82}$.

No modelo da investigação oficial, que corresponde ao sistema inquisitorial, o processo penal é visto como uma investigação feita por um ou mais representantes do Estado com o propósito de determinar se ocorreu um crime e se o réu o cometeu ${ }^{83}$. Inúmeros elementos do processo penal em países do sistema civil law podem ser explicados por este modelo ${ }^{84}$. A indisponibilidade do processo por parte da acusação se ajusta a esse modelo porque o processo é a busca pela verdade e, portanto, o caso somente pode ser encerrado quando não há evidência de que tenha ocorrido um crime ou de que o réu o tenha praticado ${ }^{85}$. O conceito de

${ }^{82}$ Confira e.g Brady, 397 U.S 742 (aprovando, pela primeira vez, a constitucionalidade do plea bargaining). Sobre a história do plea bargaining nos Estados Unidos Confira a referências nas obras citadas na nota 58.

${ }^{83}$ Por exemplo, relativamente à busca da verdade como sendo a finalidade do processo penal na França Confira MICHÈLE-LAURE RASSAT, TRAITÉ DE PROCÉDURE PÉNALE 297 (2001).

${ }^{84}$ Recorde-se que esta concepção se refere ao processo penal da Argentina, França, Alemanha e Itália como era antes das reformas que eu analisarei neste artigo. Isto é particularmente importante no caso da Itália, que alterou muitas destas características quando se moveu em direção ao modelo de disputa com a introdução de seu Código de Processo Penal de 1989. Contudo, mesmo que esta descrição se refira às suas préreformas processuais penais, a maioria destas características continua presente na maior parte destes países civil law. Quando eu menciono regras, eu me refiro àquelas que ainda são válidas.

${ }^{85}$ Existem diferenças na forma como as quatro principais jurisdições civil law discutidas neste artigo regulam esta questão. Para jurisdições que estabelecem regras de obrigatoriedade da persecução penal Confira Código Penal (CÓD. PEN.) art. 59.4; Costituzione della Repubblica Italiana (COST.) art. 112. A Alemanha estabeleceu uma norma de persecução penal obrigatória como regra geral, apesar de existirem exceções através do princípio da oportunidade. $\int \$ 152-54$ a STRAFPROZESSORDNUNG (StPO) (Código de Processo Penal). Na França, o promotor tem discricionariedade sobre a ação inicialmente. Mas se o promotor francês decidir exercer a ação, ele/ela não poderá desistir do processo sem o consentimento do tribunal. Confira RASSAT, op.cit. nota 83, na 452-453.(Eu não analisarei aqui os poderes da vítima sobre esta questão). Uma vez que não existe sistema que possa processar todos os crimes, o princípio da obrigatoriedade ou oportunidade (prosecutorial discretion) tem sido descrito como um mito. Para um debate sobre esta questão nos Estados Unidos Confira Abraham S. Goldstein e Martin Marcus, The Myth of Judicial Supervision in Three "Inquisitorial" Systems: France, Italy and Germany, 87, 
guilty plea não existe neste modelo porque, enquanto a admissão da autoria pelo réu pode ser um elemento de prova muito importante, ela não necessariamente fornece uma versão completa da verdade, que caberá ao juiz decidir ${ }^{86}$. Além disso, não há o plea bargaining ${ }^{87}$, não apenas porque não existe o guilty plea, mas também porque a verdade não pode ser negociada nem comprometida. Por fim, o processo é estruturado e compreendido como uma investigação unitária ${ }^{88}$. Sendo assim, existe apenas uma investigação preliminar, aquela feita pelo Estado ${ }^{89}$; no julgamento não há um caso para a acusação e outro para a defesa, apenas o caso do tribunal, e o tribunal decide em que ordem as provas serão apresentadas no julgamento ${ }^{90}$; as testemunhas e os peritos não são das partes e sim do tribunal $^{91}$ e os interrogatórios são iniciados e direcionados pelo tribunal e não pelas partes ${ }^{92}$.

O relacionamento entre os atores do processo nestes dois modelos poderia ser sistematizado da seguinte maneira:

YALE L.J 240 (1977); John H. Langbein \& lloyd Weinreb, Continental Criminal Procedure: "Myth" and Reality, 87 YALE L.J.1549 (1978).

86 Confira Moskovitz, op.cit. nota 41, na 1153. Confira também LANGBEIN, op.cit. nota 42 , na 73-74.

${ }^{87}$ Confira e.g Langbein, op.cit. nota 55.

${ }^{88}$ No que se refere à França Confira, por exemplo, Dervieux, op.cit nota 50, na 250.

${ }^{89}$ Confira Id.

${ }^{90}$ Confira e.g Código Procesal Penal de la Nación (CÓD. PROC. PEN) art. 356. Relativamente à Alemanha, Confira $\iint 155 \mathrm{Nr} 2,244, \mathrm{Nr} 2$ StPO. Confira também ROXIN, op.cit nota $67, \S 15$, na 95.

91 A França é uma exceção porque, durante o julgamento, a testemunha pertence às partes. Confira e.g RASSAT, op. cit. nota 83, na 405-06. Contudo, a testemunha não pode ser instruída e é ainda o juiz presidente que toma o depoimento da testemunha sua sponte ou à requerimento das partes. Confira C. PR. PÉ. Arts 312, 332, 454, 536. Desde $1^{\circ}$ de janeiro de 2001 as perguntas também podem ser realizadas diretamente pelas partes às testemunhas. Confira Dervieux, op.cit, nota 50, 258-259.

${ }^{92} \mathrm{Com}$ relação à Argentina, Confira CÓD.PROC.PEN. art. 389. No que concerne à Alemanha, Confira $\iint 238$ Nr 1, 240, StPO. A seção 239 do StPO afirma que as tomadas de depoimento durante o julgamento deverão ser realizadas diretamente e de forma cruzada se a acusação e a defesa requererem. Contudo, isto é raramente aplicado. Confira ROXIN, op.cit. nota 69, $\mathbb{S} 42$, na 343. 
Modelo de Disputa:

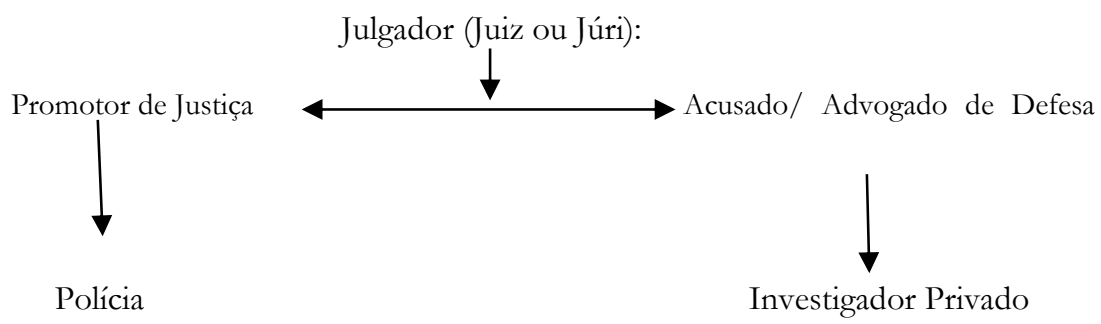

Modelo de Investigação Oficial:

Acusação

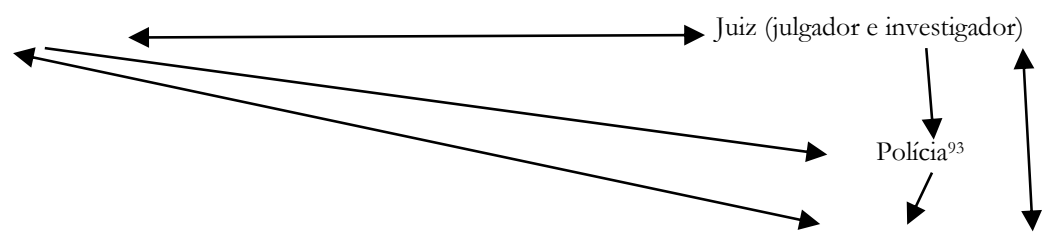

Acusado/Advogado de Defesa

No modelo de disputa, a acusação e a defesa estão no mesmo nível, no sentido de que possuem relativamente os mesmos poderes processuais e de que ambos são como partes que possuem interesses em jogo no caso $^{94}$. Cada um possui seus próprios investigadores - a polícia no

${ }^{93}$ Dependendo da jurisdição civil law, a polícia pode trabalhar sob a supervisão do promotor ou do juiz - geralmente dependendo de quem está encarregado da investigação preliminar, ou de ambos.

${ }^{94}$ Nos Estados Unidos é comum se dizer que o papel do promotor não é apenas buscar uma condenação, mas também justiça. Todavia, em termos comparativos, os promotores estadunidenses agem como partes com um interesse em jogo no caso. Por exemplo, eles geralmente consideram que eles ganham um caso quando o acusado é condenado e perdem o caso quando o acusado é absolvido ou o caso é encerrado fazendo coisa julgada (dimissed with prejudice). Confira Pizzi, op.cit, nota 38. 
DELICTAE, Vol. 2, №3, Jul..-Dez. $2017 \mid 56$

caso da acusação, um investigador particular no caso da defesa. O julgador está acima deles, mas apenas pode tomar decisões sobre o caso até o momento em que as partes ainda acreditarem estar havendo uma disputa.

Também há um acusador no modelo da investigação oficial. Ele ou ela não é visto como uma parte, mas ao invés como outro oficial ou magistrado do Estado cujo papel é descobrir a verdade ${ }^{95}$. Existe uma certa divisão de tarefas entre a acusação e o juiz: o primeiro requer a investigação dos fatos, produção de prova e a aplicação da lei, enquanto o segundo investiga, produz a prova e aplica a lei. Mas ambos são essencialmente o mesmo: oficiais estatais imparciais cujo papel é investigar a verdade ${ }^{96}$. No esquema apresentado, o acusado é representado abaixo do juiz e do acusador, não porque não possua direitos, mas porque possui um interesse em jogo na resolução do caso e porque não é apenas um sujeito de direitos, mas também um alvo da investigação ${ }^{97}$. Não há investigador

${ }^{95}$ Confira Weigend, op.cit, nota 38, na 1233-34.

${ }^{96}$ Confira id.

${ }^{97}$ Muitos doutrinadores têm dito que enquanto no sistema adversarial o acusado é sujeito de direitos, no sistema inquisitorial é objeto de investigação. Isto foi provavelmente verdade há um bom tempo atrás, mas depois da Segunda Guerra Mundial - e até mesmo mais cedo em algumas jurisdições - muitos países inquisitoriais começaram a considerar o acusado sujeito de direitos, ambos em nível normativo - constituições, tratados de direitos humanos, códigos de processo penal - e no nível do direito em ação. Desse modo, na maioria das jurisdições civil law atuais, o acusado é presumido inocente, tem um direito à proibição da auto-incriminação, à assistência de um advogado, etc. Confira Gordon van Kessel, European Perspectives on the Accused as a Source of Testimonial Evidence, 100 W.VA L.REV. 799 (1998). Isto não significa, é claro, que todos os direitos previstos nas normas sejam respeitados na prática. $\mathrm{O}$ argumento que estou tentando demonstrar é o de que o conceito de direitos parece ter perdido parte de seu antigo valor heurístico em estabelecer claras distinções entre sistemas adversariais e inquisitoriais. Por conta disso é que eu não os menciono como uma das diferenças entre os dois sistemas, até mesmo na oposição entre o modelo de disputa e o modelo de investigação oficial, ou na oposição entre os modelos coordenado e hierárquico. De forma parecida, os conceitos de persecução pública versus privada possuem um valor heurístico no passado porque as jurisdições anglo-americanas desenvolveram um sistema de persecução pública muito mais recentemente do que aquelas da civil law. Hoje, a distinção não possui mais um valor heurístico na análise comparativa. Relativamente à influência holandês no desenvolvimento de um acusador público nos Estados Unidos Confira Albert J. Reiss Jr, Public Prosecutors and Criminal Prosecution in the United States of America, 1975, 
particular para a defesa porque há apenas uma investigação oficial conduzida pelo juiz, promotor e polícia. Se a defesa desejar a produção de determinada prova, deve requerê-la ao promotor ou ao juiz ${ }^{98}$.

O segundo par de modelos que eu emprego para capturar as diferenças entre os processos penais da common e civil law é o que o professor Damaška chama de modelos coordenado e hierárquico ${ }^{99}$. De acordo com o professor Damaška, no modelo coordenado a autoridade é exercida pelos julgadores leigos em relações relativamente horizontais de poder entre si, aplicando padrões comunitários nas suas decisões ${ }^{100}$. No modelo hierárquico a autoridade é exercida por julgadores profissionais cujas relações são hierárquicas e que aplicam padrões técnicos em suas decisões ${ }^{101}$.

Eu emprego estes modelos de forma ligeiramente diferente. No modelo coordenado, uma característica do sistema adversarial, eu incluo a participação do leigo através do juri ${ }^{102}$, menor controle hierárquico ${ }^{103}$, uma preferência pela produção oral da prova nos julgamentos ${ }^{104}$, um tribunal bifurcado composto de um órgão leigo (o júri) e um profissional (o juiz), a ausência de uma fundamentação obrigatória do veredito ${ }^{105}$, e detalhadas regras probatórias que filtram os elementos probatórios admitidos no julgamento e que guiam a avaliação da prova que é finalmente introduzida ${ }^{106}$.

JURID.REV.1 (1975). No que se refere à influência francesa no mesmo desenvolvimento Confira ANDRÉ FOURNIER, CODE DE PROCÉDURA CRIMINELLE DE L'ETAT DE NEW YORK 9 (1893).

${ }^{98}$ Confira e.g Dervieux, op.cit nota 52, na 250.

${ }^{99}$ Confira DAMAŠKA, op.cit. nota 27 , na 16-71.

${ }^{100}$ Confira Id. na 17.

${ }^{101}$ Confira Id.

$102 \sigma^{a}$ Emenda à Constituição Estadunidense; Duncas v. Louisiana, 391 U.S 145 (1968).

103 Confira Kepner v United States, 195, U.S 100 (1904) (afirmando que a acusação não pode apelar das absolvições nos Estados Unidos).

${ }^{104}$ Confira e.g FED. R.CRIM.P.26 e FED.R.EVID. 802.

${ }^{105}$ Confira FED. R.CRIM.P. 31.

${ }^{106}$ Confira, e.g FED. R.EVID. 
No modelo hierárquico - parte do processo inquisitorial - eu incluo julgadores profissionais ${ }^{107}$, maior controle hierárquico ${ }^{108}$, aceitação dos elementos de prova colhidos na fase de investigação preliminar e documentada em um dossiê escrito ${ }^{109}$, um tribunal unitário que decide qual

107 A Província de Córdoba na Argentina, França, Alemanha, e Itália possuem tribunais mistos - compostos de juízes profissionais e leigos - para julgar os crimes mais graves. Mas nestes tribunais mistos, os juízes profissionais ainda são os mais influentes julgadores, tendo em vista o seu conhecimento jurídico e experiência, e porque os juízes profissionais e os leigos deliberam conjuntamente. Para uma análise dos tribunais mistos Confira John H. Langbein, Mixed Court and Jury Court: Could the Continental Alternative Fill the American Need?, 1981, AM.B.FOUND.RES. J. 195 (1981). Um número substancial de sistemas inquisitoriais da Europa continental tentou importar o júri no século XIX. O precursor foi a França, que introduziu o júri duas vezes, em 1791 e em 1808. Outros países, como a Alemanha, seguiram o exemplo. Todavia, a maioria dos sistemas inquisitoriais substituiu o júri com tribunais mistos ou então, não possuem nenhum tipo de participação leiga no sistema de justiça criminal (como eu mencionarei adiante, duas exceções são a Rússia e a Espanha, que introduziram o júri em seus respectivos países em 1993 e 1995, respectivamente). Para descrições sobre a introdução do júri na Alemanha e França durante o século XIX, Confira os artigos inclusos em THE TRIAL BY JURY IN ENGLAND, FRANCE, GERMANY, 1700-1900 (Antonio Pado Schioppa ed., 1987). Para uma explicação do por que França e Alemanha finalmente rejeitaram esta instituição e adotaram tribunais mistos, Confira Otto Kahn-Freund, On Uses and Misuses of Comparative Law, in SELECTED WRITINGS, 291, 310 (1978). Para uma análise sobre a virada contra o júri por parte dos atores jurídicos liberais e conservadores após 1900, Confira Benjamin C. Hett, Death in Tiegarten and Other Stories: Murder and Criminal Justice in Berlin, 1891-1933, 343-345 (2001) (tese de Doutorado não publicada, Harvard University). Para uma análise da história do júri na Alemanha e uma conexão com os debates contemporâneos da filosofia política Confira Markus Dirk Dubber, The German Jury and the Metaphisical Volk: From Romantic Idealism to Nazi Ideology, 43 AM. J. COMP. L. 227 (1995).

108 Confira e.g LANGBEIN, op.cit nota 42, na 84-85.

109 Os atuais países da civil law confiam na produção oral da prova em julgamento muito mais do que no passado. Por exemplo, o princípio da imediatidade, próprio da civil law, estabelece que os julgadores, promotores e a defesa devem estar presentes durante a produção da prova que os julgadores utilizarão para prolatar o seu veredito e sentença. Confira e.g MAIER, op.cit nota 66, \ 8(D)(3)(c), na 877-88. Entretanto, os elementos de prova colhidos no dossiê escrito continuam a influenciar os juízes de instrução (trial judges) - que na maioria das jurisdições não participam da investigação preliminar e apenas conhecem tais elementos de prova por conta destes registros escritos. Para uma 
prova é admitida no julgamento e determina o veredito e sentença ${ }^{110}$, a fundamentação escrita do veredito ${ }^{111}$, e poucas regras probatórias para filtrar quais elementos de prova serão introduzidos no julgamento e como eles devem ser avaliados ${ }^{112}$.

Esta descrição dos modelos hierárquico e coordenado é claramente sucinta e esquemática. Todavia, uma descrição mais detalhada de ambas as categorias não é necessária porque eu faço uso limitado delas neste $\operatorname{artigo~}^{113}$. Como ficará claro mais adiante, as categorias centrais para analisar a transferência do plea bargaining do sistema adversarial para o inquisitorial serão os modelos de disputa e de investigação oficial.

\section{REFORMAS RECENTES NO SISTEMA INQUISITORIAL E A TESE DA AMERICANIZAÇÃO.}

Para analisar a tese da americanização, até mesmo em sua forma fraca, alguma elaboração sobre a influência do sistema adversarial sobre o civil law é necessária. Esta parte descreverá tais influências no campo do processo penal. Nas últimas três décadas, dependendo da região e da jurisdição, um considerável número de países civil law introduziu reformas adversariais em seus processos penais inquisitoriais, que vão tanto na direção do modelo de disputa quando na do modelo coordenado ${ }^{114}$.

análise desta questão na Alemanha Confira Mirjan DAMAŠKA, Of Hearsay and Its Analogues, 76 MINN. L. REV.425, 449-52 (1992).

${ }^{110}$ Confira, e.g CÓD. PROC.PEN. arts. 356, 398.

${ }_{111}$ Confira, e.g. COST. Art. 111.6 (que estava vigente mesmo antes da reforma de 1999).

112 Confira e.g ROGER MERLE \& ANDRÉ VITU, II TRAITÉ DE DROIT CRIMINEL 193-194 (5 th. ed. 2001).

${ }^{113}$ Confira, infra, Partes IV e VIII.

114 Nos últimos trinta anos, houve uma tendência da academia jurídica anglo-americana para propor reformas inspiradas na tradição civil law. Contudo, apesar da qualidade destes trabalhos e do fato de que eles foram escritos por renomados acadêmicos, esta tendência tem sido marginal dentro do sistema de justiça criminal estadunidense e não resultou em reformas concretas. Entre os trabalhos acadêmicos que foram inspirados pelo processo penal civil law Confira KENNETH CULP DAVIS, op.cit nota 76, na 191-95; ROBERT 
DELICTAE, Vol. 2, Nº3, Jul..-Dez. $2017 \mid 60$

Movendo-se na direção do modelo de disputa, um considerável número de países da Europa Continental e da América Latina tentou tornar o juiz um ator mais passivo, aumentando a confiança na acusação e na defesa para investigar e conduzir procedimentos. Por exemplo, um número significativo de países eliminou o juiz de investigação ${ }^{115}$ - um símbolo do processo inquisitorial - e tentou substituir esta figura pela investigação preliminar conduzida pela acusação e, em alguns casos, pela defesa ${ }^{116}$. Durante a fase da investigação preliminar o papel do juiz é agora amplamente limitado às decisões sobre a emissão de mandados de busca e apreensão, prisões cautelares e fianças, muito próximo do sistema anglo-

A. KAGAN, ADVERSARIAL LEGALISM 86-87 (2001); J.R.S Spencer, French and English Criminal Procedure, in THE GRADUAL CONVERGENCE, 33-45 (B.S Markesinis ed., 1994); PIZZI, op.cit, nota 80; LLOYD L. WEINREB, DENIAL OF JUSTICE (1977); Albert W. Alschuler, Implementing the Criminal Defendant's Right to Trial: Alternatives to the Plea Bargaining System, 50 U. CHI.L.REV. 931 (1983); Markus Dirk Dubber, American Plea Bargains, German Lay Judges, and the Crisis of Criminal Procedure, 49 STAN. L. REV. 547 (1997); Richard S. Frase, Comparative Criminal Justice as a Guide to the American Law Reform: How Do the French Do It, How Can We Find Out, and Why Should we Care?, 78 CAL. L. REV. 539 (1990); Richard S. Frase \& Thomas Weigend, German Criminal Justice as a Guide to American Law Reform: Similar Problems, Better Solutions? 18 B.C INT'L \& COMP. L. REV.317 (1995); Krug, op.cit. nota 76; Langbein, op.cit, nota 57; Langbein, op. cit. nota 107; Gordon van Kessel, Adversary Excesses in the American Criminal Trial, 67 NOTRE DAME L.REV.403 (1992). Para uma análise do por que não têm existido reformas inspiradas no sistema inquisitorial nos Estados Unidos nos últimos anos Confira John H. Langbein, The Influence of Comparative Procedure in the United States, 43 A.M.J.COMP.L. 545 (1995); John H. Langbein, The Influence of the German Emigrés on American Law: The Curious Case of Civil and Criminal Procedure, in DER EINFLUSS DEUTSCHER EMIGRATEN AUF DIE RECHTSENWICKLUNG IN DEN USA UND IN DEUTSCHLAND 321 (Marcus Lutter et al. eds.,1993).

115 Esta figura é conhecida na França como Juge d'Instruction, o Untersuchungsrichter na Alemanha, o Giudice Istruttore na Itália e o Juez. de Instrucción na América Latina.

116 Por exemplo, a Costa Rica colocou o Ministério Público no encargo da investigação preliminar. Confira o Código Procesal Penal de Costa Rica (CÓD.PROC.PENAL), arts 29091. Contudo, a defesa não pode fazer sua própria investigação preliminar; se a defesa deseja que determinados elementos probatórios sejam colhidos durante a fase da investigação preliminar, ela deve requerer ao Ministério Público esta diligência. Confira CÓD.PROC.PENAL art. 292. Mas no novo processo penal italiano, no qual o Ministério Público é responsável pela investigação preliminar, a defesa pode colher seus próprios elementos de prova durante esta fase. Confira infra notas 167 e 228. 
americano. A Alemanha (1975) ${ }^{117}$, a Itália (1989) ${ }^{118}$, a Guatemala (1994) ${ }^{119}$, as províncias de Buenos Aires e Córdoba na Argentina (1998) ${ }^{120}$, a Costa Rica (1998) ${ }^{121}$, a Venezuela (1999) ${ }^{122}$ e o Chile (2000-2003) ${ }^{123}$, dentre outros tomaram este caminho.

Além disso, algumas jurisdições também alteraram os papeis relativos da acusação e da defesa durante o processo. A Itália, por exemplo, introduziu o exame direto e cruzado nos seus procedimentos ${ }^{124} \mathrm{e}$ permitiu tanto à defesa quanto à acusação arrolar testemunhas ${ }^{125}$. A Itália também estruturou seus processos dividindo-os em um caso para a defesa e um caso para a acusação, como no sistema adversarial estadunidense ${ }^{126}$. Países civil law também começaram a eliminar ou suavizar o princípio da obrigatoriedade da ação penal, outra característica do sistema inquisitorial;

117 Confira ROXIN, op. cit. nota 69, § 72, na 533.

118 Confira, e.g., Giuliano Vassali, Premessa, in ISTITUTO POLIGRAFICO E ZECCA DELLO STATO, PROGETTO PRELIMINARE DEL CODICE DI PROCEDURA PENALE 5, na 6-7 (1988); Ennio Amodio \& Eugenio Selvaggi, An Accusatorial System in a Civil Law Country: The 1988 Code of Criminal Procedure, 62 TEMP. L. REV. 1211, 1218-19 (1989).

119 Confira Luis Rodolfo Ramírez García \& Miguel Ángel Urbina, Guatemala, in LAS REFORMAS PROCESALES PENALES EM AMÉRICA LATINA (daqui para diante apenas LAS REFORMAS) 443, na 458-59, 471-72 (Julio B. Maier el al eds., 2000).

${ }^{120}$ Confira Fabricio Guariglia \& Eduardo Bertoni, Argentina, in LAS REFORMAS, op. cit. nota 119, na 35, 53-54.

121 Confira Daniel González Álvarez, Costa Rica, in LAS REFORMAS, op. cit. nota 119, na 269, 287-88.

122 Confira Sergio Brown Cellino, Venezuela, in LAS REFORMAS, op. cit. nota 119, na $769,803$.

123 Sobre as dificuldades de introduzir estes tipos de reformas em uma jurisdição inquisitorial como o Chile Confira Carlos Rodrigo de la Barra Cousino, Adversarial vs Inquisitorial Systems: The Rule of Law and Prospects for Criminal Procedure Reform in Chile, 5 SW. J.L \& TRADE AM. 323 (1998).

124 Art. 498 do C.P.P.I.

125 Id.

126 Id. arts. 493, 498 do C.P.P.I. 
os exemplos incluem Guatemala $(1994)^{127}$, Costa Rica $(1998)^{128}$ e Chile $(2000-2003)^{129}$.

Importante para este estudo é o fato de que alguns países introduziram mecanismos consensuais inspirados no plea bargaining, incluindo a Alemanha (durante a década de 70), Itália (1989), Guatemala (1994) ${ }^{130}$, Argentina (1998), Costa Rica $(1998)^{131}$ e França (1998).

Também houve consideráveis movimentos em direção ao ideal coordenado. Alguns países introduziram o júri em seu processo penal, como a Rússia (1993) ${ }^{132}$ e a Espanha (1995) ${ }^{133}$. Um número considerável de jurisdições civil law também tentou introduzir mais técnicas orais de gerenciamento de casos do modelo coordenado e reduzir a tradicional importância do dossiê escrito em seus sistemas inquisitoriais. Exemplos dessas jurisdições incluem Itália (1989) ${ }^{134}$, Argentina (sistema federal, 1992) ${ }^{135}$, Guatemala (1994) $)^{136}$, a província de Buenos Aires na Argentina (1998), Paraguai (1999) ${ }^{137}$, Venezuela (1999) ${ }^{138}$ e Chile (2000-2003) ${ }^{139}$.

127 Art. 25 do Cód. Proc. Penal (Guatemala).

128 Art. 22 do Cód. Proc. Penal (Costa Rica).

129 Art. 170 do Cód. Proc. Penal (Chile).

130 Para uma análise deste mecanismo na Guatemala Confira ALBERTO BOVINO, TEMAS DE DERECHO PROCESAL PENAL GUATEMALTECO 141-64.

131 Arts. 373-75 do Cód. Proc. Penal (Costa Rica).

132 Confira Gary Gildin, Trial By jury in the New Russia: a Travelogue, 15 DICK. J. INT'L L. 151 (1996); Steven R. Plotkin, The Jury Trial in Russia, 2 TUL. J. INT'L. \& COMP. L. 1 (1994); Stephen C. Thaman, The Resurrection of Trial by Jury in Russia, 31 STAN. J. INT'L L. 61 (1995). Confira também Leonard Orland, A Russian Legal Revolution: The 2002 Criminal Procedure Code, 18 CONN. J. INT'L 133 (2002) (indicando que o novo Código de Processo Penal da Rússia de Julho de 2002 também inclui o julgamento pelo tribunal do júri nos crimes graves).

133 Confira CARMEN GLEADOW, HISTORY OF TRIAL BY JURY IN THE SPANISH LEGAL SYSTEM 245-85 (2000); Stephen C. Thaman, Spain Returns to Trial by Jury, 21 HASTINGS INT'L \& COMP. L. REV. 241 (1998). Confira também Stephen C. Thaman, Europe's New Jury Systems: The cases of Spain and Russia, 62 LAS \& CONTEMP. PROBS., 233 (1999).

134 Confira e.g Grande, op. cit. nota 35, na 237-39, 257.

135 Confira e.g Guariglia \& Bertoni, op. cit. nota 120, na 64-65.

136 Confira Ramírez García \& Urbina, op.cit nota 119, na 480-481.

137 Confira e.g Alfredo Enrique Kronawetter, Paraguay, in LAS REFORMAS, op. cit. nota 119, na 605, 635-36. 
Com relação tanto ao modelo de disputa quanto ao modelo coordenado, as reformas recentes nas jurisdições civil law parecem confirmar a tese fraca da americanização do processo penal. Entretanto, elas não confirmam necessariamente a tese forte da americanização, que defende que as práticas jurídicas e culturas das jurisdições influenciadas eventualmente se assemelharão ou imitarão seus homólogos estadunidenses. Uma avaliação rigorosa da tese forte requer um estudo mais detalhado de como ideias, regras e instituições jurídicas viajam ou circulam entre sistemas jurídicos bem como as espécies de transformações que ocorrem durante este processo. Em outras palavras, além de estudar e identificar as influências do sistema anglo-americano é necessário compreender como estas influências têm sido traduzidas e que espécies de interações ocorreram entre estas reformas e as práticas preexistentes de recepção nos sistemas de justiça criminal.

\section{A CIRULAÇÃO DE IDEIAS JURÍDICAS: DOS TRANSPLANTES JURÍDICOS ÀS TRADUÇÕES JURÍDICAS.}

Até agora, a metáfora do transplante jurídico - popularizada por Alan Watson - tem sido a metáfora predominante na análise da circulação de instituições jurídicas entre sistemas jurídicos ${ }^{140}$. Através de vários livros e artigos Watson demonstrou que a transferência, empréstimo e a imposição de regras jurídicas têm sido comuns desde tempos imemoriais e ele usou a metáfora do transplante para explicar tais ocorrências ${ }^{141}$. O sucesso da

138 Confira e.g. Brown Cellino, op. cit. nota 122, na 806-07.

${ }^{139}$ Confira Riego, Chile, in LAS REFORMAS, op. cit. nota 119, na 167, 179.

140 Confira e.g. ALAN WATSON, THE EVOLUTION OF LAW (1985); WATSON, op. cit. nota 25; ALAN WATSON, SOCIETY AND LEGAL CHANGE (1977); Alan Watson, Aspects of Reception of Law, 44 AM. J. COMP. L. 335 (1995).

$141 \mathrm{O}$ trabalho de Watson deveria ser lido parcialmente como uma intervenção nos debates sobre a autonomia do direito. $\mathrm{Na}$ análise histórica, Watson tentou demonstrar que o direito não é um espelho da cultura social, sociedade ou economia, mas ao invés disso, que o direito muda como uma consequência de seus desenvolvimentos internos, 
proposta de Watson é atribuível a inúmeras causas e vários doutrinadores em diversos campos do direito adotaram-na ${ }^{142}$. Apesar disso, nesta parte, eu questiono a adequação da metáfora na discussão da circulação de instituições jurídicas e proponho o modelo da tradução jurídica como um novo dispositivo heurístico para abordagem destas questões.

Existem várias razões para o sucesso da metáfora do transplante. Primeiro, o aumento considerável na circulação de ideias jurídicas e instituições por causa da globalização ${ }^{143}$, criou necessidade e interesse de conceitualizar este fenômeno; a popularidade da metáfora do transplante é devida, em parte, à necessidade de se preencher a lacuna entre teoria e prática. Segundo, a metáfora do transplante é poderosa por causa de sua

nos quais o transplante de regras jurídicas tem um papel central. Desta forma, Watson tenta desafiar as análises críticas à la Montesquieu, marxismo e perspectivas "direito \& sociedade" (law and society). Para avaliações críticas da intervenção de Watson Confira Richard L. Abel, Law as Lag: Inertia as a Social Theory of Law, 80 MICH. L. REV. 785 (1982); William Ewald, The American Revolution and the Evolution of the Law, 42 AM. J. COMP. L. 489 (1995).

142 Confira e.g. Ajani, op. cit. nota 25; Berkowitz et al., op. cit. nota 25 na 05; BUSCAGLIA \& RAFLIFF, op. cit nota 25; Ugo Mattei, op. cit nota 25; Frederick Schauer, op. cit. nota 25.

143 Confira e.g Lawrence Friedman, Erewhon: The Coming Global Legal Order, 34 STAN. J. INT'L. L. 347 (2001). A globalização tem sido caracterizada pelo aumento da circulação de bens e serviços assim como a informação. Confira mais genericamente SASKIA SASSEN, GLOBALIZATION ANS IT'S DISCONTENTS: ESSAYS ON THE NEW MOBILITY OF PEOPLE AND MONEY (1998). Para introduces gerais aos debates da globalização Confira, por exemplo, THE ETHICAL DIMENSIONS OF GLOBAL CHANGE (Barry Holden ed., 1996); GLOBAL CULTURE: NATIONALISM, GLOBALIZATION, AND MODERNITY (Mike Featherstone ed. 1990); GLOBAL DEMOCRACY: KEY DEBATES (Barry Holden ed., 2000); THE GLOBAL TRANSFORMATIONS READER: AN INTRODUCTION TO THE GLOBALIZATION DEBATE (David Held \& Anthony McGrew eds., 2000); THE GLOBALIZATION READER (Frank J. Lechner \&John Boli eds. 2000); GLOBALIZING INSTITUTIONS: CASE STUDIES IN REGULATION AND INNOVATION (Jane Jenson \& Boaventura de Sousa Santos eds., 2000); GOVERNANCE IN A GLOBALIZAING WORLD, op. cit. nota 25. Sobre as tendências dos efeitos potenciais da globalização na relação entre a soberania estatal e o direito internacional Confira Kal Raustiala, The Architecture of International Cooperation: Transgovernmental Networks and the Future of International Law, 43 VA. J. OF INT'L L. 1 (2002). 
natureza comparativa inerente: o transplante, como uma metáfora médica ou botânica, pressupõe um corpo ou um ambiente original e um receptor. Sendo assim, a metáfora permite a comparação entre os sistemas jurídicos originais e receptores bem como a comparação entre as instituições, ideias ou regras jurídicas originais e transplantadas. Esta pode ser uma abordagem particularmente interessante para o direito comparado e uma forma útil de analisar os fenômenos das influências das culturas jurídicas como a americanização - e outras teses relativas às tendências da globalização jurídica (como a tese da convergência) ${ }^{144}$. Finalmente, a ideia do transplante também é poderosa porque, como uma metáfora médica e botânica, ela inclui a necessidade de adaptação das regras jurídicas transferidas ao novo organismo ou ambiente - as práticas de um sistema jurídico existente - e, ao mesmo tempo, a possibilidade de rejeição do organismo ou ambiente receptor - o sistema jurídico receptor ${ }^{145}$.

Apesar disso, a metáfora do transplante jurídico apresenta diversas limitações. Ela falha na explicação de que, em muitos casos, as práticas e conceitos jurídicos são transferidos em alguns níveis conceituais mas não em outros. Por exemplo o controle de constitucionalidade é uma ideia e um mecanismo institucional que foi "transplantado" dos Estados Unidos para a Europa Continental ${ }^{146}$. Contudo, o sistema de controle de constitucionalidade na Europa Continental difere substancialmente da versão americana: (a) enquanto nos Estados Unidos todo tribunal pode

144 Confira THE GRADUAL CONVERGENCE (B. S. Markesinis ed., 1994); Pierre Legrand, European Legal Systems Are Not Converging, 45 INT'L \& COMP. L.Q. 52 (1996). Para uma discussão da tese da convergência no processo penal, Confira, por exemplo, Diane Marie Amann, Harmonic Convergence? Constitutional Criminal Procedure in an International Context, 75 IND. L.J. 809 (2000); Craig M. Bradley, The Convergence of the Continental and the Common Law of Criminal Procedure, 7 CRIM. L.F 471 (1996) (revisando CRIMINAL JUSTICE IN EUROPE: A COMPARATIVE STUDY (Phil Fennell et al eds., 1995); Nico Jorg et al., Are Inquisitorial and Adversarial Systems Converging? In CRIMINAL JUSTICE IN EUROPE, op. cit.

145 De forma não surpreendente, o mais interessante debate sobre os transplantes legais durante a década de 70 se deu sobre a potencial rejeição das ideias e regras jurídicas transplantadas. Compare Otto Kahn-Freund, Legal Transplants and Law Reform, 92 LAW. Q. REV. 79 (1976).

${ }^{146}$ Confira Blankenburg, op.cit. nota 19. 
declarar certas regras ou práticas estatais inconstitucionais, na Europa Continental, normalmente apenas um Tribunal Constitucional centralizado pode fazê-lo; (b) enquanto nos Estados Unidos os tribunais que realizam a função de controle de constitucionalidade são parte do Judiciário, na Europa Continental não é sempre assim ${ }^{147}$.

A metáfora do transplante não é flexível o suficiente para capturar estas sutilezas e transmite a noção enganosa de que os mesmos conceitos e práticas do "controle de constitucionalidade" existem tanto nos Estados Unidos quanto na Europa Continental. Um rim ou uma muda de planta se parecerão em seu corpo ou ambiente original e receptor, mas isto normalmente não ocorre com ideias e instituições jurídicas, que são imitadas até certos níveis conceituais, mas não em outros.

Outro problema com a metáfora do transplante é que mesmo que os reformadores tentem imitar a ideia ou prática jurídica tão próximo quanto possível, esta nova ideia jurídica pode ainda ser transformada pelas estruturas de significado, disposições individuais, arranjos institucionais e de poder, sistemas de estímulos, etc., presentes no sistema jurídico receptor $^{148}$. Por exemplo, como discutido anteriormente, os reformadores italianos tentaram importar um processo adversarial através da introdução do princípio de que a prova produzida em julgamento deve ser requerida pelas partes ao invés de que a sua produção seja ordenada pelo juiz ${ }^{149}$.

147 Para uma análise do Conselho Constitucional Francês Confira, por exemplo, Doris Marie Provine, Courts in the Political Process in France, in COURTS LAW, AND POLITICS 177, 190-93.

148 Esta é a razão pela qual Pierre Legrand sustentou que transplantes jurídicos são impossíveis. O sentido de uma regra jurídica não é determinado - ou não somente determinado - pelas palavras que expressam a regra, mas pelo restante do contexto de significado - i.e. o sistema jurídico - no qual esta regra está situada. Portanto, toda vez que palavras que expressam uma regra jurídica são transferidas de um sistema jurídico A para um sistema jurídico B, o sentido destas palavras mudará porque não há dois sistemas jurídicos exatamente iguais no contexto de significado. A transformação da regra transferida - e assim a impossibilidade do transplante jurídico - será ainda maior quando se der de um sistema common law para outro civil law ou vice-versa, considerando as tradicionais profundas diferenças entre as duas espécies de sistemas jurídicos. Confira Pierre Legrand, The Impossibility of 'Legal Transplants', 4 MAASTRICHT J. EUR. \& COMP. L. 111 (1997).

${ }^{149}$ Arts. $190.1,493.1$ e 495.1 do C.P.P.I. 
Contudo, o Código de Processo Penal também previu uma exceção a este princípio permitindo ao tribunal, se absolutamente necessário, ordenar, mesmo sua sponte, a produção da nova prova ${ }^{150}$. Enquanto esta exceção não é inusual nas regras de processo americanas ${ }^{151}$, ela é raramente exercida pelos juízes americanos ${ }^{152}$. Ainda na Itália, devido ao fato de inúmeros atores jurídicos estarem acostumados ao modelo inquisitorial (e desse modo possuem um conjunto de disposições internas predominantemente inquisitorial) esta exceção tem sido interpretada como concedendo ao tribunal um amplo alcance para ordenar novas provas ${ }^{153}$. O resultado parece ser um processo que por vezes é interpretado através do modelo de disputa - como foi originalmente vislumbrado pelos reformadores - mas é frequentemente interpretado e compreendido através do modelo de investigação oficial ${ }^{154}$.

Considerando o quadro teórico desenvolvido na parte II, esta transformação não é surpreendente em um país como a Itália, onde o sistema inquisitorial foi claramente predominante como uma estrutura de interpretação e significado, nas disposições individuais da maioria dos atores jurídicos e na distribuição dos poderes processuais. Contudo, o ponto que eu quero enfatizar aqui é que a metáfora do transplante parece ser, de novo, muito rígida para capturar as transformações pelas quais passou o processo estadunidense, submetido na Itália, como uma consequência de suas interações com as práticas de justiça criminal predominantemente inquisitoriais preexistentes.

Um terceiro problema com a metáfora do transplante é que a transferência das regras, ideias e práticas jurídicas pode produzir uma

\footnotetext{
150 Art. 507 C.P.P.I.

${ }^{151}$ Confira e.g. FED. R. EVID. 614(a).

152 Confira United States v. Ostrer, 422 F. Supp., 93 (S. D.N.Y, 1976) (asseverando que apesar do tribunal possuir poderes discricionários para convocar testemunhas, o poder é raramente utilizado).

${ }^{153}$ Confira e.g. Corte Costituzionale, 24 mar. 1993, n.111, Raccolta ufficiale delle sentenze e ordinanze delle Corte costituzionale (Racc. Uff. Corte cost.) 1993, vol. 106, 733 (Azzari); Cass. Pen., sez. un., 28 dic. 1999, n. 5549 (Paternò); Cass, Pen. sez. un.6 nov. 1992, n. 11227, (P.M in proc. Martin), in CASSAZIONE PENALE 1993, vol. 33, 280, n. 157; Grande, op.cit nota 35, na 246 (citando decisões adicionais).

${ }^{154}$ Confira Grande, op.cit. nota 35, na 246-47.
} 
transformação profunda não apenas na prática transferida mas também no sistema jurídico receptor como um todo. No exemplo anterior, não apenas o processo de julgamento estadunidense importado foi transformado em seu novo contexto italiano, mas ele também introduziu alguns elementos de disputa no sistema italiano. Se estes elementos forem incorporados nas disposições internas dos juízes, promotores e advogados de defesa isto poderá produzir mudanças em um sistema onde a estrutura de significado inquisitorial tem sido claramente predominante; isto pode, por seu turno, redefinir a forma como o poder é distribuído entre os atores jurídicos. A metáfora do transplante não parece ser suficientemente flexível para capturar este fenômeno também ${ }^{155}$. Mesmo que um corpo humano tenha que se ajustar a um novo órgão, ele irá permanecer essencialmente o mesmo. As mudanças produzidas em um sistema jurídico pela transferência de regras, ideias e instituições jurídicas, entretanto, podem ir muito além disso.

Como uma consequência das limitações da metáfora do transplante jurídico, Günther Teubner propôs a expressão “irritação jurídica” para capturar este fenômeno ${ }^{156}$. A metáfora da irritação jurídica claramente evita a maioria dos problemas associados à metáfora do transplante. Particularmente, ela é capaz de transmitir a ideia de que a transferência de uma regra jurídica ou doutrina pode induzir uma série de transformações nos sistemas jurídico e social receptores. Contudo, a metáfora da irritação jurídica apresenta limitações importantes; a principal delas é que ela perde a dimensão comparativa que fez a metáfora do transplante tão poderosa. Uma irritação não precisa vir necessariamente de outro sistema (jurídico) ou de fora do sistema que a irrita. Consequentemente, a dimensão comparativa da metáfora é perdida no que se refere aos sistemas original e receptor e quanto à prática ou ideia original e a transferida.

Dadas as limitações das metáforas do transplante e da irritação, eu proponho a metáfora da tradução como um dispositivo heurístico superior

\footnotetext{
155 Compreendido em termos botânicos, a metáfora do transplante pode ser mais hábil para responder a esta crítica específica. O transplante de certas espécies do ambiente A para o ambiente B pode produzir mudanças profundas no futuro.

156 Teubner, op. cit. nota 48.
} 
para analisar a circulação de ideias, regras, práticas e instituições jurídicas ${ }^{157}$. A metáfora da tradução mantém a dimensão comparativa que fez a metáfora do transplante tão poderosa e que falta à metáfora da irritação jurídica. No que se refere aos sistemas jurídicos, a metáfora da tradução distingue a linguagem fonte ou sistema jurídico - de onde a ideia ou instituição jurídica vem - da receptora - para a qual a ideia ou instituição jurídica é traduzida ${ }^{158}$. A metáfora da tradução também permite uma distinção entre o "texto" original - a ideia ou instituição jurídica como desenvolvida no sistema jurídico fonte - e o texto traduzido.

Ao direcionar nossa atenção para as diferenças entre os textos original e traduzido, a metáfora da tradução também se distingue das transformações que a ideia jurídica pode sofrer quando inicialmente

157 A metáfora da tradução não tem sido utilizada nas abordagens da circulação das ideias, regras, práticas e instituições entre sistemas jurídicos, apesar de diversos doutrinadores terem usado a metáfora para a análise de outros fenômenos jurídicos. Confira e.g. JAMES BOYD WHITE, JUSTICE AS TRANSLATION: AN ESSAY IN CULTURAL AND LEGAL CRITICISM (1990); Gerald Torres, Translation and Stories, 115 HARV. L. REV. 1362 (2002). Lawrence Lessig usou a metáfora para propor uma nova teoria da interpretação constitucional. Confira Lawrence Lessig, Fidelity and Constraint, 65 FORDHAM L.REV. 1365 (1997); Lawrence Lessig, The Puzzling Persistence of Bellbottom Theory: What a Constitutional Theory Should Be, 85 GEO.L.J. 1837 (1997); Lawrence Lessig, Translating Federalism: United States v. Lopez, 1995 SUP. CT. REV. 125 (1995); Lawrence Lessig, Understanding Changed Readings: Fidelity and Theory, 47 STAN L. REV. 395 (1995). Para descrições críticas da proposta de Lessig Confira, por exemplo, Steven G. Calabresi, The Tradition of the Written Constitutions: A Comment on Professor Lessig's Theory of Translation, 65 FORDHAM L. REV. 1435 (1997); Michael C. Dorf, Recipe for Trouble: Some Thoughts on Meaning, Translation and Normative Theory, 65 FORDHAM L. REV. 1857 (1997); Sanford Levinson, Translation: Who Needs It?, 85 GEO L.J. 1457 (1997).

158 Pierre Bourdieu fez uma distinção entre o campo da produção e o campo da recepção a fim de capturar a circulação de ideias entre países em áreas como a filosofia, ciências sociais e literatura. Confira Pierre Bourdieu, The Social Conditions of The International Circulation of Ideas, in BOURDIEU: A CRITICAL READER, 221 (Richard Shusterman ed., 1999). A distinção entre produção e recepção tem sido amplamente utilizada nas análises jurídicas. Confira e.g. LA RÉCEPTION DES SYSTÉMES JURIDIQUES: IMPLANTATION ET DESTIN (Michael Doucet \& Jacques Vanderlinden eds., 1994); Diego López-Medina, Comparative Jurisprudence: Reception and Misreading of Transnational Legal Theory in Latin America 7-12 (2001) (Dissertação de doutorado não publicada, Harvard University); MAIER, op. cit. nota 66, \5 (D)(5), D(8), na 303, 329 e \8(A), na 811. 
transferida do sistema jurídico fonte para o sistema jurídico alvo ${ }^{159}$. O primeiro conjunto de transformações surge nas habilidades e decisões dos tradutores ${ }^{160}$, i.e, reformadores jurídicos ${ }^{161}$. A teoria e a história da tradução apresentaram três perspectivas principais: (1) literalismo estrito, uma adequação "palavra-por-palavra" entre os textos original e transferido; (2) "uma reprodução fiel porém autônoma", onde o tradutor ainda tenta ser fiel ao original, mas ao mesmo tempo compõe um texto igualmente poderoso na língua alvo; e (3) recriação substancial, variações, etc., onde a ideia de fidelidade ao original é enfraquecida ou desaparece, e o foco é criar um texto que é poderoso ou apelativo na língua alvo ${ }^{162}$. Considerando os exemplos examinados nesta parte, a tradução dos Estados Unidos para a Itália do princípio de que a prova é produzida no processo pelo requerimento das partes, ao invés de ordem do juiz sua sponte, fica entre a primeira e a segunda abordagens ${ }^{163}$. A tradução da prática estadunidense do controle de constitucionalidade para o contexto da Europa Continental se aproxima mais da terceira abordagem.

O segundo conjunto de transformações iniciais de texto pode ter sua origem nas diferenças entre as línguas fonte e alvo - as estruturas de interpretação e significado das línguas fonte e alvo. Por exemplo, a palavra "derecho" em espanhol significa tanto "right" como "law" em inglês.

$159 \mathrm{Eu}$ me refiro aqui às transformações das ideias ou instituições jurídicas quando inicialmente transferidas ao sistema jurídico alvo. Como veremos, há transformações que acontecem assim que a ideia ou instituição é incorporada no sistema jurídico alvo.

160 As habilidades do tradutor podem incluir não apenas a sua habilidade para traduzir textos (jurídicos) mas também o conhecimento da fonte sistema (jurídico). Para uma clássica referência à esta questão Confira John Dryden, On Translation, in THEORIES OF TRANSLATION 17, 30 (Rainer Schulte \& John Biguenet eds., 1992).

${ }^{161}$ A análise do trabalho dos tradutores e suas decisões e motivações é útil para explicar não apenas as transformações que o texto original pode sofrer mas também por que a tradução - i.e. a reforma jurídica - aconteceu em primeiro lugar. Há uma tendência recente nos estudos de tradução para priorizar as motivações e poderes dos tradutores. Confira. e.g. SUSAN BASSNETT, TRANSLATION STUDIES 6, 10 (3 ed. 2002); LAWRENCE VENUTI, THE TRANSLATOR'S INVISIBILITY (1995).

162 Confira GEORGE STEINER, AFTER BABEL: ASPECTS OF LANGUAGE AND TRANSLATION 266 (3 ed. 1998).

163 Id. na 266 ("As linhas divisórias entre os três tipos estão borradas".). Contudo, a distinção entre os três tipos ainda são úteis para analisar os processos de tradução. 
DELICTAE, Vol. 2, №3, Jul..-Dez. $2017 \mid 71$

Portanto, se nós quisermos traduzi-la do espanhol para o inglês, algo provavelmente será perdido ao se escolher apenas um dos dois significados da palavra ${ }^{164}$.

Além disso, a metáfora da tradução também captura as transformações que a prática ou ideia jurídicas podem sofrer em suas trocas com o sistema jurídico alvo depois de sua tradução inicial. Estas transformações podem incluir a neutralização total do "texto" traduzido a regra ou prática jurídica - pelo ostracismo (desuso) ${ }^{165}$ ou censura (e.g, declarando que a prática é inconstitucional ${ }^{166}$. Além disso, estas transformações podem também incluir uma batalha entre diferentes atores e grupos no sistema jurídico alvo sobre o significado da instituição traduzida $^{167}$.

${ }^{164}$ Para uma análise dos obstáculos que as diferenças entre as línguas oferecem para os tradutores Confira, por exemplo, Roman Jakobson, On Linguistic Aspects of Translation, in THEORIES OF TRANSLATION 144, 146-51 (Rainer Schulte \& John Biguenet eds, 1992). A ideia de intraduzibilidade linguística tem sua origem nestes obstáculos porque ela assume que estas diferenças entre as línguas torna a tradução impossível. Entretanto, a maioria dos estudos de tradução rejeita a ideia de intraduzibilidade. Confira e.g. Hugo Friedich, On the Art of Translation. In THEORIES OF TRANSLATION, op. cit. na 11, $14-15$.

165 Um exemplo deste caso de neutralização é a seção 239 da StPO, que assevera que as tomadas de depoimento em julgamento deverão se desenvolver através do exame direto e cruzado a requerimento da acusação e da defesa, uma regra traduzida do sistema adversarial anglo-americano. Contudo, esta regra é raramente aplicada uma vez que, de acordo com Roxin, ela não se encaixa em nenhuma estrutura do processo penal alemão por que ela retira o controle do processo do juiz presidente. Confira ROXIN, op. cit. nota $69, \S 42$, na 343.

${ }^{166}$ Um exemplo disso é a "tradução" de 1989 das regras de prova para o processo penal italiano, como a proibição da prova de ouvir dizer (bearsay evidence), que permitiu o uso, durante o julgamento, dos depoimentos colhidos na fase de investigação preliminar apenas para propósitos de impedimento (impeachment). A Corte Constitucional Italiana, em sua decisão 255/1992 declarou inconstitucional o art. 500.3 que introduziu esta limitação à prova. Corte cost. 18 mag. 1992, n. 255, 104 Racc. Uff. Corte cost. 1992, 7 (daqui para diante apenas Decisão 255/1992). Para uma análise mais detalhada desta questão Confira infra, nota 226.

167 Por exemplo, a prática norte-americana da equipe de defesa realizar a sua própria investigação preliminar foi traduzida para as práticas italianas em 1989. D.I.vo lug.1898, n.271, art.38, Raccolta Ufficiale degli Atti Normativi della Repubblica Italiana (Racc. Uff). 1989, vol. 8, 3772, 3780, publicado na Gazzetta Ufficiale della Repubblica Italiana (Gazz. 
Por fim, a metáfora da tradução é também apta a descrever a transformação que as práticas linguísticas e sociais receptoras podem sofrer sob a influência do texto traduzido ${ }^{168}$. Considere a influência que a tradução de textos de pensadores como Beccaria, Montesquieu e Voltaire para o inglês produziu, não somente no vocabulário político, mas também no pensamento político da América revolucionária ${ }^{169}$. Igualmente, a tradução para o francês dos Commentaries on the Law of England (1765) de Blackstone teve um impacto não somente no vocabulário jurídico francês como também resultou em uma consideração positiva do sistema inglês pelos atores franceses, o que culminou com a importação do tribunal do júri dois anos após a Revolução Francesa ${ }^{170}$. A tradução de ideias e instituições jurídicas entre sistemas jurídicos também pode ter um impacto não apenas no vocabulário como também nas práticas reais do sistema

Uff.) 5 ago 1989, n. 182 (daqui para diante Law 271/1989). Uma vez que estas práticas surgiram contra a estrutura inquisitorial de significado e contra as disposições internas de um grande número de atores jurídicos, estes atores interpretaram que os elementos de prova colhidos pelo advogado de defesa tinham menor valor probatório do que aqueles coletados pelo promotor. Reciprocamente, aqueles que apoiavam a reforma adversarial sustentaram que os elementos de prova colhidos pela defesa tinham o mesmo valor probatório do que aqueles colhidos pela acusação. Este último entendimento das práticas traduzidas prevaleceu com a sanção dos arts. 391-bis-decies do C.P.P, na D.I vo 7 dic. 2000, n. 397, publicada na Gazz. Uff. 3 gen. 2001, n. 2. (daqui para diante apenas Law $397 / 2000)$.

${ }^{168}$ Certo número de estudos de tradução recentes enfocou este assunto e têm mostrado as transformações que os textos traduzidos podem causar nas práticas sociais e linguísticas receptoras. Confira e.g., Lin Kenan, Translation as a Catalyst for Social Change in China, in TRANSLATION AND POWER, 160 (Maria Tymockzo \& Edwin Gentzler eds. 2002); Alexandra Lianeri, Translation at the Establishment of Liberal Democracy in Nineteenth-Century England: Constructing the Political as an Interpretative Act, in TRANSLATION AND POWER, op. cit. no 1.

169 Sobre a influência que estes pensadores tiveram na América da Revolução Confira BERNARD BAILYN, THE IDEOLOGICAL ORIGINS OF THE AMERICA'S REVOLUTION 26-30 (versão ampliada 1992).

170 Sobre a tradução dos Comentários de Blackstone aos franceses e sua influência na percepção positiva do sistema inglês por um grande número de atores franceses Confira Antonio Padoa Schioppa, I Philosophes e la Giuria Penale, I-II NUOVA RIVISTA STORICA 107, 123-28. 
DELICTAE, Vol. 2, №3, Jul..-Dez. $2017 \mid 73$

receptor - i.e, aproximando as práticas inquisitoriais anteriores na direção do sistema adversarial.

\section{O PLEA BARGAINING COMO UM CAVALO DE TROIA DO SISTEMA ADVERSARIAL.}

O plea bargaining americano é um mecanismo processual no qual a acusação e a defesa podem entrar em acordo sobre o caso, sujeito à homologação judicial ${ }^{171}$. O acordo pode se apresentar de diversas formas, mas normalmente consiste em o réu se declarar culpado de um crime ou de diversos crimes. Em troca, a acusação deixa de lado outras acusações, aceita que o réu se declare culpado de crimes de menor gravidade ou requer - ou não se opõe - que o réu receba determinada sentença ${ }^{172}$.

A importação do plea bargaining exemplifica a tradução de uma prática jurídica que poderia potencialmente americanizar as jurisdições de cunho inquisitorial. Há poucos mecanismos e institutos mais característicos do sistema adversarial estadunidense e mais especificamente do modelo de disputa ${ }^{173}$. O plea bargaining estadunidense, por definição,

171 Confira e.g. FED. R. CRIM. P. 11(e).

172 Confira e.g. FED. R. CRIM. P. 11(e)(1).

173 Relembro que neste artigo eu uso o termo "adversarial" de uma forma descritiva. No nível descritivo, uma vez que o plea bargaining é amplamente utilizado no sistema estadunidense, é razoável considerar esta prática altamente característica do processo penal dos Estados Unidos. Ademais, esta prática também se encaixa bem na concepção de processo penal como uma disputa entre partes diante de um árbitro imparcial, uma concepção que faz parte do sistema de justiça criminal estadunidense. Se ao invés de utilizar esta expressão de uma forma descritiva, entender-se o sistema adversarial como um modelo normativo o prescritivo - com o que, por exemplo, todos ou a maior parte dos casos deveriam ser decididos por um julgamento pelo júri - se consideraria que os plea bargains não seriam parte do sistema adversarial estadunidense, mas ao contrário, uma forma de lhe minar. Como mencionado anteriormente, as críticas, nos Estados Unidos, contra o plea bargaining têm sido muito importantes entre doutrinadores e têm sido baseadas, pelo menos em certa medida, sobre esta concepção prescritiva do sistema adversarial. Confira e.g. Alschuler, op. cit. nota 114; Alschuler, op. cit. nota 58; John H. Lagbein, Torture and Plea Bargaining, 46 U. CHI.L.REV. 3; Stephen J. Schulhofer, Criminal Justice discretion as Regulatory System, 17 J. LEGAL STUD. 43; Stephen J. Scgulhofer, Is Plea 
presume uma concepção adversarial do processo penal como uma disputa entre duas partes diante de um julgador passivo. Faz sentido que em um modelo de disputa as partes sejam autorizadas a entrar em acordo sobre um plea bargain. Isto é, as partes podem negociar a fim de chegar a um acordo e se as partes acordarem sobre o fim da disputa, o julgador não deveria ter qualquer poder (ou tão somente um poder formal e relativamente menor) de rejeitar esta decisão ${ }^{174}$.

Além disso, as características do modelo de disputa são condições que permitem a possibilidade de desenvolvimento do plea bargaining. Por exemplo, o guilty plea que permite ao acusado colocar um fim na determinação da culpa ou da inocência, concedeu à defesa uma ferramenta negocial em seus acordos com a acusação. Ademais, o fato de que o juiz, como um julgador passivo, normalmente aceita o acordo estabelecido pelas partes (os verdadeiros donos do processo) também oferece um estímulo para o desenvolvimento de tais práticas ${ }^{175}$. Dado o usual respeito do juiz diante do requerimento das partes, o acusado pode estar relativamente certo de que o acordo firmado com o promotor será cumprido, mesmos naquelas situações nas quais o juiz pode não estar

Bargaining Inevitable?, 97 HARV. L. REV. 1037; Stephen J. Schulhofer, Plea Bargaining as Disaster, 101 YALE L.J 1979. Para defesas do plea bargaining nos Estados Unidos Confira, por exemplo, Frank H. Easterbrook, Criminal Procedure as a Market System, 12 J.LEGAL STUD. 289; Frank H. Easterbrook, Plea Bargaining as Compromise, 101 YALE L.J 1969; Robert E. Scott \& William J. Stuntz, Plea Bargaining as Contract, 101 YALE L.J 1909. É importante enfatizar, então, que estas críticas ao plea bargaining e a minha assertiva de que o plea bargaining é uma característica do sistema adversarial estadunidense não são incompatíveis, porque enquanto na maioria destas críticas, o sistema adversarial é considerado um modelo prescritivo, eu concebo-o apenas como uma categoria descritiva. Em outras palavras, seria possível afirmar-se que o plea bargaining é uma característica muito particular do sistema adversarial estadunidense desde uma abordagem descritiva e simultaneamente entender o plea bargaining problemático do ponto de vista normativo ou prescritivo.

174 No sistema federal dos Estados Unidos, o tribunal precisa advertir o acusado sobre a desistência de direitos, voluntariedade do guilty plea e determinar se há uma base fática para ele. Confira genericamente FED.CRIM.P. 11. Contudo, os tribunais normalmente avalizam os acordos celebrados pelas partes.

175 Reciprocamente, uma ampla prática do plea bargaining entre as partes reforça a concepção do juiz como um árbitro passivo. 
limitado aos requerimentos das partes, como em determinados acordos relativos à sentença (sentencing bargains) ${ }^{176}$. Além disso, devido à acusação ter o poder de alterar ou diminuir acusações, a ampla discricionariedade da acusação encontrada no modelo de disputa concede ao promotor ferramentas poderosas e flexíveis para negociar com a defesa sobre um guilty plea ${ }^{177}$.

Reciprocamente, existem poucas práticas que são mais incompatíveis com o sistema inquisitorial e o modelo da investigação oficial do que o plea bargaining. Primeiro, o próprio conceito de guilty plea não existe no sistema inquisitorial ${ }^{178}$. Segundo, não há duas partes que negociam e acordam, como no sistema adversarial, e que poderiam chegar a um consenso não apenas sobre as suas respectivas alegações mas também sobre os fatos do caso. No modelo de investigação oficial, o promotor não é uma parte do processo, mas ao invés, outro oficial, que, como o juiz, deve determinar o que aconteceu ${ }^{179}$. Neste modelo, a verdade "real" deve ser determinada pelo promotor; ela não pode ser negociada nem comprometida. Em qualquer caso o juiz tem a palavra final sobre as conclusões da investigação. Nas negociações e acordos, as partes têm de se reconhecer como iguais ao menos até certo ponto. Porém, no modelo de investigação oficial, o promotor, o juiz e o acusado não são iguais porque este último tem interesses em jogo no processo e os outros não.

Além disso, a maioria das condições necessárias para o potencial desenvolvimento do plea barganing não existe no sistema inquisitorial. Não apenas o conceito de guilty plea não existe naquele sistema, como também a acusação possui uma discricionariedade mais limitada para decidir quais casos e acusações ela deseja movimentar, como simbolizado e regulado

\footnotetext{
176 Confira e.g FED.R. CRIM. P. 11 (c), que inclui duas espécies de recomendações para sentenciamento que o acusador pode fazer: a primeira, não vincula o tribunal enquanto o segundo vincula o tribunal apenas após o aceite do acordo. Para uma proposta que autorize o acusador a configurar uma sentença máxima, Confira Scott \& Stuntz, op. cit. nota 173, na 1953-57.

177 Doutrinadores identificaram esta conexão entre discricionariedade acusatória e plea bargains. Confira e.g, Tracey L. Meares, Rewards for Good Behaviour: Influencing Prosecutorial Discretion and Conduct with Financial Incentives, 64 FORDHAM L. REV.851, 862-73 (1995). 178 Confira LANGBEIN, op. cit nota 42, na 73-74; Moskowitz, op. cit. nota 41, na 1153. ${ }^{179}$ Confira Weigend, op. cit. nota 38, na 1233-34.
} 
pelo princípio da legalidade e da obrigatoriedade da ação pena ${ }^{180}$. Ademais, os juízes normalmente não se sentem limitados àquilo que as partes podem requerer com relação à sentença.

Contudo, apesar desta aparente incompatibilidade entre o plea bargaining e o modelo de investigação oficial, um grande número de países civil law tem, recentemente, demonstrado um interesse em traduzir estes mecanismos para seus processos. As razões variam de uma jurisdição para outra, mas uma razão em comum tem sido o aumento da criminalidade na maioria destes países nos últimos anos ${ }^{181}$. Esta situação produziu uma sobrecarga nos seus processos penais, requerendo deles que tratem de mais casos criminais em menos tempo do que antes ${ }^{182}$. A obtenção do consentimento do acusado, portanto, através de negociações ou do oferecimento de benefícios, poderia tornar os procedimentos penais inquisitoriais regulares desnecessários ou oferecer uma justificativa para simplificar ou expressamente evitá-los. Compreendido este contexto, a introdução de mecanismos de negociação consensual tem sido vista como uma maneira de tornar os rígidos sistemas inquisitoriais mais flexíveis.

A introdução do plea bargaining na Europa Continental e na América Latina é particularmente relevante para a análise da tese da americanização. O próprio fato de que o plea bargaining estadunidense se tornou um importante ponto de referência nas reformas recentes no mundo civil law apoia a versão fraca desta tese. Seria possível pensar, contudo, que a propagação do plea bargaining também apoiaria a versão forte da tese. O plea bargaining estadunidense presume uma concepção

\footnotetext{
${ }^{180}$ Confira op. cit. nota 85.

181 Para uma análise das razões pelas quais as jurisdições continentais europeias traduziram plea bargains para acomodar os seus procedimentos Confira, por exemplo, Françoise Tulkens, Negotiated Justice, in EUROPEAN CRIMINAL PROCEDURES, op. cit. nota 52, na 645-49.

182 Relativamente à Argentina, Confira infra, nota 287. Na França, o projeto que introduziu o "plea bargaining" francês visava aumentar a eficiência do processo penal. Confira Jean Cedras, L'bypothèse de l'américanisation du droit penal français, 45 ARCHIVES DE PHILOSOPHIE DU DROIT, 149, 156 (2001). Relativamente à Alemanha, Confira infra nota 187 e o texto que segue. No que se refere à Itália, Confira, por exemplo, PAOLO FERRUA, La Giustiz̨ia Negoziata nella Crisi della Funz̧ione Cognitiva del Processo Penal, 3 STUDI SUL PROCESSO PENAL, 131, 134 (1997).
} 
adversarial de processo penal. Caso os países civil law traduzissem este mecanismo fielmente e não o rejeitassem mais tarde, o efeito desta importação poderia ser o de que a acusação e a defesa começariam a se pensar como partes em uma disputa e percebidas pelos outros atores jurídicos como tais e algo semelhante se desenvolveria com o juiz como árbitro passivo. Se isto acontecesse, poderiam ser alteradas as disposições internas dos atores jurídicos e produziria uma mudança ou ao menos um sério desafio à subestrutura de significado da investigação oficial pela subestrutura da disputa. Isto produziria, então, uma mudança nas clássicas relações de poder de uma estrutura para outra, assim como mudanças na organização dos recursos material e humano, incluindo as técnicas de gestão processual, entre outros elementos.

Em outras palavras, seria possível pensar o plea bargaining como um cavalo de Troia que pode potencialmente trazer, escondido dentro de si, a lógica do sistema adversarial para o inquisitorial. Se isso ocorresse, então a tese da americanização seria válida até mesmo em sua versão forte porque os sistemas inquisitoriais que traduzissem o plea barganing se tornariam gradualmente "americanizados" pela adoção de uma concepção adversarial de processo penal.

As partes seguintes analisam quatro traduções específicas do plea bargaining que demonstram os complexos efeitos da circulação do plea bargaining entre jurisdições civil law. Estas partes apoiam a noção de que a americanização não está ocorrendo em todas as jurisdições que desenvolveram mecanismos inspirados no plea bargaining nos últimos anos, mesmo se ela estiver ocorrendo em alguns deles. Os quatro exemplos analisados são denominados Absprachen na Alemanha, o patteggiamento na Itália, o procedimiento abreviado na Argentina e a composition na França. Estes quatro mecanismos ou foram rotulados explicitamente de plea bargaining ou foram considerados próximos a ele em cada um destes quatro países e, em alguns casos, nos Estados Unidos ${ }^{183}$.

\footnotetext{
183 Concernente aos Absprachen Confira, por exemplo, Herrmann, Bargaining Justice, infra nota 186; Schünemann, die Absprachen im Strafverfahren, nota 189, na 527. Relativamente ao pattegiamento, Confira, por exemplo, Ferrajoli, op. cit. nota 59. Quanto ao procedimiento abreviado, Confira, por exemplo, Gabriel Ignacio Anitúa, El Juicio Abreviado como una de las Reformas Penales de Inspiración Estadounidense que Posibilitan la Expansión Punitiva, in EL
} 
A análise de cada uma dessas traduções está dividida em duas partes principais. A primeira parte analisa as semelhanças e diferenças entre o plea bargaining estadunidense e os Absprachen, patteggiamento, procedimiento abreviado e composition. A segunda parte analisa os tipos de transformações que estas traduções podem produzir nos processos penais da Alemanha, Itália, Argentina e França. A questão central nesta parte é se estes processos inquisitoriais estão mantendo seu modelo tradicional de investigação, se eles estão se movendo na direção do modelo estadunidense de disputa ou se eles estão se movendo em uma direção diferente destas duas. Este estudo nos permitirá examinar que mudanças estas reformas podem estar produzindo nos processos penais da tradição civil law.

\section{O “PLEA BARGAINING” ALEMÃO.}

Como uma das jurisdições nas quais o modelo de investigação oficial predominou, o sistema alemão não admitia a possibilidade de negociação com o acusado ${ }^{184}$. No final da década de 70 , um dos mais reconhecidos comparativistas estadunidenses se referiu à Alemanha como uma "a terra sem plea bargaining"185. Apesar disto, durante a década de 70, juízes, promotores e advogados de defesa do sistema de justiça criminal alemão começaram a desenvolver negociações ou Absprachen na surdina antes e durante a instrução (trial) ${ }^{186}$. As influências deste desenvolvimento

PROCEDIMIENTO ABREVIADO, op. cit. nota 26, na 137, 144 (Julio B. Maier \& Alberto Bovino eds., 2001). Quanto à composition, Confira, por exemplo, Merle \& Vitu, op. cit. nota 112, na 396.

184 Confira, e.g. Hans-Heiner Kühne, Germany, in CRIMINAL PROCEDURE SYSTEMS IN THE EUROPEAN COMMUNITY 137, 145 (Christine Van Den Wyngaert et al eds., 1993)(“O princípio de "instrução" (Instruktionsmaxime), oposto ao princípio de negociação (Verbandlungsmaxime) impõe sobre todas as autoridades envolvidas nos procedimentos criminais o dever de buscar a verdade". O StPO estabelece o princípio da "instrução" ou princípio inquisitorial. $\iint$ 155. Nr 2, $244 \mathrm{Nr} 2 \mathrm{StPO}$.

${ }^{185}$ Langbein, op. cit. nota 57.

${ }^{186}$ Confira Joachim Herrmann, Bargaining Justice - A Bargain for German Criminal Justice? 53 U. PITT. L. REV.755, 755-57. 
foram o crescente número de processos penais e as dificuldades e duração dos processos penais para crimes econômicos, ambientais e tráfico de drogas ${ }^{187}$. Neste sentido, o instituto parece ter surgido como uma resposta às necessidades práticas ao invés de ser um produto de influências culturais profundas do sistema estadunidense sobre o alemão. A prática permaneceu silenciosa até 1982, quando foi publicado o primeiro artigo sobre o tema, sob um pseudônimo, indicando que esta era uma prática delicada de se discutir pois se chocava contra os princípios básicos do processo penal alemão ${ }^{188}$. Desde então, um vívido debate se iniciou, no qual importantes doutrinadores criticaram e se opuseram à prática enquanto os tribunais geralmente sustentaram-na, apesar de imporem certos limites à ela ${ }^{189}$.

Apesar da forma e conteúdo das negociações e acordos alemães variarem, a ideia básica é a seguinte: durante o procedimento preparatório ou durante o processo, o réu poderia fazer uma oferta para confessar no processo em troca de uma garantia do juiz de que a sentença não excederia certo limite ou de que certo número de acusações seriam retiradas pelo promotor $^{190}$. Estas negociações poderiam ser iniciadas pela defesa, pelo

187 Confira ROXIN, op. cit nota 69, $\int 15$, na 95; Frase \& Weingend, op. cit. nota 114, na 345, n. 195.

${ }^{188}$ Detlef Deal, Der strafprozessuale Vergleich, 2 STRAVERTEIDIGER 545 (1982).

189 Para uma análise em inglês do debate, Confira Thomas Swanson, The German "Plea Bargaining” Debate, 7 PACE INT'L L. REV. 372 (1995). Um dos maiores críticos destas práticas tem sido o Prof. Bernd Schünemann. Confira e.g. Bernd Schünemann, Absprachen im Strafverfabren? Grundlagen, Gegenstände und Grenzen, in VERHANDLUNGEN DES ACHTTUNDFÜNFZIGSTEN DEUTSCHEN JURISTENTAGES L6 (Ständige Deputation des deustchen Juristentages ed. 1990). Os acordos não foram formalmente introduzidos no Código de Processo Penal Alemão. Confira e.g. Thomas Weigend, Abgesprochene Gerechtigkeit - Efficien₹ durch Kooperation im Strafverfabren?, 45 JURISTENZEITUNG (J.Z) 774, 775, (1990) (afirmando que o Código de Processo Penal da Alemanha não menciona os acordos). Nota do tradutor: anos depois da publicação deste artigo, os acordos foram formalmente introduzidos no Código de Processo Penal Alemão \$257c.

190 Neste artigo, eu analisarei apenas os tipos de acordos que geraram a maior controvérsia no sistema de justiça criminal alemão. Há outros dois mecanismos que também têm sido comparados ao plea bargaining estadunidense. $\mathrm{O}$ primeiro é o procedimento de ordem penal - Strafbefehlsverfahren - regulamentado nas seções 407-12 do 
juiz ou pela acusação. Nem todos os atores deveriam participar da negociação, podendo ser realizada apenas entre o juiz e a defesa ${ }^{191}$. No entanto, todos os atores processuais devem ser informados de quaisquer negociações ${ }^{192}$. Além disso, os acordos requerem cooperação e confiança mútua entre o juiz, a acusação e a defesa ${ }^{193}$.

Como se pode ver nesta descrição, as transformações sofridas pelo plea bargaining estadunidense, ao ser traduzido para o processo penal alemão, são consideráveis ${ }^{194}$. Primeiro, os acordos alemães ou Absprachen não tratam de guilty pleas e sim de confissões. Desta forma, tornando mais fácil provar os fatos imputados através da confissão, o acordo normalmente encurta o processo embora não o substitua ${ }^{195}$. Segundo, uma

StPO. Neste procedimento o acusador, ao invés de encaminhar o processo para o julgamento requer ao juiz uma ordem penal. O promotor prepara um projeto de ordem penal que descreve em detalhes o caso e requer uma consequência jurídica específica que pode incluir uma multa, a suspensão do direito de dirigir ou mesmo uma detenção de até 1 ano executada no regime de livramento condicional. Se o projeto de ordem penal é homologado pelo juiz, é encaminhado ao acusado que deve se opor a ele, a fim de evitar a sua execução. Este procedimento é geralmente utilizado para gerir a massa de contravenções. Para uma descrição disso em inglês, Confira Herrmann, op. cit. nota 186, na 760-63. Este procedimento tem sido comparado ao plea bargaining porque o promotor e a defesa podem negociar sobre as consequências da ordem penal. Confira e.g. Frase \& Weigend, op. cit. nota 114, na 345 . O segundo procedimento que foi comparado ao plea bargain é aquele estabelecido no $\ 153$ (a) do StPO. Em um caso envolvendo um crime de menor gravidade, com os consentimentos do tribunal e do acusado, este procedimento autoriza a acusação pública a dispensar as acusações e concorrentemente, a impor uma condição sobre o acusado. Esta condição pode incluir a reparação do dano ocasionado pelo crime, a prestação de serviço comunitário, etc. neste sentido, é similar à prática estadunidense da diversion. Este procedimento foi adicionado ao Código de Processo Penal da Alemanha em 1975, Confira Herrmann, op. cit. nota 186, na 757. Para uma análise deste mecanismo em língua inglesa, Confira id.

191 Confira e.g. Swenson. op. cit. nota 189, na 378-79.

192 Entscheidungen des Bundesgerichtshofes in Strafsachen (BGHSt) 43, 195 (195, 20506).

${ }^{193}$ Confira e.g. Swenson op. cit. nota 189, na 378.

Confira Herrmann, op. cit. nota 186, na 764.

${ }^{194} \mathrm{O}$ plea bargaining estadunidense tem sido um modelo de referência e um fator que fomentou o desenvolvimento destas práticas de acordo. Confira Weigend, op. cit. nota 189.

${ }^{195}$ Confira Herrmann, op. cit. nota 186, na 764. 
vez que a defesa tem pleno acesso ao dossiê escrito que contém a investigação preliminar - há plena revelação das provas produzidas nesta fase da acusação para a defesa no sistema alemão - a defesa tem melhor conhecimento do caso do que no sistema estadunidense durante as negociações ${ }^{196}$. Terceiro, o juiz presidente da instrução é normalmente um participante ativo nestes acordos e negociações. Na Alemanha os dois principais atores nas negociações não são normalmente a acusação e a defesa como no modelo estadunidense, mas sim o juiz da instrução (presiding trial judge) e a defesa ${ }^{197}$.

Estas diferenças substanciais entre o plea bargaining estadunidense e o Absprache alemão revelam a inadequação da "metáfora do transplante legal" para compreender estes fenômenos das influências jurídicas. É equivocado afirmar que o plea bargaining estadunidense foi transplantado para a Alemanha porque esta afirmação transmite a falsa noção de que o mesmo mecanismo jurídico existe em ambos os países. Reciprocamente, a metáfora da tradução leva em consideração a possibilidade de que diferenças substanciais podem ser desenvolvidas entre a prática jurídica original e a traduzida. Através da metáfora da tradução, as diferenças entre os "plea bargains" estadunidense e alemão podem ser explicadas pelas transformações que este mecanismo sofreu ao ser traduzido de um sistema com uma predominante estrutura de interpretação e significado adversarial para um sistema no qual a estrutura de significado inquisitorial predomina. Os tradutores alemães do "plea bargaining" introduziram a prática silenciosamente, conscientes de que sua legitimidade e significado dentro da estrutura de interpretação inquisitorial alemã era questionável. Deste modo, por exemplo, eles não tinham poderes para mudar oficialmente outros aspectos do processo penal alemão através de uma reforma do Código de Processo Penal da Alemanha. Estas restrições limitaram o

\footnotetext{
${ }^{196}$ Id. A Suprema Corte dos Estados Unidos tem sustentado que a acusação não tem um dever constitucional de revelar impedimentos ou provas de defesa antes que um guilty plea seja acordado. Confira United States v. Ruiz, 536, U.S 622 (2002). Para uma análise dos problemas que a descoberta (discovery) limitada apresenta ao plea bargain nos Estados Unidos Confira, por exemplo, Eleanor Ostrow, The Case for Preplea Disclosure, 90 YALE L.J. 1581 (1981).

197 Confira Herrmann, op. cit. nota 186, na 764.
} 
alcance do poder de tomar decisões e extinguiram a possibilidade de fidelidade ao modelo de plea bargaining estadunidense ao traduzirem a nova prática.

Este poder limitado significou que os tradutores tiveram que negociar substancialmente com a estrutura de interpretação e significado inquisitorial pré-existente, disposições internas predominantes entre os atores jurídicos alemães e a estrutura de poderes processuais. Por exemplo, o processo penal alemão não incluiu o conceito de guilty plea e não havia reforma legal que poderia introduzir este conceito. Portanto, os tradutores tiveram que tratar a admissão de culpa negociada não como um guilty plea mas como uma confissão. Isto significa que os processos ainda teriam que ocorrer, mesmo que eles pudessem ser encurtados através dos Absprachen. Além disso, na estrutura de interpretação e significado inquisitorial, o juiz é um jogador ativo e o mais poderoso do processo ${ }^{198}$. Consequentemente, quaisquer acordos eficazes para concluir processos de uma forma rápida devem incluí-lo, e na prática, o juiz desempenha um papel central nas negociações; apenas o juiz pode assegurar ao acusado que a sentença respeitará certo limite, e apenas o juiz tem o controle sobre o poder do acusador de descartar acusações na fase de instrução (trial phase). Desse modo, a tradução do plea bargaining para as práticas alemãs teve que ser adaptada à distribuição preexistente de poderes processuais, na qual o juiz aparece como a figura mais importante do processo.

Os próximos pontos para explorar são os tipos de transformações que estas práticas podem produzir no processo penal alemão no futuro. $\mathrm{O}$ plea bargaining estadunidense tem o potencial de transformar a estrutura de interpretação e significado, as disposições internas de seus atores jurídicos e a distribuição de poderes processuais entre eles na Alemanha. Neste caso, no entanto, o Absprache alemão não se parece com um cavalo de Troia do modelo de disputa estadunidense. $\mathrm{O}$ juiz alemão ainda é o jogador mais ativo no processo e não se tornou um árbitro passivo. Com isso, mesmo que a ampla adoção desta prática afete o modo como os juízes alemães percebam seus papeis e sejam percebidos pelos outros

${ }^{198}$ Confira e.g. ROXIN, op. cit. nota 69, \15, na 95. 
atores jurídicos, o resultado final ainda não será o de um julgador passivo $^{199}$.

Contudo, seria ainda o juiz um investigador oficial da verdade se esta prática impusesse sua lógica sobre resto do sistema de justiça criminal alemão? Em outras palavras, pode o modelo de investigação oficial absorver e sobreviver a esta tradução ou ele será radicalmente transformado por ela? Qualquer um dos dois cenários é possível.

O modelo da investigação oficial pode absorver acordos de confissão, desde que a maioria dos atores jurídicos compreenda e use os acordos como uma ferramenta para descobrir a verdade e não como um mecanismo de finalização rápida de casos criminais ${ }^{200}$. Na verdade, a oferta de benefícios ao acusado em troca de uma confissão detalhada, que serviria como uma circunstância atenuante para fins de sentenciamento, não é propriamente nova dentro do modelo de investigação oficial. Com isso, acordos de confissão poderiam ser interpretados como uma extensão desta prática.

199 Apesar de não existirem dados oficiais sobre como esta prática é amplamente empregada, de acordo com Weigend, várias estimativas e surveys indicam que um acordo em cada quatro processos ocorre. Weigend, op. cit. nota 194, na 774. Isto indica que juízes, acusadores e advogados de defesa têm amplamente aceito esta nova prática. $\mathrm{O}$ estímulo que as novas práticas originam nos juízes, promotores e advogados de defesa i.e, a redução do número de processos e a aceleração da disposição de processos parecer ser a principal razão para a sua muito difundida aceitação. Para uma análise destes estímulos, Confira Bernd Schünemann, Die Absprachen im Strafverfahren, in FESTSCHRIFT FÜR PETER RIESS 525, 533-34 (Ernst Hanack et al. eds., 2002).

$200 \mathrm{O}$ sistema da investigação oficial poderia também sobreviver se as práticas de acordo fossem censuradas - i.e através de uma proibição jurídica. Mesmo que alguns acadêmicos tivessem sugerido a possibilidade, a discussão entre juízes, acusadores e advogados de defesa se concentrou não na eliminação das práticas de acordo, mas em como as práticas traduzidas deveriam ser interpretadas. A explicação para esta limitação da discussão parece ter se enraizado nos estímulos que juízes, promotores e advogados de defesa para aceitar estas práticas de acordo. Indiscutivelmente por que professores de direito não estão submetidos ao mesmo sistema de estímulos, eles têm sido mais fieis às suas disposições internas inquisitoriais preexistentes que os práticos. Sobre a profunda divisão entre a posição da maioria dos professores de direito e os práticos relativamente aos acordos, Confira, por exemplo, Thomas Weigend, Eine Prozessordnung für abgesprochene Urteile?, 19 NEUE ZEITSCHRIFT FÜR STRAFRECHT (NStZ) 57 (1999). 
Duas importantes decisões judiciais oferecem indicações de que um número significativo de atores jurídicos no sistema de justiça criminal alemão está tentando interpretar e dirigir os acordos de confissão nesta direção. Primeiro, o Tribunal Constitucional Federal (BverfG), em sua única decisão sobre a matéria ${ }^{201}$, declarou que estes acordos são admissíveis contanto que não violem a noção constitucional de Rechtsstaat - Estado de direito - e um número considerável de princípios processuais $^{202}$. Entre estes princípios, o BverfG mencionou o princípio do dever do juiz e da acusação de investigar a verdade real ${ }^{203}$. Dessa forma, devido ao seu dever de investigar a verdade, o juiz não poderia condenar um acusado baseado num acordo de confissão caso ele se considerasse obrigado a colher mais provas ${ }^{204}$.

Ademais, o Tribunal de Justiça Federal Alemão, em sua decisão de 28 de agosto de 1997, analisou detalhadamente, pela primeira vez, os requisitos que estes acordos devem obedecer a fim de serem admissíveis ${ }^{205}$. Entre estes requisitos não deve haver violação ao dever judicial de buscar a verdade $^{206}$. Isso significa, por exemplo, que o tribunal não pode fundamentar sua decisão apenas em uma confissão obtida através de um acordo; o tribunal deve examinar a credibilidade de tal confissão e, eventualmente, ordenar a produção de novas provas no processo ${ }^{207}$.

201 Bundesverfassungsgericht (BverfGE) (Julgamento de Jan. 28, 1987), citado in Volker Gallandi, Absprachen im Strafprozess, 1987, NStZ 419, 419.

202 Confira Id., na 419 (discutindo os princípios de culpabilidade ou mens rea (das Schuldprinzip) e igualdade ou proteção igual (der Gleichheitssatz) como restrições aos Absprachen).

203 Id. O princípio de investigação (der Ermittlungsgrundsatz), também chamado de princípio da verdade real ou inquisitorial, significa que o juiz deve proceder à sua própria investigação sobre o caso. Este princípio é estabelecido no Código de Processo Penal Alemão (StPO) nas seções 155 Nr 2 e 244 Nr 2. Confira ROXIN, op. cit. nota 69, \ 15 na 95.

204 BverfGE (Julgamento de 27 de Jan. de 1987), citado em Volker Gallandi, 1987 Absprachen im Strafprozess 419, 419.

205 BGHSt 43, 195.

206 Id. na 204.

207 Id. Para uma análise desta decisão e dos requisitos remanescentes impostos aos acordos, Confira ROXIN, op. cit. nota 69, \15, na 96-97. 
É razoável dizer, então, que estas duas decisões concebem a confissão obtida como algo diferente do guilty plea. $\mathrm{O}$ acordo de confissão não pode ser apenas uma justificativa processual para concluir um processo penal. Ele deve fornecer elementos de prova e ter credibilidade suficiente para embasar uma condenação criminal. Caso contrário, o tribunal deve produzir novos elementos de provas no processo.

Porém, há uma segunda tendência dentro do processo penal alemão em interpretar essas confissões negociadas como equivalentes ao guilty plea $^{208}$. Um exemplo desta tendência é a decisão de 10 de junho 1998, prolatada por outra turma do Tribunal de Justiça Federal Alemão ${ }^{209}$. Neste caso, depois de ler a acusação no início do julgamento, o tribunal inquiriu o acusado sobre a correição da acusação, pergunta a qual ele respondeu positivamente. Baseado apenas nesta simples aceitação da imputação, o tribunal condenou o acusado e condenou-o a 8 anos de prisão. A segunda câmara do BGHSt manteve a decisão ${ }^{210}$.

A interpretação sobre o que constitui esta confissão negociada está no centro de uma discussão entre duas diferentes concepções de processo penal. De acordo com a primeira concepção, que tem sido predominante na Alemanha por um longo tempo, o processo penal é uma investigação conduzida pelo juiz e acusador para determinar a verdade. Neste contexto, a confissão negociada pode ser adaptada a esta estrutura processual de interpretação e significado, se ela for interpretada e usada como uma ferramenta para descobrir a verdade.

De acordo com a segunda concepção, o processo penal é apenas uma "linha de montagem" que deve resolver casos criminais o mais rápido possível $^{211}$. É importante lembrar, então, que o principal gestor da "linha

208 Isto demonstra como a tradução dos bargains ao processo penal alemão pode eventualmente, transformar o sentido de alguns conceitos jurídicos como o de confissão, se não o próprio modelo de investigação oficial como um todo.

${ }^{209}$ Bundesgerichtshof (BGH) (Julgamento de 10 de jun. 1998), citado em Angabe Grundes für den Ausschluss der Öffentlichkeit.

210 Id. na 93.

211 A referência, é claro, é a famosa categoria "modelo de controle criminal" de Herbert Packer, que concebe o processo penal como uma "linha de montagem" e é oposta à categoria do "modelo de devido processo", concebida como uma "pista de obstáculos". Confira PACKER, op. cit. nota 26. Contudo, como explicarei, este modelo alemão difere 
de montagem" no plea bargaining alemão, não é o acusador, como no modelo de disputa estadunidense, mas o juiz da instrução (trial judge $)^{212}$. Além disso, apesar de o juiz ser o principal gestor, ela ainda necessita da colaboração da defesa e da acusação porque a resolução do caso é apenas possível através da sua participação. Isto significa que se esta tendência prevalecesse na Alemanha, a sua estrutura de interpretação e significado predominante não seria nem o modelo de investigação oficial nem o modelo de disputa. Seria alguma coisa diferente, que eu chamarei provisoriamente de "modelo do juiz-gestor baseado na cooperação" 213 .

Neste sistema do juiz-gestor, o papel do juiz não é nem o de um árbitro passivo entre as partes nem o de um investigador ativo. Ao invés, é o de assegurar que os casos criminais sejam processados tão rapidamente quanto possível. O juiz, usando seu poder mais amplo, sutilmente (ou nem tão sutilmente) pressiona a acusação e a defesa para colaborar para uma rápida conclusão do processo ${ }^{214}$. A acusação é concebida como um

do modelo de controle do crime de Packer, mesmo que eles compartilhem do objetivo de descartar processos rapidamente.

${ }^{212}$ Este papel ativo do juiz distingue esta tendência do processo penal alemão do modelo de controle criminal de Packer. O modelo de controle criminal pressupõe a existência de um sistema adversarial, Confira Id. na 157, e desse modo, de um juiz relativamente passivo. Mas uma vez que o juiz é ativo no modelo alemão, este modelo difere daquele de Packer.

$213 \mathrm{O}$ modelo do juiz-gestor baseada na coordenação apresenta semelhanças à tendência no processo civil estadunidense do juiz sendo um gestor ativo da controvérsia ao invés de um árbitro imparcial como no sistema adversarial. Entre os artigos seminais que descrevem algumas destas mudanças no processo civil dos Estados Unidos Confira, por exemplo, Abram Chayes, The Role of the Judge in Public Law Litigation, 89, HARV.L.REV. 1281 (1976); Owen M. Fiss, Foreword: The Forms of Justice, 93, HARV.L.REV. 1 (1979); e Judith Resnik, Managerial Judges, 96 HARV.L.REV. 374 (1982). Para uma análise que desafia a visão de que estes desenvolvimentos são inteiramente novos para o processo civil estadunidense Confira Theodore Eisenberg \& Stephen C. Yeazell, The Ordinary and the Extraordinary in Institutional Litigation, 93 HARV.L.REV. 465 (1980). Para uma análise que questiona se estes desenvolvimentos descrevem adequadamente o processo civil dos Estados Unidos nos casos complexos Confira William B. Rubinstein, A Transactional Model of Adjudication, 89 GEO.L.J. 371 (2001).

214 Apesar da maioria dos plea bargains dos Estados Unidos ocorrer através de negociações conduzidas exclusivamente pela acusação e defesa há juízes que, em certos casos, encorajam as partes para chegar a um acordo a fim de evitar o julgamento. Neste sentido, 
colaborador do juiz que também contribui para o rápido processamento de casos criminais. $\mathrm{O}$ advogado de defesa é tanto um agente do acusado que deve obter o melhor resultado para seu cliente, como um ator jurídico profissional que tem o dever de colaborar com os outros atores jurídicos profissionais na rápida resolução dos $\operatorname{casos}^{215}$.

Isto não quer dizer, contudo, que a verdade não desempenha nenhum papel neste modelo. Como nos modelos de disputa e de investigação oficial, ninguém quer condenar uma pessoa inocente ou absolver uma culpada. Contudo, encontrar a verdade é um objetivo ao menos tão importante quanto a conclusão rápida do caso, e o processo não é estruturado como uma investigação ${ }^{216}$.

A importância atual do sistema do juiz-gestor baseado na colaboração, no processo penal alemão, coloca uma questão empírica que

o sistema do juiz-gestor baseado na cooperação pode inclusive ter alguma presença nos Estados Unidos. Contudo, esta prática é relativamente secundária nos plea bargains estadunidenses, ao menos no sistema de justiça criminal habitual, e o sistema de disputa é ainda predominante neste país. Estas espécies de práticas são mais comuns nos processo civis dos Estados Unidos. Confira e.g. Resnik, op. cit. nota 213.

215 Sobre a redefinição do papel do advogado de defesa nos acordos na Alemanha Confira Weigend, op. cit. nota 194, na 779.

216 A concepção de verdade no modelo de juiz-gestor baseada na cooperação é mais relativa e consensual do que no sistema inquisitorial. Se o promotor, a defesa e o tribunal concordam que os fatos aconteceram de certa forma - i.e através de confissões consentidas - como eles se sucederam se torna menos relevante. Neste sentido, a concepção de verdade neste modelo representa semelhanças à concepção de verdade do sistema adversarial. Portanto, mesmo se a tradução das confissões consentidas não está empurrando as práticas alemãs na direção do modelo de disputa, os Absprachen tem o potencial de introduzir uma concepção de verdade mais próxima daquela do sistema adversarial. Se este potencial for cumprido, o resultado seria a americanização do sistema alemão no que se refere à concepção de verdade, mesmo que não houvesse americanização concernente ao modelo de disputa. Isto mostra como a americanização não é um jogo de tudo ou nada. A introdução do Absprache alemã poderia eventualmente criar novas divergências no modelo estadunidense de disputa por conta do avanço do modelo de juiz-gestor baseado na cooperação e, ao mesmo tempo, por causa da convergência com o sistema adversarial estadunidense em uma concepção mais relativa e consensual de verdade. 
vai além do escopo deste artigo ${ }^{217}$. Os pontos que precisam ser enfatizados aqui são de que já há indícios de que este sistema tem certa presença, ao menos de forma incipiente, no processo penal contemporâneo alemão e de que este sistema é diferente tanto do modelo de disputa quanto do modelo de investigação oficial. E também, até certo ponto, ele parece ter se desenvolvido como uma consequência da tradução dos acordos negociados no país nos anos 70, e como uma consequência das negociações que os tradutores jurídicos tiveram de fazer com a estrutura de interpretação e significado inquisitorial preexistente, disposições internas predominantes entre os atores jurídicos e a distribuição de poderes processuais.

Em suma, nos anos 70 o sistema inquisitorial, com o seu modelo de investigação oficial, era a estrutura de interpretação e significado predominante na Alemanha e a maioria dos atores incorporou esta estrutura em suas disposições internas. Devido a mudanças sociais externas que aumentaram o número e a complexidade dos processos penais, os atores jurídicos alemães receberam fortes estímulos para mudar suas atitudes em relação às negociações e acordos com o acusado. Apesar disso, o plea bargaining sofreu uma profunda transformação quando foi traduzido da estrutura de significado adversarial para um quadro inquisitorial devido à estrutura de interpretação e significado inquisitorial preexistente, disposições individuais predominantes e estrutura de poderes processuais, que neutralizaram, até certo ponto, seu efeito potencial de americanização ou "adversarialização" no processo penal alemão.

Entretanto, este novo mecanismo apresentou um desafio à estrutura de significado inquisitorial predominante baseada no modelo de investigação oficial. A seriedade deste desafio é uma questão que ainda deve ser determinada através de estudos empíricos. Contudo, desde a introdução dos Absprachen, tem havido uma batalha entre o modelo de investigação oficial para adaptar o novo mecanismo à sua própria lógica e o modelo do juiz-gestor baseado na cooperação para interpretar este mecanismo em outra direção. Esta luta deveria ser entendida não apenas

217 Eu deixo para um trabalho futuro uma análise mais detalhada do modelo de juizgestor baseado na cooperação, assim como a questão de verificar se estaria se desenvolvendo em outras jurisdições além da Alemanha. 
em termos abstratos como o confronto entre duas estruturas de interpretação e significado. Deveria ser compreendida como uma luta entre atores jurídicos com disposições internas que correspondem a estas estruturas de significado ${ }^{218}$. As interações entre estas duas estruturas de significado - e outras estruturas que estão presentes no processo criminal alemão e na sociedade - podem ainda impactar outros aspectos das práticas da justiça criminal alemã, tais como a organização dos recursos humanos e materiais, ética jurídica etc. Uma análise destas mudanças deveria ser incluída em um estudo mais amplo sobre as transformações produzidas pela tradução do plea bargaining na Alemanha.

Sob a perspectiva do debate da tese da americanização, o exemplo alemão mostra que, devido à transformação que sofreu em sua tradução e as interações que se seguiram, o Absprache alemão não americanizou o processo penal alemão, na medida em que não introduziu uma concepção cultural de processo penal como uma disputa entre a acusação e a defesa diante de um juiz passivo. Na realidade, devido à sua tradução jurídica, este processo pode estar numa encruzilhada entre seu tradicional modelo inquisitorial de processo penal e um modelo que não se mostra nem adversarial nem inquisitorial.

\section{O “PLEA BARGAINING” ITALIANO}

Comparado com o Absprache alemão, o plea bargaining, ou patteggiamento, foi mais fiel ao modelo estadunidense, mesmo que apresente diferenças substanciais da prática estadunidense. Os tradutores jurídicos italianos tiveram muito mais poder para proceder à reforma do que os tradutores alemães e foram capazes de introduzir o plea bargaining italiano como parte de reformas processuais penais mais profundas e amplas, inspiradas no sistema adversarial estadunidense. Com isso, os reformadores italianos tiveram que ceder muito menos do que os alemães e tiveram muito mais poder para alterar a estrutura inquisitorial de

218 A luta pode ocorrer não apenas entre atores jurídicos individuais mas também nos atores jurídicos individuais que possuem uma ambivalência interna sobre ambos os sistemas. 
significado, distribuição de poderes processuais, etc. Tendo em vista que estas reformas de caráter adversarial possuíam considerável apoio político, eles puderam aproximar o sistema italiano do sistema adversarial estadunidense muito mais do que qualquer outra jurisdição civil law. Contudo, mesmo no atual sistema italiano, muitos atores jurídicos são ainda movidos por uma série de predisposições internas de cunho inquisitorial. Além disso, as estruturas inquisitoriais de interpretação e significado e poderes processuais ainda permanece.

Em 1989 a Itália adotou um novo código de processo penal que substituiu o Código Rocco, promulgado no regime de Mussolini ${ }^{219}$. Este novo código representou a tentativa mais séria de transferir procedimentos criminais adversariais para uma jurisdição inquisitorial desde 1791, quando os franceses tentaram importar o sistema inglês no calor da Revolução ${ }^{220}$. A reforma italiana foi justificada tanto nos fundamentos do devido processo quanto nos da eficiência, mas tinha uma predominante inspiração no due process $^{221}$. O processo penal estadunidense foi o principal modelo para estas reformas adversariais devido ao prestígio que o sistema jurídico estadunidense em geral, e o processo penal em particular gozavam entre um número considerável de atores jurídicos desde o fim da Segunda Guerra Mundial ${ }^{222}$.

As reformas adversariais podem ser descritas e analisadas utilizando os dois pares de modelos desenvolvidos na Parte III: o modelo coordenado versus o modelo hierárquico e o modelo de disputa versus o modelo da investigação oficial ${ }^{223}$.

Com relação ao primeiro par, os reformadores tentaram importar a técnica de gerenciamento oral do modelo coordenado, reduzindo a

\footnotetext{
219 Neste sentido, a introdução do código poderia ser analisada como parte de uma transição para a democracia que começou na Itália após a Segunda Guerra Mundial.

${ }^{220}$ A clássica descrição desta importação é a de ESMEIN, op. cit. nota 66, na 399-480.

${ }^{221}$ Confira Vassalli, op. cit. nota 118.

222 Confira Grande, op cit. nota 35, na 230-32.

${ }^{223}$ Para análises na língua inglesa destas reformas Confira Amodio \& Selvaggi, op. cit. nota 118; Stephen P. Freccero, An Introduction to the New Italian Criminal Procedure, 21 AM. J. CRIM. L. 345, (1994); William T. Pizzi \& Luca Marafioti, The New Italian Code of Criminal Procedure: the Definition of Building an Adversary Trial System on a Civil Law Foundation, 17 YALE J. INT'L. L. 1 (1992).
} 
importância das provas colhidas na fase de investigação preliminar através do dossiê inquisitorial escrito ${ }^{224}$. Eles fizeram isso exigindo a preparação de um dossiê escrito especial para a instrução, de forma que o julgador competente não tivesse conhecimento dos depoimentos colhidos na fase de investigação preliminar ${ }^{225}$, assim como introduzindo regras probatórias como a "hearsay evidence rule" que impedia os testemunhos extraprocessuais de serem admitidos no julgamento, exceto para os casos de impedimento (impeachment) ${ }^{226}$.

Com relação ao segundo par, os reformadores jurídicos italianos introduziram inúmeras reformas para promover o modelo de disputa no sistema italiano. Primeiro, as partes devem agora desenvolver procedimentos investigatórios, tanto na fase da investigação preliminar quanto na processual. Isto eliminou o juiz investigador (gindice istruttore) como responsável pela investigação preliminar ${ }^{227}$, substituindo-o pelo promotor e pelo advogado de defesa, que podem conduzir as suas próprias investigações ${ }^{228}$. Também foi alterada a organização do julgamento que passou a ser dividido em um caso para a acusação e outro para a defesa ${ }^{229}$, além de introduzir o exame direto e o cruzado como formas de interrogar as testemunhas no julgamento ${ }^{230}$. Além destas e de

${ }^{224}$ Confira e.g. Amodio \& Selvaggi, op. cit. nota 118, na 1217.

225 Art. 439 do C.P.P.I

226 Arts. 500, 503 do C.P.P.I. A reação inquisitorial contra estas ideias - combinada com uma delicada situação política na qual dois dos principais juízes anti-máfia foram assassinados - veio à tona após alguns anos mais tarde quando a Corte Constitucional da Itália, em suas decisões 254/1992 e 255/1992 declarou inconstitucionais os artigos 513.2, 500.3 e 500.4. Decisão 255/1992, op. cit. nota 166; Corte cost. 18 mag. 1992. n.254, 103 Racc. Uff. Cort. Cost. 1992, 809. Todavia, em 1999, o Parlamento Italiano introduziu um novo artigo 111 à Constituição da Itália, voltando à direção original das reformas de 1989 rumo ao incremento do papel das técnicas orais de gestão de processo do sistema coordenado.

${ }^{227}$ Confira Vassali, op. cit. nota 118 , na 07.

${ }^{228}$ No que se refere ao poder da acusação realizar investigações preliminares, Confira Art. 358 do C.P.P.I. Os poderes investigatórios da defesa foram incluídos pela Lei 271/1989, supra, nota 167, e depois incorporados no Código de Processo Penal, artigos 391-bis-decies pela Lei 397/2000, supra, nota 167.

${ }^{229}$ Art. 496.1 do C.P.P.I.

230 Art. 498 do C.P.P.I. 
outras reformas, o código italiano incluiu uma regra que estabelece que o juiz só pode determinar a produção de provas requeridas pelas partes; e somente em circunstancias excepcionais o juiz pode atuar sua sponte $e^{231}$.

Segundo, a reforma introduziu uma série de mecanismos simplificadores e consensuais através dos quais a acusação e a defesa podem negociar e concordar em evitar os procedimentos regulares ${ }^{232}$. A introdução destes mecanismos simplificadores foi justificada com base na eficiência ${ }^{233}$. Contudo, eles também fazem parte de uma reforma mais ampla do processo penal italiano, na qual as influências culturais do modelo estadunidense - como um sistema que simboliza valores democráticos e a eficiência ao lidar com o crime - desempenhou um papel importante. Estes mecanismos incluíram a applicazione della pena sulla rechiesta delle parti - aplicação da pena por requerimento das partes ${ }^{234}$ - que é normalmente chamada de plea bargaining italiano, ou simplesmente patteggiamento, que significa barganha em italiano ${ }^{235}$.

231 Arts. 190, 493,1, 495.1 e 507 do C.P.P.I.

232 Arts. 438-64 do C.P.P.I.

${ }^{233}$ Confira, e.g., Vassalli, supra nota 118, na 07.

234 Uma precursora desta instituição foi a applicąione di sanzioni sostitutive su richista dell'imputato introduzida em 1981 pelo L.vo 24 nov. 1981, n.689, Racc. Uff. 1981, vol.13, 3657, publicado in Gazz. Uff., 30 nov. 1981, n.329. O objetivo deste mecanismo era muito limitado, por que ele se aplicava apenas aos crimes punidos com até 3 meses de prisão. Confira e.g. Pizzi \& Marafioti, op. cit. nota 223, na 22.

235 Além do pattegiamento, a reforma de 1989 introduziu dois outros mecanismos que podem ser comparados ao plea bargaining por que incluíram negociações potenciais entre acusação e defesa e que requeriam o consentimento do acusado pera serem aplicados. $\mathrm{O}$ primeiro foi o procedimento per decreto. Arts. 449-64 do C.P.P.I. (semelhante à ordem penal alemã analisada por Herrmann, Bargaining Justice, op. cit. nota 186). O segundo é o giudizizo abbreviato, arts. 438-43 do C.P.P.I. (no qual o acusado renuncia ao direito ao julgamento e aceita ser julgado na audiência preliminar). Em troca, ele recebe uma redução de um terço da sentença normal. Este mecanismo inicialmente requeria o consentimento da acusação para a sua aplicação, e desse modo abriu a porta para negociações entre acusação e defesa. Contudo, desde então, primeiro os tribunais e depois o Parlamento limitaram o consentimento da acusação como um requisito para a sua aplicação. Para uma análise deste procedimento Confira Elena Maria Catalano, Il Giudizio Abbreviato, in GIUDICE UNICO E GARANZIE DEFENSIVE, 118 (Ennio Amodio \& Novella Galantini eds., 2000). Por uma questão de espaço eu não vou analisar estes dois mecanismos no texto principal mas eles deveriam ser incluídos em um trabalho mais amplo. 
Uma diferença crucial entre a introdução do Absprache na Alemanha e do patteggiamento na Itália é de que o segundo foi introduzido por lei e como parte de uma reforma que tinha considerável apoio político. Neste sentido, os tradutores ${ }^{236}$ tiveram maior liberdade para decidir o alcance de sua fidelidade ao plea bargaining estadunidense. Além disso, os reformadores italianos possuíam um conhecimento mais profundo do sistema de justiça estadunidense ${ }^{237}$, permitindo-lhes desenhar um mecanismo muito mais parecido com o plea bargaining estadunidense do que o Absprache alemão, mas ainda levando em conta a estrutura de significados, disposições internas e divisões de poderes do sistema inquisitorial preexistente.

No patteggiamento, a defesa e a acusação podem chegar a um acordo sobre a sentença e requerer que ela seja imposta pelo juiz ${ }^{238}$. Mediante este acordo, a sentença regular pode ser reduzida em até um terço se a pena

236 O Código de Processo Penal Italiano foi elaborado por uma comissão designada pelo decreto ministerial de 03 de março de 1987, e foi composta por nove professores: Giandomenico Pisapia (Presidente), Defino Siracusano (Vice-Presidente), Ennio Amodio, Vincenzo Cavallari, Mario Chiavario, Oreste Dominioni, Vittorio Grevi, Guido Neppi Modona e Mario Pisani; oito juízes: Giancarlo Caselli, Enrico Di Nicola, Liliana Ferraro, Giuseppe La Greca, Giorio Lattanzi, Ernesto Luppo, Vittorio Mele e Piero Luigi Vigna; e um advogado: Giusepe Frigo. Confira Vassalli, op. cit. nota 118, na 03.

${ }^{237}$ Por exemplo, o Professor Enio Amodio foi um membro da Comissão Ministerial que designou as reformas e, ao mesmo tempo, um comparatista sofisticado. Confira e.g. Ennio Amodio, Il Modello Accusatorio Statunidense e il Nuovo Processo Penale Italiano: Miti e Realtà della Giustizia Americana, in IL PROCESSO PENALE NEGLI STATI UNITI D'AMERICA VII (Ennio Amodio \& M. Cherif Bassiouni eds., 1988).

${ }^{238} \mathrm{O}$ pattegiamento é regulado nos arts. 444-48 do Código de Processo Penal Italiano. Para uma análise detalhada destes artigos Confira FRANCO CORDERO, PROCEDURA PENALE, 960-73 (5th ed 2000). (Professor Cordero, contudo, não inclui em sua análise as reformas introduzidas pela Lei 134/2003, que eu analiso infra, nota 239). No código original, as partes poderiam requerer a aplicação do mecanismo até a abertura do julgamento. A Lei n. 479/1999 limitou o prazo ao fim da audiência preliminar, com exceções que eu não analisarei aqui). L.vo 16 dic. 1999, n.479, Racc. Uff. 1999, vol. 13, 6496, publicado em Gazz. Uff. 18 dic. 1999, n. 296. A reforma mais recente no pattegiamento introduzida pela Lei 134/2003 não alterou este aspecto, e, como regra geral, as partes podem requerer a sua aplicação apenas até o fim da audiência preliminar. Confira art. 446.1 do C.P.P.I. As partes não podem requerer a aplicação do pattegiamento depois de seus arrazoados na audiência preliminar. 
não exceder cinco anos de prisão ${ }^{239}$. Se ao examinar o dossiê escrito o juiz não encontra nenhuma razão suficiente para absolver o acusado $^{240} \mathrm{e}$ considera a acusação e sentença proporcionais ao delito, aplicará a punição requerida ${ }^{241}$.

Apesar de mais parecido com o plea bargaining estadunidense do que o Absprache alemão há várias diferenças entre o patteggiamento e o plea bargaining estadunidense que refletem, em parte, a ambivalência dos

239 Art. 444.1 do C.P.P.I.. A limitação a até 5 anos de prisão foi introduzida pela lei em Junho de 2003. Confira L.vo 12 giu 2003., n.134, art.1, 1962, publicada em Gazz. Uff. 14 giu. 2003, n. 136 (daqui para diante apenas Lei 134/2003) (se o acordo ocorre entre crimes entre dois e cinco anos de prisão, alguns delitos como terrorismo e crime organizado estão excluídos). Antes desta última reforma, o acordo não poderia exceder a dois anos de prisão - após a redução da sentença - e desse modo foi limitada a crimes de menor gravidade. As duas justificativas dadas para ampliar a aplicação do pattegiamento a mais delitos foram a redução do número de processos do sistema de justiça criminal e a limitação do uso dos julgamentos adversariais para crimes mais graves. Confira Progetto di Legge - $\quad$ n. 1488, disponível em http:// camera.it/_dati/leg14/lavori/stampati/sk1500/relazion/1488.htm (última visita em 25 de novembro de 2003) (no arquivo do Harvard International Law Journal) (inicialmente propondo a ampliação do pattegiamento para sentenças de até 4 anos de prisão após a redução de um terço). Há várias sugestões de que a lei seria introduzida por razões políticas porque em seu art. 5 (não relacionado à extensão do pattegiamento às sentenças de até 5 anos de prisão) estabelecia que em processos em tramitação, o acusado poderia requerer uma suspensão e 45 dias para pensar sobre eventual requerimento de aplicação do pattegiamento. Esta suspensão foi usada por Cesare Previti - uma pessoa ligada a Silvio Berlusconi - no mesmo caso no qual Silvio Berlusconi era ele próprio acusado, mesmo que o caso não pudesse prosseguir enquanto ele estivesse no poder. Confira e.g. Berlusconi, processo sospeso sul "lodo" atti alla Consulta, LA REPUBBLICA, 30 de junho de 2003, na Politica, disponível em http://www.repubblica.it/online/politica/smestralciocinque/sospeso/sospeso.html.

(última visita em 26 de novembro de 2003). Desse modo, foi insinuado que este artigo 5 teria sido incluído para abafar o caso. Confira e.g. Vittorio Grevi, Doppio Blocco, DS MILANO, disponível em http://dsmilano.it/Pressroom/2003/07/cor3 0701 grevidoppio-blocco.htm (última visita em 25 de novembro de 2003).

240 Art. 444.2, 129 do C.P.P.I.

${ }^{241}$ Art. 444.2 do C.P.P.I. Se a sentença acordada é de até dois anos de prisão, o juiz pode substitui-la com uma pena alternativa como a semi-detenção (para sentenças de até dois anos de prisão), liberdade sob vigilância (para sentenças de até um ano de prisão) ou uma multa (para sentenças de até seis meses de prisão). Confira Lei 134/2003, op. cit. nota 239, art. 4.1(a). 
tradutores italianos com relação ao mecanismo introduzido por eles. Primeiramente, o patteggiamento é mais limitado em seu escopo e é menos flexível. Ele só pode ser aplicado aos casos nos quais a sentença não excede cinco anos de prisão após a redução da pena; e a redução da pena negociada pelas partes não pode ser maior do que um terço da pena cabível para o caso $^{242}$. Além disso, ao menos como foi originalmente concebida pelos tradutores, a negociação somente pode abarcar a sentença, não a acusação ou as acusações ${ }^{243}$. A decisão dos tradutores de estabelecer estas limitações mostra duas preocupações. De um lado, os tradutores eram ambivalentes em relação a este mecanismo de negociação porque estavam cientes dos problemas relativos ao devido processo ${ }^{244}$ que o plea bargaining estava gerando nos Estados Unidos ${ }^{245}$. Por outro lado, eles tinham consciência de que os atores jurídicos, com uma série de disposições internas inquisitoriais (e acostumados com uma distribuição inquisitória de poderes processuais), poderiam resistir ao instituto traduzido. Em razão disso, decidiram introduzi-lo somente para crimes de menor ofensividade e limitar a prática às negociações quanto à sentença ${ }^{246}$. Também, mesmo que uma reforma recente tenha ampliado os crimes sujeitos ao patteggiamento, a prática ainda não se aplica a todos os crimes ${ }^{247}$.

Em segundo lugar, no patteggiamento não há o guilty plea ou admissão explícita de culpa pelo réu ${ }^{248}$. Através do requerimento de aplicação da pena, o acusado abre mão do seu direito ao processo e pode estar implicitamente admitindo a sua culpa. Contudo, o juiz pode ainda decidir absolver o réu após examinar a prova colhida no dossiê escrito e antes de

${ }^{242}$ Art. 444.1 do C.P.P.I.

${ }^{243}$ Confira e.g. Pizzi \& Marafioti, op. cit. nota 223, na 22. Contudo, há alguns indicativos de que as alterações de acusação (charge bargains) podem ter sido introduzidas por práticos e aceitas pelos tribunais. Confira Cass. Pen. Sez. Cin. 7 de outubro de 1998, n. 12743.

${ }^{244}$ Lembre-se que a reforma teve uma clara inspiração garantista - do devido processo.

${ }^{245}$ Sobre estas críticas nos Estados Unidos confira a bibliografia citada na nota 173.

246 As alterações de acusação geralmente comprometem a verdade real mais do que os acordos sobre sentenças (sentencing bargains). Dessa maneira, a última seria muito mais aceitável desde uma perspectiva inquisitorial.

247 Sobre esta reforma Confira o art. 444.1 do C.P.P.I.

${ }^{248}$ Confira e.g. Pizzi \& Marafioti, op. cit. nota 223, na 23 
homologar o $\operatorname{acordo}^{249}$. Esta decisão de não introduzir uma admissão explícita de culpa no pattegiamento é outro reflexo da preocupação relativamente ao devido processo. Os autores temiam que uma admissão de culpa poderia minar a presunção de inocência garantida a todos os acusados pela Constituição Italiana ${ }^{250}$. Neste sentido, a ausência de uma explícita admissão de culpa faz com que o patteggiamento italiano seja mais similar às negociações do nolo contendere estadunidenses do que propriamente do guilty plea.

Em terceiro lugar, quando a acusação não aceita um acordo com o acusado, o último pode pedir ao juiz que analise, ao final do julgamento, os motivos alegados pela acusação para rejeitar o acordo, e assim dar-lhe a redução de um terço da pena ${ }^{251}$. Esta diferença reflete a influência do modelo da investigação oficial nas disposições internas dos tradutores ${ }^{252}$. Como explicado anteriormente, garantir benefícios aos acusados em troca de admissões de culpa - neste caso, admissões implícitas de culpa - não é desconhecido da estrutura italiana. O que é diverso, no entanto, é a negociação de uma sentença que desapossa o juiz de seus poderes sobre ela. Mesmo que o patteggiamento geralmente empodere as partes em detrimento dos poderes do juiz, esta regra indica que o juiz ainda conserva alguma quantidade de poderes na aplicação deste mecanismo e que o mecanismo não é apenas um procedimento negociado, mas também um benefício que pode ser concedido pelo juiz ao réu.

Por fim, a sentença prolatada através deste procedimento ${ }^{253}$ não gera efeitos civis ou administrativos ${ }^{254}$, o que aproxima novamente o

\footnotetext{
249 Arts. 444.2 e 129 do C.P.P.I.

${ }^{250}$ Confira Pizzi \& Marafioti, nota 223, na 23.

251 Art. 448.1 do C.P.P.I.
}

252 Como Pizzi \& Marafioti assinalaram, “a intenção do Código Italiano é tornar a redução da sentença disponível para todos os acusados que desejam acordar, com ou sem a concordância do Ministério Público. Este arranjo reflete a desconfiança tradicional dos regimes civil law, acerca dos poderes discricionários da acusação e o seu comprometimento com um tratamento uniforme dos acusados - que os acusados receberiam sentenças diferentes apenas devido ao capricho de um promotor é um anátema para a civil law." Pizzi \& Marafioti, op. cit. nota 223, na 22-23.

$253 \mathrm{O}$ veredito baseado em um pattegiamento é considerado "equivalente a uma veredito de culpabilidade" (art. 445.1-bis do C.P.P.I), embora não seja igual ao veredito após o 
patteggiamento do nolo contendere estadunidense mais do que o plea bargaining. Esta limitação dos efeitos legais do mecanismo, pode também refletir a ambivalência que os tradutores tinham em relação a ele, tanto por causa da preocupação com os problemas do devido processo como também pela influência do modelo de investigação sobre suas disposições internas.

Todavia, apesar de sua ambivalência, a tradução italiana do plea bargaining é fiel ao mecanismo estadunidense original, com relação ao fato de ser um procedimento através do qual a acusação e a defesa podem negociar ativamente penas, e ao juiz é atribuída uma posição relativamente passiva. Neste sentido, a adoção do patteggiamento tem tido, desde o início, um potencial efeito de americanização; caso aceito e internalizado pelos atores jurídicos italianos como um mecanismo de negociação, e acompanhado de outras reformas adversariais, o patteggiamento tem o potencial de dirigir as práticas processuais penais italianas rumo a um modelo de disputa, substituindo as disposições internas inquisitoriais dos atores jurídicos e a estrutura de interpretação e significado, e alterando a distribuição de poderes processuais.

Não causa surpresa, então, a existência de certa resistência a este novo procedimento, tanto por parte dos doutrinadores quanto dos tribunais ${ }^{255}$. Até o momento a mais importante reação dos tribunais foi a decisão 313/1990 da Corte Constitucional Italiana, prolatada um ano após o novo Código de Processo Penal Italiano introduzir o patteggiamento ${ }^{256}$.

procedimento regular. Isto explica os efeitos mais limitados que o veredito e a sentença baseados em um pattegiamento têm e mostra, uma vez mais, a desconfiança e a ambivalência que os reformadores possuíam acerca deste mecanismo.

${ }^{254}$ Art. 445.1 do C.P.P.I. A única exceção à esta regra é a de que a sentença acordada constitui res judicata para procedimentos disciplinares diante das autoridades públicas. Confira arts. 445.1-bis e 653.1 do C.P.P.I.

255 Entre as críticas da doutrina Confira FERRAJOLI, op. cit. nota 69 e FERRUA, op. cit. nota 182. Ambas as críticas citadas têm sua origem na defesa da subestrutura da investigação oficial por que ambos os pontos de vista apontam como os mecanismos de bargaining comprometem o ideal da verdade real. As suas críticas, contudo, inspiradas por preocupações para com o devido processo, uma vez que ambos os doutrinadores, compreendem a verdade - e o papel cognitivo do juiz - com uma proteção do acusado. Para uma sofisticada defesa desta concepção (garantista) de processo penal Confira FERRAJOLI, op. cit. nota 69.

${ }^{256}$ Corte cost. 26 giu. 1990, n.313, 96 Racc.Uff corts cost. 1990, 89. 
Nesta decisão, após declarar repetidamente que o poder judicial de controle sobre o acordo não era mera formalidade ${ }^{257}$, o Tribunal Constitucional declarou que o art 444.2 do Código de Processo Penal Italiano, que regulava o pattegiamento, era inconstitucional porque não dava expressamente ao juiz o poder de controlar a congruência entre a pena negociada pelas partes e a gravidade do crime, privando o juiz dos poderes de fazer valer o artigo 27.3 da Constituição Italiana, que estabelece que o objetivo da pena é a reabilitação do condenado ${ }^{258}$. Portanto, esta decisão tentou reafirmar e incrementar os poderes do juiz em detrimento daqueles das partes no que se refere ao patteggiamento.

Apesar desta reação, os atores jurídicos italianos têm usado freqüentemente o patteggiamento. Entre 1990 e 1998 o número de casos concluídos através deste procedimento perante a pretura ficou entre $17 \%$ e $21 \%$; e no caso do tribunale (com competência para todos os crimes, exceto os mais graves) ficou entre $34 \%$ e $42 \%{ }^{259}$. Agora que a aplicação do patteggiamento foi estendido aos crimes mais sérios ${ }^{260}$, os atores jurídicos italianos devem utilizá-lo ainda mais.

Isto indica que o modelo de disputa, entendido como uma estrutura de interpretação e significado, foi aceito e internalizado, ao menos até certo ponto, por um considerável número de atores jurídicos italianos. Além disso, como uma consequência da reforma do processo penal italiano iniciada em 1989, há outros indícios de que o modelo de disputa possui forte presença nos procedimentos criminais italianos. Isto inclui a possibilidade de a acusação e a defesa realizarem as suas próprias investigações preliminares, a organização do julgamento em um caso para a acusação e outro para a defesa, e a introdução do exame direto e cruzado, como mencionado anteriormente.

\footnotetext{
${ }^{257}$ Confira e.g. Id. na 97-98.

${ }^{258}$ Id. na $102-05$.

259 Para informações estatísticas de 1990 e 1991, Confira ISTITUTO CENTRALE DE STATISTICA, STATISTICHE GIUDIZIARIE; de 1992 - 1998, Confira ISTITUTO NAZIONALE DI STATISTICA, STATISTICHE GIUDIZIARIE PENALI. Eu não incluo estatísticas de 1989 por que o número total de processos é muito menor naquele ano do que em outros.

${ }^{260}$ Confira op. cit. nota 238 sobre a Legge, 12 giugno 2003, n. 134, art.1.
} 
Contudo, isto não quer dizer que o modelo de investigação oficial não tenha presença no processo penal italiano e nas predisposições individuais de um significativo número de atores jurídicos. Muitos juízes italianos, por exemplo, ainda acreditam que eles possuem o dever de assegurar que a verdade prevaleça e participam ativamente na investigação ${ }^{261}$. Ademais, os promotores e juízes italianos fazem parte do poder judiciário e ainda são treinados conjuntamente. Assim sendo, muitos promotores italianos se consideram, e são vistos desta forma por os juízes, como magistrados cujo papel é investigar a verdade e não apenas como partes de uma disputa ${ }^{262}$.

Analisar em detalhe estes embates, em particular a respeito do modelo de disputa e do modelo de investigação oficial, vai além do escopo deste artigo. O propósito desta parte foi mostrar como o plea bargaining estaunidense foi traduzido para o sistema italiano e os tipos de transformações que esta tradução pode ter produzido. Sob a perspectiva do debate da tese da americanização, o patteggiamento e outras reformas aproximaram as estruturas de interpretação e significado do modelo de disputa. Possivelmente em nenhum outro país de sistema civil law a estrutura atingiu tal status. Neste sentido, a reforma de 1989 parece ter deixado a Itália no meio do caminho entre os sistemas acusatório e inquisitorial.

\section{O “PLEA BARGAINING”ARGENTINO}

O sistema de plea bargaining argentino, dos quatro sistemas analisados, foi a tradução mais fiel do plea bargaining estadunidense. Entretanto, esta reforma representa a primeira de uma pequena série de reformas argentinas na direção do sistema adversarial. Uma vez que a estrutura inquisitorial de interpretação e significado, disposições internas e estrutura de poderes processuais do sistema argentino permanece predominante, é altamente improvável que esta reforma adversarial isolada

${ }^{261}$ Confira e.g. Grande, op. cit. nota 35 na 250-51.

${ }^{262}$ Sobre estas e outras resistências resultantes da estrutura da investigação oficial Confira Grande, op. cit. nota 35 . 
americanizará o processo penal argentino no sentido de direcionar as suas práticas processuais e culturais rumo ao modelo de disputa.

Em junho de 1997, a Argentina incorporou ao seu Código de Processo Penal Federal ${ }^{263}$ o chamado procedimiento abreviado ${ }^{264}$ com o intuito de acelerar procedimentos e reduzir o número de processos dos tribunais $^{265}$. Este mecanismo parece ter sido adotado principalmente por razões pragmáticas ao invés de ser o resultado de profundas influências culturais do sistema estadunidense sobre o sistema argentino, apesar destas influências, de fato, estarem presentes ${ }^{266}$. De qualquer forma, o plea bargaining estadunidense tem sido uma importante fonte para $O$

263 A Argentina é um Estado federal consistente de 23 províncias. Há um Código Penal para todas estas jurisdições. Mas cada província tem o seu próprio código de processo e seu próprio sistema de tribunais. O "Código Procesal Penal de la Nación" regula os procedimentos diante dos tribunais federais e dos tribunais da "Justicia Nacional en lo Criminal y Correccional" na cidade de Buenos Aires. Neste artigo eu me concentrarei neste procedimento.

${ }^{264} \mathrm{O}$ procedimiento abreviado é também chamado de juicio abreviado. Confira art. 431 do C.P.P.A.

265 Além destes dois objetivos, outras finalidades que foram consideradas durante as audiências do Congresso Argentino sobre este instituto foram a redução do número de prisões cautelares, reduzindo o custo dos processos criminais e racionalizando o uso dos recursos do processo penal e dar aos acusados a oportunidade de receber a redução em suas sentenças potenciais. Confira Wasylysyn, M. A, Trib. Oral Crim. No. 20, $8^{\text {a }}$ CUADERNOS DE DOCTRINA Y JURISPRUDENCIA PENAL 623, 628 (1998) (descrevendo a intervenção do deputado José I. Cafferata Nores no debate parlamentar de 23 de outubro de 1996). Confira também JOSÉ I. CAFFERATA NORES, CUESTIONES ACTUALES SOBRE EL PROCESO PENAL 143 (2 ed., 1998).

${ }^{266} \mathrm{O}$ sistema de justiça criminal estadunidense tem provocado uma profunda influência cultural sobre a Suprema Corte Argentina no que se refere aos direitos constitucionais no processo penal (busca e apreensão, o direito de não produzir prova contra si mesmo, regras de exclusão, doutrina dos frutos da árvore envenenada, etc). Para uma análise destes tipos de decisões pela Suprema Corte Argentina Confira ALEJANDRO CARRIÓ, GARANTÍAS CONSTITUCIONALES EM EL PROCESO PENAL (3 ED 1997). Relativamente à influência da Suprema Corte estadunidense sobre a Suprema Corte Argentina, Confira Carlos Ignacio Suárez Anzorena, Transnational Precedents: The Argentinian Case 26-40 (1998) (dissertação não publicada, Harvard Law School). Contudo, o sistema de justiça criminal dos Estados Unidos não tem sido influente como fora no caso italiano. O sistema italiano importou um número muito considerável de elementos do processo penal estadunidense, ao invés de apenas selecionar algumas partes dele. 
desenvolvimento da prática argentina. De acordo com o procedimiento abreviado, a acusação e a defesa podem chegar a um acordo a respeito da sentença a qualquer momento entre o indiciamento (information or indictment), no final da fase de investigação preliminar, e a data da determinação do julgamento ${ }^{267}$. Esta sentença negociada não pode ser maior do que seis anos de prisão ${ }^{268}$. Como parte do acordo, o acusado deve assumir a responsabilidade pelo crime e a sua participação como descrita no indiciamento ${ }^{269}$. O tribunal pode rejeitar o acordo se considerar a produção de outras provas necessária, ou se ele fundamentalmente discorda das acusações ${ }^{270}$. Contudo, se o tribunal aceitar o acordo ele deve chegar a um veredito baseado na prova coletada no dossiê escrito ${ }^{271}$. O tribunal pode ainda absolver o acusado, mas se condenado, a sentença do acusado não pode ultrapassar o que foi acordado pelas partes ${ }^{272}$.

De todas as traduções analisadas neste artigo, o procedimiento abreviado argentino parece ter sido a mais fiel ao plea bargaining estadunidense, ou mais especificamente, ao sentencing bargaining estunidense $^{273}$. A acusação e a defesa têm papeis ativos nas negociações sobre a sentença e admissões de culpa, enquanto o papel do tribunal é basicamente limitado ao do controle formal. Ademais, o procedimiento abreviado inclui uma admissão de culpa do acusado similar ao gulty plea. Além disso, uma vez que as partes podem chegar a um acordo sobre a sentença que não ultrapasse seis anos, o procedimiento abreviado pode ser aplicado a apenas alguns delitos graves ${ }^{274}$.

Entretanto, existem diferenças entre o procedimiento abreviado e o plea bargaining estadunidense que revelam como as decisões tomadas pelos tradutores argentinos e a estrutura inquisitorial preexistente argentina de

\footnotetext{
267 Art. 431 bis. 1 do C.P.P.A.

268 Id.

269 Art. 431 bis. 2 do C.P.P.A.

270 Art. 431 bis. 3 do C.P.P.A

271 Art. 431 bis. 5 do C.P.P.A

272 Id.

$273 \mathrm{O}$ plea bargaining estadunidense foi uma importante fonte para o desenvolvimento do procedimiento abreviado. Confira Wasylysyn, M.A op. cit. nota 265, na 628-29

$274 \mathrm{O}$ procedimento pode ser aplicado, por exemplo, para homicídio, estupro e roubo qualificado.
} 
interpretação e significado e a distribuição de poderes processuais transformaram a prática ${ }^{275}$. Em primeiro lugar, existe uma limitação temporal para que as partes cheguem a um acordo, tornando o processo inteiro menos flexível ${ }^{276}$. Segundo, no procedimiento abreviado, o juiz ainda pode absolver o acusado ${ }^{277}$. A admissão de culpa então, não é entendida exatamente como um guilty plea como nos Estados Unidos, mas como uma confissão que pode ser desconsiderada pelo tribunal, exemplificando a influência de uma estrutura inquisitorial preexistente de significado na prática. Terceiro, o tribunal deve respeitar como um limite superior, a

275 Aqueles que introduziram o procedimiento abreviado na Argentina foram os Professores Julio B. Maier (que incluiu um mecanismo semelhante em sua elaboração do Código de Processo Penal Federal, de 1986, o qual não foi sancionado pelo Congresso e no Código de Processo Penal Modelo para a América Latina) e José I. Cafferata Nores (professor universitário, primeiro ministro de justiça da Província de Córdoba e membro da Câmara dos Deputados quando o procedimiento abreviado foi sancionado). Ambos conceberam o instituto apenas para crimes sem gravidade. Por exemplo, no art. 371 do por ele elaborado Código de Processo Penal Federal, Prof. Maier concebeu-o para o tratamento de casos cuja sentença não era maior do que um ano de prisão, JULIO B. MAIER, EL PROYECTO DE CÓDIGO PROCESAL PENAL DE LA NACIÓN: PRESENTACIÓN DE JULIO B. MAIER, EXPOSICIÓN DE MOTIVOS, TEXTO COMPLETO DEL PROYECTO 764 (Cuadernos de la Revista Doctrina Penal, Series n. 01, 1987). Eles acreditaram que este mecanismo seria útil para gerenciar casos de menor gravidade de forma mais célere, mas ambos desconfiavam dele porque eles estavam conscientes de que o mecanismo implicava uma concepção de processo penal completamente diferente. Por exemplo, Maier disse expressamente que o mecanismo implicava uma concepção mais consensual e relativa de verdade. Confira Julio B. Maier, Mecanismos de Simplificación del Procedimiento Penal, in $8^{a}$ CUADERNOS DE DOCTRINA Y JURISPRUDENCIA PENAL, op.cit nota 269, na 433, 435 (1998). A desconfiança de Maier e Cafferata Nores acerca do instituto estava baseada nas preocupações para com o devido processo, por que eles conheciam as críticas que estas espécies de acordos geraram nos Estados Unidos e em outros lugares. Apesar de suas tentativas de introduzir os mecanismos apenas para casos de menor gravidade, o Congresso Argentino ampliou a sua aplicação para crimes relativamente graves.

${ }^{276}$ Confira Art. 431 bis. 1 do C.P.P.A.

$277 \mathrm{O}$ art. 431 bis. 5 do C.P.P.A. assevera que uma vez que acusação e defesa tenham chegado a um acordo, o tribunal mesmo assim deve decidir. Dessa maneira, é tecnicamente possível que o tribunal absolva o acusado após o acordo. Entretanto, a efetividade no que se refere a este tema é que os tribunais geralmente mantém a condenação. 
sentença acordada pelas partes ${ }^{278}$. Esta limitação não se aplica sempre no sentencing bargaining estadunidense, apesar da maioria dos juízes respeitá-la de facto $^{279}$. Quarto, em um processo com mais de um acusado, o mecanismo pode ser aplicado somente se aceito por cada um deles ${ }^{280}$. Isto mostra desconfiança a respeito do mecanismo desde uma perspectiva do devido processo $^{281}$.

Apesar dessas diferenças, o procedimiento abreviado é uma tradução fiel do plea bargaining estadunidense. Dessa forma, assume um modelo de disputa no sentido de que ambas as partes controlam o processo e de que o juiz possui um papel relativamente passivo. Nesse sentido, o procedimiento abreviado poderia ser considerado como um cavalo de Troia do modelo de disputa no modelo inquisitorial argentino de investigação oficial ${ }^{282}$. Se os atores jurídicos argentinos aceitarem e internalizarem este mecanismo, a reforma poderia potencialmente americanizar (ou adversarializar) o processo penal argentino.

O modelo de investigação oficial sempre foi predominante no processo penal argentino ${ }^{283}$. Então, não é surpreendente que alguns doutrinadores criticassem fortemente a introdução de um mecanismo tão claramente inspirado no modelo de disputa ${ }^{284}$. Todavia, advogados,

278 Id.

279 Para uma proposta de incorporar esta limitação no sistema estadunidense Confira Scott \& Stuntz, op. cit. nota 173, na 1953-57.

280 Art. 431 bis. 8 do C.P.P.A.

${ }^{281} \mathrm{O}$ requerimento de que todos os acusados devem aceitar participar dos acordos pode ter sido destinado a evitar o uso do procedimiento abreviado para finalidades investigativas, i.e, fazer um acusado depor contra outros acusados.

282 Para uma análise dos efeitos potenciais da incorporação do procedimiento abreviado na Argentina Confira Langer, op. cit. nota 26, na 124.

283 Para uma descrição em língua inglesa do processo penal federal argentino Confira Alejandro D. Carrió \&Alejandro M. Garro, Argentina, in CRIMINAL PROCEDURE, A WORLDWIDE STUDY 3 (Craig M. Bradley ed. 1999).

${ }^{284}$ Confira e.g. Franciso J. D’Álbora, El Proceso penal y los Juicios Abreviados, in 8a CUADERNOS DE DOCTRINA Y JURISPRUDENCIA PENAL, op. cit. nota 265, na 457, 463 (1998); Leopoldo Schiffrin, Corsi e Ricorsi de las Garantías Penales en la Argentina, in 8a CUADERNOS DE DOCTRINA Y JURISPRUDENCIA PENAL, op. cit. nota 265, na 481, 484 (1998). Como no exemplo italiano, parte desta crítica foi baseada nas preocupações para com o devido processo por conta de que vários 
promotores e juízes de uma forma geral aceitaram e usaram-no ${ }^{285}$. Por exemplo, no primeiro semestre de $2000,22 \%$ dos processos por crimes de menor gravidade na cidade de Buenos Aires foram resolvidos através do procedimiento abreviado; $52 \%$ dos processos criminais na mesma jurisdição forma concluídos da mesma forma ${ }^{286}$. Um dos principais motivos para essa ampla aceitação geralmente surge devido a fortes estímulos externos: entre 1990 e 2000, o número de infrações que ingressou no sistema de justiça criminal da cidade de Buenos Aires aumentou de 61.203 para $191.755(313 \%)^{287}$. Sob essa circunstância, qualquer mecanismo que conclua os processos criminais rapidamente seria bem-vindo, mesmo se ele estivesse em tensão com a estrutura preponderante de interpretação e significado, disposições internas e distribuição de poderes processuais.

Além da introdução do procedimiento abreviado há mais duas outras tendências que poderiam potencialmente direcionar o processo penal

doutrinadores reconheceram a crítica desde o devido processo que o plea bargaining recebeu nos Estados Unidos.

285 A resistência contra o procedimiento abreviado surgiu principalmente de membros de alguns tribunais. Na Argentina, tribunais de crimes graves e médios são compostos por três juízes. Existem algumas opiniões dissonantes dos membros destes tribunais asseverando que o procedimiento abreviado é inconstitucional porque um julgamento real é uma condição necessária para uma condenação criminal, que não pode ser substituída por um acordo entre acusação e defesa. Confira e.g. Dos Santos Amaral, M. Trib. Pen. Económico no 3, 8a CUADERNOS DE DOCTRINA Y JURISPRUDENCIA PENAL, op. cit. nota 264, na 613 (1998); Wazylysyn, m.a, OP. CIT. NOTA 264; Osorio Sosa, A. Trib. Oral Crim. No 23, 8a CUADERNOS DE DOCTRINA Y JURISPRUDENCIA PENAL, op. cit. nota 264, na 636 (1998). Além disso, alguns tribunais também declararam o procedimiento abreviado inconstitucional. Confira e.g. Yunez, R.D. Trib. Oral Crim. Fed. L.L 335.

286 MINISTERIO PÚBLICO FISCAL DE LA REPÚBLICA ARGENTINA, PROCURADORÍA GENERAL DE LA NACIÓN, INFORME ANUAL AL CONGRESO DE LA NACIÓN 2000 297-98, 285-86 (2000). Estas estatísticas se referem à fase de instrução (trial phase). Na fase de investigação preliminar, esta prática é totalmente insignificante, por isso a cobertura da fase de investigação preliminar não está incluída aqui.

${ }^{287}$ Confira Evolución de Hechos Delictuosos - 1990 a 1999 - Total País Por Província, Ministerio de Justicia, Seguridad y Derechos Humanos de la Nación Argentina em http://jus.gov.ar/polcrim/InfoDecada/infosnic2C33A.pdf (última visita em 2 de dezembro de 2003). 
argentino rumo ao modelo adversarial de disputa. Primeiro, o princípio da obrigatoriedade da ação penal não se aplicou no julgamento por vários $\operatorname{anos}^{288}$. Segundo, desde 1994 há uma distinção institucional muito clara entre promotores e juízes que pode contribuir para diferenciar ambos os papeis dentro do processo penal, uma condição que torna possível o modelo de disputa ${ }^{289}$.

Apesar de tudo, é importante não superestimar o significado destas mudanças, incluindo a introdução do procedimiento abreviado. Estas foram praticamente as únicas reformas introduzidas que poderiam potencialmente conduzir o sistema jurídico argentino na direção do modelo de disputa. No resto das práticas processuais penais argentinas encontradas na jurisdição federal e na jurisdição da cidade de Buenos Aires, a estrutura inquisitorial de interpretação e significado, disposições internas e distribuição de poderes processuais continua predominantemente ${ }^{290}$. Por exemplo, o modelo de investigação oficial pode ainda ser identificado no papel desempenhado pelo juiz, que ainda continua sendo o encarregado da investigação preliminar ${ }^{291}$; no processo, o

${ }^{288}$ Confira e.g. Tarifeño, F. CSJN (1995-B) L.L 32; García, J. A, CSJN (1995-B), L.L 31; Cattonar, J.P CSJN (1996-A) L.L 67. Para uma análise sucinta destas decisões Confira Julio B. Maier \& Máximo Langer, Acusación y Sentencia, in 1996/B NUEVA DOCTRINA PENAL 617 (1996). A Suprema Corte Argentina, contudo, voltou atrás em suas decisões sobre tais temas, e o princípio da obrigatoriedade agora se aplica durante a fase processual. Nota do tradutor: Depois da publicação deste artigo a Suprema Corte Argentina voltou atrás mais uma vez e o princípio da obrigatoriedade da ação penal não se aplica atualmente no julgamento.

${ }^{289}$ Confira o art. 120 da Constituição Argentina emendada pela Lei no 24.309, de 23 de agosto de 1994, B.O (estabelecendo que o Ministério Público não é parte do Executivo nem do Judiciário, mas um ramo separado do governo).

290 Diversas outras jurisdições argentinas introduziram reformas adversariais em seus processos penais durante a década de 90, incluindo a Província de Buenos Aires (1997) e a Província de Córdoba (1991). Contudo, estas reformas estão além dos objetivos deste artigo. Estas reformas eliminaram o juiz da investigação preliminar na maioria dos casos e colocou o promotor de justiça no encargo da investigação preliminar. Confira, e.g. Fabricio Guariglia \& Eduardo Bertoni, op. cit. nota 120, na 66-67. Entretanto, mesmo nestas jurisdições, o modelo da investigação oficial é ainda muito predominante e, dessa forma, estas reformas não modificam minhas principais conclusões.

${ }^{291}$ Confira art. 26 do C.P.P.A. 
tribunal pode decidir quais provas serão produzidas e em qual ordem ${ }^{292}$, além de possuir um papel ativo na oitiva das testemunhas, incluindo peritos $^{293}$. Com isso, apesar da similaridade do procedimiento abreviado com o sentencing bargaining estadunidense, o modelo de investigação oficial é muito mais presente na Argentina do que na Itália. Ao passo que o modelo de disputa apareceu nos procedimentos criminais federais argentinos, a sua presença ainda é pequena.

Desde a perspectiva da tese da americanização, o processo penal argentino não foi americanizado; o modelo de investigação oficial é ainda a concepção majoritária de processo penal nas práticas jurídicas argentinas. A principal razão para isso parece ser a de que, mesmo que a tradução do plea bargaining estadunidense tenha sido bastante fiel ao texto original, poucas reformas com efeito potencial de adversarialização foram introduzidas. As diferenças entre as culturas adversarial e inquisitorial são tão profundas que o efeito de americanização de uma única reforma adversarial como o procedimiento abreviado é suscetível de ser facilmente neutralizada. O cavalo de madeira foi levado para dentro dos muros do processo penal argentino, mas os soldados em sua barriga não foram suficientes para tomar Troia, ou mesmo parte substancial da cidade. Somente o tempo poderá dizer se novos cavalos de Troia aparecerão no futuro. ${ }^{294}$

\section{O “PLEA BARGAINING”FRANCÊS ${ }^{295}$}

\footnotetext{
292 Confira art. 356 do C.P.P.A.

293 Confira art. 389 do C.P.P.A.

${ }^{294}$ Nota do tradutor: o novo "Código Procesal Penal de la Nación Argentina”, Ley

27.063, foi aprovado em Dezembro de 2014, e tem uma estrutura muito mais adversarial, mais ainda no ha entrado em vigor.

295 O Ministro da Justiça da França, Dominique Perben apresentou um projeto de lei que está tramitando junto ao Congresso Francês (desde 24 de outubro de 2003), propondo reformas substanciais no processo penal francês. Confira projet de loi portant adaptation de la justice aux évolutions de la criminalité em http://www.assemblenat.fr/12/pdf/projets/pl0784.pdf (última visita em 3 de dezembro de 2003). Este projeto de lei, conhecido como "Projeto Perben" (projet de loi Perben) foi apresentado como uma tentativa de “adaptação da administração da justiça à evolução da criminalidade". Esta proposta inclui a possibilidade do acusado realizar acordos para crimes cuja pena é de até
} 
O plea bargaining francês ou composition pouco se assemelha ao modelo estadunidense. Ele se difere da prática estadunidense à medida que é muito mais uma ferramenta para deslocar processos dos procedimentos criminais formais do que uma forma de resolver os processos após eles ingressarem em tais procedimentos. Sendo assim, esta tradução do plea bargaining provavelmente não direcionará o processo penal francês, predominantemente inquisitorial, rumo ao sistema adversarial estadunidense.

Ao fim de junho de 1999, a composition foi introduzida nos artigos 41-2 e 41-3 do Código de Processo Penal Francês ${ }^{296}$, com o objetivo de diminuir a carga de processos nos tribunais ${ }^{297}$. Este mecanismo foi considerado homólogo ao plea bargaining estadunidense porque abria

cinco anos de prisão. Uma vez que se trata de um projeto que até o momento ainda não foi aprovado, eu não a analisarei em detalhe neste artigo. (Nota do tradutor: este projeto foi adoptado por la lei "Perben II" de 9 de Março de 2004. Confira Art. 495-7 a 495-16 do C.P.P.F.). Outra tentativa de introduzir um mecanismo semelhante aos guilty pleas aconteceu no final da década de 80 e início da década de 90, quando uma Comissão do Ministério da Justiça Francês - geralmente conhecida como Comissão Delmas-Marty propôs a introdução de um mecanismo similar ao guilty plea estadunidense, apesar dela rejeitar especificamente a introdução do plea bargaining. Confira COMISSION JUSTICE PÉNALE ET DROITS DE L'HOMME, LA “MISE EN ÉTAT” DES AFFAIRES PÉNALES (1991). Duas das razões pelas quais os atores jurídicos franceses rejeitaram estas propostas foram que eles vislumbraram-nas como estrangeiras e a ligação destes atores ao existente sistema inquisitorial (Confira Denis Salas, La justice entre les deux "corps" de la democracie, in LA JUSTICE, UNE RÉVOLUTION DÉMOCRATIQUE 20 (Denis Salas ed., 2001). Para uma breve análise da proposta da Comissão Delmas-Marty quanto aos guilty pleas, Confira Tulkens, op. cit. nota 181, na 672.

${ }^{296}$ Lei no 99-515 de 23 de Junho de 1999, J.O. 24, 1999, p. 9207. A antecessora da composition pénale foi a injonction pénale, transformada em lei em 22 de dezembro de 1992. Entretanto, em 2 de fevereiro de 1995 a Corte Constitucional (Conseil Constitutionne) declarou a injonction inconstitucional dizendo que ela era contrária à presunção de inocência e que dava ao acusador o poder de julgar casos e impor sanções que deveriam ser impostas pelos tribunais. Confira MERLE \& VITU, op.cit nota 112, na 396.

297 Confira PHILIPPE CONTE \& PATRICK MAISTRE DU CHAMBON, PROCÉDURE PÉNALE, 3 -4 (3 ed. 2001); MERLE \& VITU, op. cit. nota 112, na 395. 
espaço para negociações entre a acusação e a defesa ${ }^{298}$. De acordo com a composition, antes do início dos procedimentos formais, a acusação pode oferecer ao acusado a opção de deslocar o seu processo de um procedimento criminal padrão em troca de uma admissão de culpa e o cumprimento de uma condição como o pagamento de uma multa, a entrega de quaisquer objetos usados para cometer o crime (ou obtidos através do crime), abrir mão da sua licença para dirigir ou para caçar por certo período de tempo, prestar serviço comunitário e/ou reparar o dano causado à vítima ${ }^{299}$. Se o acusado aceitar a oferta, o promotor requererá a homologação judicial $^{300}$. Se o acusado não aceita o oferta ou não cumpre os termos do acordo, o promotor pode simplesmente dar início aos procedimentos formais ${ }^{301}$.

${ }^{298}$ MERLE \& VITU, op. cit. nota 112, na 396; Cedras, op. cit. nota 182, na 156-57; JeanClaude Magendie, L'américanization du droit ou la création d'um mythe, 45 ARCHIVES DE PHILOSOPHIE DU DROIT 13, 18-19 (R. Sève et al eds., 2001). Há outros mecanismos no processo penal francês que abrem espaço para negociações entre acusador, acusado e até mesmo a vítima e o juiz, como a médiation pénale, correctionalisation e comparution inmédiate. Confira Tulkens, op. cit. nota 181, na 660-61, 672-73. Eu não os analisarei aqui e, no que é de meu conhecimento, eles não foram inspirados pelo ou considerados análogo ao plea bargaining. Para análises do papel da negociação não apenas no direito penal mas também em outros campos jurídicos Confira, genericamente, os artigos incluídos em DROIT NÉGOCIÉ, DROIT IMPOSÉ (Philippe Gérard et al ed., 1996).

299 Art. 41-42 do C.P.P.F. Para uma análise detalhada deste mecanismo, Confira MINISTÈRE DE LA JUSTICE, Circulaires de la direction des Affaires criminelles et des Grâces, 83, BULLETIN OFFICIEL DU MINISTÈRE DE LA JUSTICE 25 (2001), disponível em http://www.justice.gouv.fr/actua/bo/dacg83c.htm) (última visita em 25 de novembro de 2003). A proposta não pode ser feita quando o acusado estiver preso. O acusador ou seu representante deve informar o acusado de seu direito de ser assistido por um advogado.

300 Tanto o acusado quanto a vítima podem solicitar uma audiência para o juiz antes dele decidir sobre o acordo. Contudo, esta audiência não é realizada caso não haja solicitação expressa. Confira arts. 41-42 do C.P.P.F. Como a composition foi introduzida como uma forma de lidar mais efetivamente com os crimes de menor gravidade entende-se que uma audiência com o acusado e/ou a vítima antes de validar o acordo é excepcional. MINISTÈRE DE LA JUSTICE, op. cit. nota 299, na 96.

${ }^{301}$ Enquanto as condições do acordo estiverem sendo cumpridas, a regra das limitações é suspensa. 
A composition somente pode ser aplicada a certos delitos especificamente listados no código francês, como agressão simples, ameaças, roubo simples, dano, calúnia, injúria ou difamação, maus tratos a animais, posse de certas armas, ou dirigir embriagado, entre outros ${ }^{302}$. Em suma, é um mecanismo a ser aplicado apenas em infrações mais leves ${ }^{303}$.

Neste ponto já é possível perceber que a composition francesa pouco se parece com o plea bargaining ${ }^{304}$. Aqui, de novo, fica claro como é inadequada a ideia do transplante jurídico para capturar o fenômeno da circulação de ideias e práticas jurídicas. Existem algumas similaridades entre os procedimentos do plea bargaining estadunidense e a composition: ambos podem incluir negociações entre o promotor e o acusado e este deve admitir a sua culpa como parte do acordo. Isto, contudo, é o alcance de suas semelhanças.

As diferenças entre o plea bargaining estadunidense e a composition são significativas. Primeiro, enquanto a aplicação do plea bargaining encurta os procedimentos criminais regulares, no sentido de que o julgamento não é necessário para determinar a culpa ou inocência, a aplicação da composition

302 Arts. 41-42 do C.P.P.F; MINISTÈRE DE LA JUSTICE, op. cit. nota 299, na 69-70. 303 MINISTÈRE DE LA JUSTICE, op. cit. nota 299, na 68. Além de propor a introdução de um novo mecanismo semelhante ao guilty plea estadunidense (reconnaissance préalable de culpabilité), Confira Perben, op. cit. nota 302, o "Projeto Perben" também propõe uma ampliação da composition para todos os crimes com até cinco anos de prisão. Confira Dominique Perben, projet de loi portant adaptation de la justice aux évolutions de la criminalité, tit II, ch. 1, sec 2 ("Dispositiions relatives à la compositiion pénale et aux autres procédures alternatives aux poursuites") (propondo um novo texto para o art. 41-42 do Código de Processo Penal da França) disponível em http://www.assemblenat.fr/12/pdf/projets/pl0784.pdf (última visita em 3 de dezembro de 2003). (Nota do tradutor: este projeto foi adoptado por la lei "Perben II" de 9 de Março de 2004. Confira Art. 41-2 do C.P.P.F.).

${ }^{304}$ O mecanismo proposto pelo "Projeto Perben", Confira op. cit. nota 299, é muito mais semelhante ao plea bargain americano porque inclui negociações entre a acusação e a defesa no que se refere à punição em troca de uma admissão de culpa nos procedimentos penais formais, assim como os tribunais possuem um papel limitado em tais acordos. Confira Dominique Perben, Projet de loi portant adaptation de la justice aux évolutions de la criminalité, ch.IV, sec.1, art. 61, sec. VIII ("De la comparution sur reconnaissance préalable de culpabilité) em http://www.assemble-nat.fr/12/pdf/projets/pl0784.pdf (última visita em 3 de dezembro de 2003). Se adotado, o "Projeto Perben" poderia potencialmente produzir um "efeito de americanização" que a composition não parece ter. 
evita diretamente tais procedimentos ${ }^{305}$. Segundo, enquanto a aplicação do plea barganining estadunidense significa que o acusado é considerado juridicamente culpado e então punido, a aplicação da composition não possui o efeito jurídico de um veredito de culpabilidade. Se o acusado cumpre as condições do acordo, o processo é extinto com a produção de coisa julgada material (dismissed with prejudice) ${ }^{306}$. Terceiro, no plea bargaining o promotor está numa igual posição negocial com a defesa. $\mathrm{Na}$ composition, o promotor não negocia com um igual mas está mais próximo de um agente da condicional que exerce controle sobre uma pessoa que violou a lei e pode cometer novos delitos no futuro. $\mathrm{O}$ acusado deve aceitar a oferta do promotor e admitir a sua culpa, não como uma parte que pode encerrar a disputa com o seu consentimento, mas como parte de seu próprio processo de neutralização, reabilitação e reparação da vítima ${ }^{307}$.

Através da composition os legisladores franceses traduziram o plea bargaining estadunidense não de uma estrutura processual adversarial de significado para uma inquisitorial, mas de um sistema adversarial para o que pode ser chamado de "modelo despenalizador". Na segunda metade do século XX, diversos países europeus testemunharam um movimento rumo à despenalização dos delitos menos graves ${ }^{308}$. De acordo com o modelo despenalizador, o sistema de justiça criminal regular, com suas penas de prisão, é demasiadamente duro e ao mesmo tempo ineficaz no tratamento da criminalidade menos grave. Multas, trabalho comunitário e reparação à vítima, dentre outras sanções foram propostas para substituir a prisão. Certo número de sistemas alternativos também foram criados para

\footnotetext{
305 Confira MERLE \& VITU, op. cit. nota 112, na 396.

306 Art. 41-42 do C.P.P.F.

307 A admissão de culpa pelo acusado tem um caráter pedagógico. MINISTĖRE DE LA JUSTICE, op. cit. nota 299, na 65.

308 Para uma análise do desenvolvimento deste modelo na Europa Confira MIREILLE DELMAS-MARTY, LES GRANDS SYSTÈMES DE POLITIQUE CRIMINELLE 159-63, 278-93 (1992). Nos Estados Unidos há certas tendências na mesma direção. Por exemplo, a introdução de mecanismos de diversion nos últimos anos para lidar com drogas, violência doméstica e casos envolvendo menores poderiam ser considerados parte de um desenvolvimento similar. Para uma análise da expansão da diversion nos Estados Unidos nas últimas três décadas. Confira, por exemplo, MILLER ET AL, op. cit., nota 79, na 663-65.
} 
permitir que tribunais administrativos, civis e de mediação resolvam casos tradicionalmente de competência dos processos criminais ${ }^{309}$.

O modelo despenalizador não tenta abolir ou substituir por completo o sistema de justiça criminal e seus procedimentos. Ao invés disso, ele tenta limitar o seu alcance atuando de uma forma complementar ${ }^{310}$. Ele não adota nenhum tipo específico de procedimento. Ele pode funcionar confortavelmente em procedimentos administrativos relativamente inquisitoriais, em procedimentos civis estruturados de acordo com o modelo adversarial de disputa ou em programas de mediação. O modelo despenalizador visa a retirar as infrações menos graves dos procedimentos criminais formais e evitar o recurso à prisão e ao mesmo tempo mantendo certo controle formal sobre estes processos; assim, há inúmeros procedimentos através dos quais estes objetivos podem ser atingidos.

A composition pode ser incluída no modelo despenalizador ${ }^{311}$. Desta forma, mesmo que a composition seja finalmente bem sucedida e largamente utilizada ${ }^{312}$, é improvável que ela direcionará os regulares procedimentos criminais inquisitoriais franceses na direção do modelo de disputa; ao invés, é mais provável o fortalecimento do modelo despenalizador na França. Primeiro, como analisado anteriormente, a composition em, mesmo que inspirada no plea bargaining, não assume o modelo de disputa, principalmente porque não trata o acusado como uma parte igual à

${ }^{309}$ Confira e.g. Tulkens, nota 181, na 648-49.

310 A Professora Delmas-Marty faz uma distinção entre despenalização e descriminalização. Enquanto a primeira serviria como um recurso complementário ao sistema de justiça criminal, o segundo se apresentaria como uma alternativa a ele. Confira DELMAS-MARTY, supra, nota 308, na 278-279.

311 A composition é parte do modelo despenalizador porque tenta retirar determinados casos do sistema de justiça criminal regular, mantendo estes casos sob um controle de justiça criminal mais moderado. Sobre o duplo objetivo da composition Confira CONTE \& MAISTRE DU CHAMBON, supra, nota 297, na 209.

312 Até o momento, as provas empíricas mostram que a composition tem sido utilizada moderadamente. Há estatísticas oficiais sobre o uso desta prática apenas no ano de 2001. De 893.373 processos, a composition foi usada em apenas 1.511 (0,17\%). Confira MINISTÈRE DE LA JUSTICE, ANNUAIRE STATISTIQUE DE LA JUSTICE, 2003, disponível em http: //www.justice.gouv.fr/publicat/m-Activparquest.pdf (última visita em 25 de novembro de 2003). 
acusação. Neste sentido, a composition não parece ter um efeito potencial de adversarialização ou americanização. Segundo, mesmo que tivesse, o próprio fato de a composition não ser aplicada nos procedimentos criminais regulares também tornaria o potencial de guiar o modelo de investigação oficial francês para aquela direção, muito improvável.

A tradução do plea bargaining para a França, então, não parece representar um desafio ao seu predominante modelo de investigação oficial de processo penal, bem menos desafiadora do que foi a introdução do procedimiento abreviado na Argentina.

\section{CONCLUSÃO: FRAGMENTAÇÃO NA CIVIL LAW?}

Nas últimas quatro partes eu demonstrei como nos últimos anos as jurisdições civil law da Alemanha, Argentina, França e Itália traduziram o plea bargaining estadunidense em suas jurisdições de diferentes formas e como estes mecanismos, em suas interações com os atores e práticas jurídicas do sistema de justiça criminal receptor e outros fatores, podem estar produzindo diferentes resultados em cada uma destas jurisdições.

No caso da Alemanha, o Absprache trouxe o desenvolvimento de um novo sistema processual penal - o modelo do juiz-gestor baseado na cooperação - que agora coexiste e desafia o tradicional modelo inquisitorial alemão de investigação oficial. No caso da Itália, o pattegiamento, atuando em conjunto com outras reformas, introduziu o modelo de disputa que agora representa um sério desafio ao modelo tradicional e predominante de investigação oficial. No caso da Argentina, o procedimiento abreviado introduziu e reforçou elementos do modelo de disputa no processo penal federal, apesar do modelo de investigação oficial ainda ser predominante, muito mais do que na Itália. Finalmente, no caso da França, a composition pode reforçar o modelo despenalizador e reduzir o número de casos processados através do modelo da investigação oficial. Contudo, este último modelo é ainda predominante nos procedimentos criminais regulares.

Esta análise demonstra o que podem ser consideradas importantes diferenças entre estas jurisdições e que estas diferenças constituem algo 
novo no mundo civil law que durante muito tempo foi uma cultura jurídica relativamente homogênea. Embora existissem diferenças entre as jurisdições civil law e desafios à cultura processual inquisitorial em cada uma delas, em todas as quatro jurisdições examinadas aqui, o processo penal era ainda majoritariamente conceitualizado em torno do modelo da investigação oficial. É sobre esta profunda concepção de processo penal comum que estas quatro jurisdições civil law estão começando a se diferenciar.

Assim sendo, enquanto as influências estadunidenses sobre o mundo civil law são inegáveis, ao menos nos procedimentos criminais formais, elas não estão produzindo uma forte americanização ou adversarialização da civil law, mas ao contrário, a sua fragmentação. Esta fragmentação é devida, ao menos em parte, ao fato de que os sistemas inquisitoriais "traduziram" as influências estadunidenses adversariais de diferentes maneiras. Em suas interações com o processo penal receptor, cada mecanismo traduzido tem o potencial de transformar e ser transformado pelo sistema inquisitorial de formas diferentes. Como resultado os procedimentos criminais da tradição civil law começaram um processo de diferenciação.

Este fenômeno tem conseqüências importantes no debate sobre a tese da americanização. Embora apoie a versão fraca da tese da americanização na qual justificam-se as influências adversariais sobre os sistemas inquisitoriais, ele deveria também conduzir a uma revisão e a uma mais concreta e sutil análise da versão forte desta tese. Como demonstrado, as influências do sistema estadunidense sobre outros sistemas jurídicos podem produzir diferentes efeitos em cada um deles, dependendo das decisões tomadas pelos tradutores jurídicos, quantos poderes eles precisavam ter para promover suas reformas, quanta resistência havia contra eles, etc. Além disso, este estudo demonstra que a americanização não é um jogo de tudo ou nada. Em outras palavras, as práticas do sistema jurídico receptor podem mover na direção do sistema estadunidense em um nível do procedimento, mas não em outro, como no caso do sistema alemão, no qual o Absprache é incapaz de promover o modelo americano de disputa, mas pode promover uma concepção mais 
consensual e relativa da verdade, como aquela que predomina no sistema estadunidense.

Existem dois pontos da argumentação que merecem serem ressaltados. Primeiro, eu discuti algumas das insuficiências da metáfora do transplante jurídico como um meio de compreensão da circulação das instituições jurídicas entre sistemas jurídicos e propus a metáfora da tradução jurídica como um dispositivo heurístico alternativo para abordar estas questões. Alguns podem considerar esta discussão sobre metáforas como um jogo de palavras desprovido de valor substancial, mas isso seria um erro. As metáforas são importantes porque nós pensamos através delas e porque elas realçam diferentes aspectos da realidade. O principal conceito que eu procuro enfatizar através da metáfora da tradução jurídica é o de que as práticas e instituições jurídicas podem ser transformadas quando traduzidas entre sistemas jurídicos, tanto pelas decisões dos reformadores (tradutores) quanto pelas diferenças estruturais entre os sistemas jurídicos original e receptor (linguagens). Além disso, a instituição jurídica traduzida pode produzir uma cadeia de mudanças - até mesmo inesperadas como no caso do Absprache alemão - no sistema jurídico receptor. Dado que estas transformações foram negligenciadas por vários estudiosos e agentes públicos, a metáfora da tradução é útil para ressaltar essas mudanças.

Segundo, eu demonstrei que os sistemas adversarial e o inquisitorial podem ser analisados não apenas como duas formas diferentes de distribuição de poderes e responsabilidades entre os principais atores do processo penal, mas também como duas culturas processuais - duas concepções diferentes de como casos penais deveriam ser julgados e processados. Mesmo que estas culturas processuais não sejam inteiramente homogêneas, algumas concepções de processo penal claramente prevaleceram nos Estados Unidos e nas quatro jurisdições civil law aqui examinadas. Eu propus um novo quadro teórico para analisar essas culturas processuais predominantes e usei-o para explicar algumas das transformações pelas quais passou o plea bargaining após a sua tradução para as jurisdições civil law da Alemanha, Itália, França e Argentina. A conceitualização dos sistemas adversarial e inquisitorial também nos ofereceu um claro eixo de referência para avaliar se nossas quatro 
jurisdições civil law estão se movendo ou se moveram em direção ao sistema estadunidense.

A conceitualização dos sistemas adversarial e inquisitorial como culturas processuais também é importante por outras razões. O debate sobre a americanização do direito é, em grande medida, um debate sobre culturas jurídicas. Em outras palavras, é um debate sobre como o direito é compreendido, pensado e praticado em diferentes jurisdições e também sobre como certas concepções dos fenômenos jurídicos que prevalece nos Estados Unidos podem triunfar sobre outras concepções. Uma conceitualização teórica dos sistemas adversarial e inquisitorial tal como oferecida neste artigo é, portanto, necessária para participar plenamente de um debate como este. 